This report has been reproduced from the best available copy. Available in paper copy and microfiche.

Number of pages in this report: 113

DOE and DOE contractors can obtain copies of this report from:

Office of Scientific and Technical Information

P.O. Box 62

Oak Ridge, TN 37831

(615) 576-8401

This report is publicly available from:

National Technical Information Service

Department of Commerce

5285 Port Royal Road

Springfield, VA 22161

(703) 487-4650 


\section{DISCLAIMER}

Portions of this document may be illegible in electronic image products. Images are produced from the best available original document. 


\title{
LONG-TERM SURVEILLANCE PLAN FOR THE \\ SHIPROCK DISPOSAL SITE, SHIPROCK, NEW MEXICO
}

September 1994

This document supersedes document number UMTRA-DOE/AL-350204.0000

\author{
Prepared for \\ U.S. Department of Energy \\ UMTRA Project Office \\ Albuquerque, New Mexico \\ Prepared by \\ Jacobs Engineering Group Inc. \\ Albuquerque, New Mexico \\ DISCLAIMER
}

This report was prepared as an account of work sponsored by an agency of the United States Government. Neither the United States Government nor any agency thereof, nor any of their employees, makes any warranty, express or implied, or assumes any legal liability or responsibility for the accuracy, completeness, or usefulness of any information, apparatus, product, or process disclosed, or represents that its use would not infringe privately owned rights. Reference herein to any specific commercial product, process, or service by trade name, trademark, manufacturer, or otherwise does not necessarily constitute or imply its endorsement, recommendation, or favoring by the United States Government or any agency thereof. The views and opinions of authors expressed herein do not necessarily state or reflect those of the United States Government or any agency thereof. 
This is a controlled document. The holder of the document will be notified of page/content changes and will be responsible for inserting all changes to keep the document current. 
TABLE OF CONTENTS

Section

Page

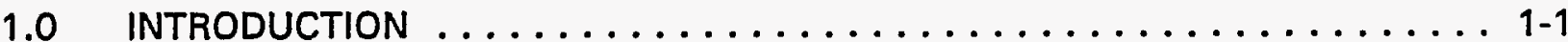

1.1 Background ........................... 1-1

1.2 Licensing process ......................... 1-2

1.3 Long-term surveillance plan . . . . . . . . . . . . . . . 1-2

2.0 FINAL SITE CONDITIONS ........................ 2-1

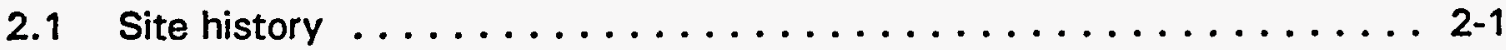

2.2 Site description $\ldots \ldots \ldots \ldots \ldots \ldots \ldots \ldots \ldots \ldots \ldots \ldots \ldots \ldots \ldots . \ldots \ldots$

2.2.1 Description and location of disposal site area $\ldots \ldots \ldots \ldots . \ldots 2-2$

2.2 .2 Neighboring land uses . . . . . . . . . . . . . . . . 2-6

2.2 .3 Disposal site access and security ................ 2-6

2.2 .4 Disposal cell design ..................... 2-8

2.2.5 Design features to be monitored .............. 2-10

3.0 SITE DRAWINGS AND PHOTOGRAPHS $\ldots \ldots \ldots \ldots \ldots \ldots \ldots \ldots \ldots \ldots$

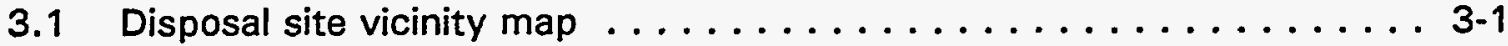

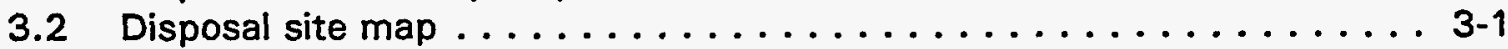

3.3 Disposal site as-built drawings . . . . . . . . . . . . . 3-2

3.4 Site baseline photographs . . . . . . . . . . . . . . . . . 3-2

3.5 Site aerial photographs ........................ $3-2$

3.6 Site inspection photographs ......................... 3 .2

3.6.1 Features to be photographed ................ 3-4

4.0 PERMANENT SITE SURVEILLANCE FEATURES . . . . . . . . . . . . 4-1

4.1 Survey monuments ...................... 4 .1

4.2 Boundary monuments ........................ 4-1

4.3 Site markers ............................ . . . . . . . .

4.4 Entrance and perimeter signs ..................... $4-5$

4.5 Settlement plates .......................... $4-5$

4.6 Additional site surveillance features . . . . . . . . . . . . . 4-5

4.6.1 Erosion control markers .................. 4-5

4.6.2 Reference posts ................... 4-12

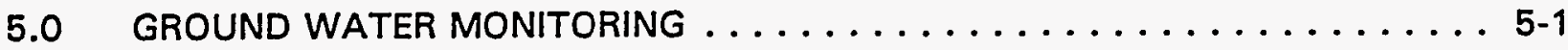

5.1 Ground water characterization . . . . . . . . . . . . . . 5-1

5.1 .1 Hydrostratigraphy .................... 5-1

5.1 .2 Background ground water quality .............. 5-2

5.2 Ground water monitoring network ................... 5-2

6.0 SITE INSPECTIONS ........................... $6-1$

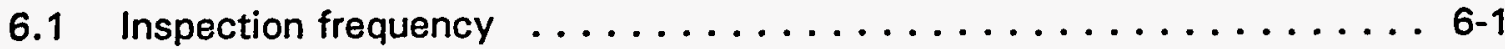

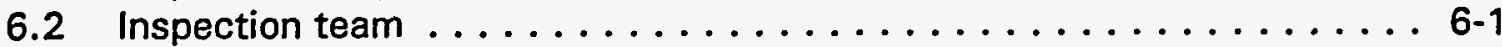

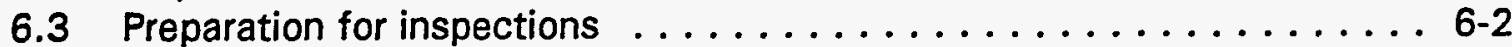


TABLE OF CONTENTS (Continued)

Section

Page

6.4 Site inspection and inspection checklist $\ldots \ldots \ldots \ldots \ldots \ldots \ldots \ldots$

6.4 .1 Off-site areas ...................... 6-3

6.4 .2 On-site areas ..................... 6-3

6.4 .3 Modifying processes .................... 6-4

6.5 Site inspection map ...................... 6-5

6.6 Reporting requirements .....................6-5

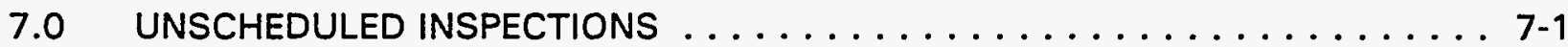

7.1 Follow-up inspections ...................... $7-1$

7.2 Contingency inspections ....................

8.0 CUSTODIAL MAINTENANCE AND REPAIR . . . . . . . . . . . . $8-1$

8.1 Planned maintenance . . . . . . . . . . . . . . . . 8 8 .1

8.2 Unscheduled maintenance or repair ................. $8-1$

8.3 Certification and reporting requirements $\ldots \ldots \ldots \ldots \ldots \ldots \ldots . \ldots . \ldots$

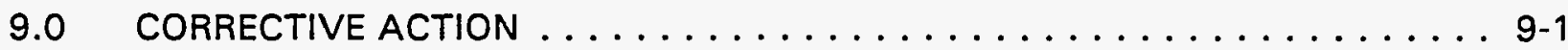

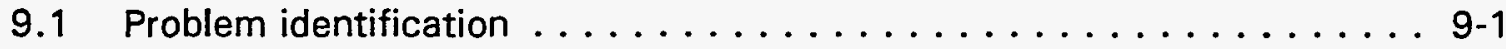

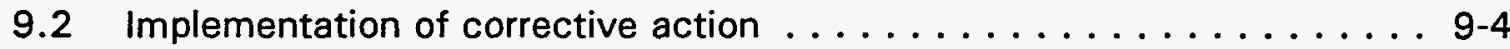

9.3 Certification and reporting requirements $\ldots \ldots \ldots \ldots \ldots \ldots$

10.0 RECORD KEEPING AND REPORTING REQUIREMENTS . . . . . . . . . . 10-1

10.1 Records . . . . . . . . . . . . . . . . . . . . . 10-1

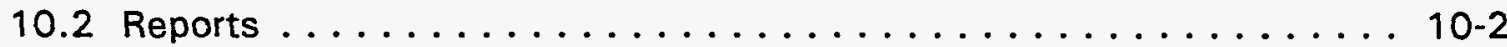

11.0 EMERGENCY NOTIFICATION AND REPORTING $\ldots \ldots \ldots \ldots \ldots \ldots \ldots$

11.1 Agency agreements . . . . . . . . . . . . . . . 11-1

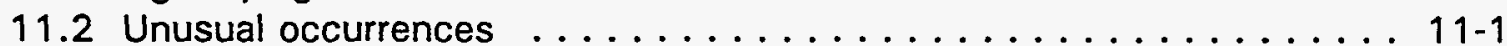

11.3 Earthquakes ........................... 11-2

11.4 Meteorological events . . . . . . . . . . . . . . 11-2

12.0 QUALITY ASSURANCE ....................... 12-1

12.1 Ground water monitoring . . . . . . . . . . . . . . . . 12-1

13.0 PERSONNEL HEALTH AND SAFETY $\ldots \ldots \ldots \ldots \ldots \ldots \ldots \ldots \ldots \ldots \ldots$

13.1 Health and safety . . . . . . . . . . . . . . . . . . 13-1

13.2 Reportable incidents . . . . . . . . . . . . . . . 13-2

14.0 LIST OF CONTRIBUTORS $\ldots \ldots \ldots \ldots \ldots \ldots \ldots \ldots \ldots \ldots$

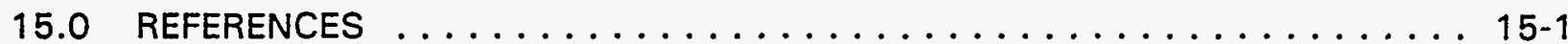


TABLE OF CONTENTS (Concluded)

ATTACHMENT 1 NRC CONCURRENCE AND LICENSING DOCUMENTATION

ATTACHMENT 2 SITE OWNERSHIP/CUSTODY DOCUMENTATION

ATTACHMENT 3 PERMANENT SITE FILE INDEX

ATTACHMENT 4 SITE INSPECTION PHOTO LOG

ATTACHMENT 5 INITIAL SITE INSPECTION CHECKLIST

ATTACHMENT 6 AGENCY NOTIFICATION AGREEMENTS 


\section{LIST OF FIGURES}

Figure

Page

2.1 Area map, Shiprock, New Mexico, disposal site . . . . . . . . . . . . . . 2-3

2.2 Disposal site location, Shiprock, New Mexico . . . . . . . . . . . . . . . . . 2-4

2.3 Physiographic setting, Shiprock, New Mexico, disposal site . . . . . . . . . . . 2-5

2.4 Land use in the vicinity of Shiprock, New Mexico, site, $1993 \ldots \ldots$. . . . . . 2-7

2.5 Disposal cell cover cross section, Shiprock, New Mexico, disposal cell . . . . . 2-9

4.1 Typical survey monument, Shiprock, New Mexico, disposal site . . . . . . . . 4-2

4.2 Typical boundary monument/erosion control marker, Shiprock, New Mexico, disposal site .............................. 4-4

4.3 Site marker - SMK-1 located at site entrance, Shiprock, New Mexico, disposal site .............................. 4-6

4.4 Site marker - SMK-2 located at crest of disposal cell, Shiprock, New Mexico,

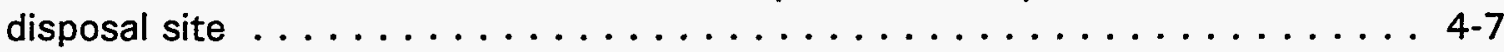

4.5 Site marker incised message, Shiprock, New Mexico, disposal site . . . . . . . 4-8

4.6 Entrance and perimeter signs, Shiprock, New Mexico, disposal site . . . . . . 4-9

4.7 UMTRA Project settlement plate, Shiprock, New Mexico, disposal site . . . . 4-10

5.1 Bedrock surface contours on terrace . . . . . . . . . . . . . 5-3

5.2 Representative cross section, Shiprock, New Mexico, site . . . . . . . . . . . 5-4

9.1 Corrective action, UMTRA Project long-term surveillance program . . . . . 9-2

9.2 Key elements in the corrective action process $\ldots \ldots \ldots \ldots \ldots \ldots . \ldots . \ldots$

\section{LIST OF PLATES}

$1 \quad$ Shiprock disposal site map

\section{LIST OF TABLES}

Table

Page

2.1 Shiprock disposal site access key holders $\ldots \ldots \ldots \ldots \ldots \ldots \ldots \ldots$

3.1 Aerial photography specifications for the Shiprock disposal site $\ldots \ldots \ldots$. . . 3

4.1 Survey coordinates and elevations for survey monuments and erosion control markers at the Shiprock, New Mexico, disposal site . . . . . . . . . . 4-3

4.2 Survey coordinates and elevations as of October 6,1986 , for settlement plates at the Shiprock, New Mexico, disposal site 


\section{LIST OF ACRONYMS}

\begin{tabular}{|c|c|}
\hline Acronym & Definition \\
\hline ac & acre \\
\hline $\mathrm{cm}$ & centimeter \\
\hline $\mathrm{cm} / \mathrm{s}$ & centimeters per second \\
\hline DOE & U.S. Department of Energy \\
\hline $\begin{array}{l}\text { EPA } \\
\mathrm{ft}\end{array}$ & $\begin{array}{l}\text { U.S. Environmental Protection Agency } \\
\text { foot }\end{array}$ \\
\hline GJPO & Grand Junction Projects Office \\
\hline ha & hectare \\
\hline in & inch \\
\hline km & kilometer \\
\hline LTSP & long-term surveillance plan \\
\hline m & meter \\
\hline MCL & maximum concentration limit \\
\hline mi & mile \\
\hline MSL & mean sea level \\
\hline NECA & Navajo Engineering and Construction Authority \\
\hline NRC & U.S. Nuclear Regulatory Commission \\
\hline NWS & National Weather Service \\
\hline $\mathrm{pCi} / \mathrm{m}^{2} \mathrm{~s}$ & picocuries per square meter per second \\
\hline QA & quality assurance \\
\hline RAP & remedial action plan \\
\hline RRM & residual radioactive material \\
\hline SM & survey monument \\
\hline sow & statement of work \\
\hline TAC & Technical Assistance Contractor \\
\hline UMTRA & Uranium Mill Tailings Remedial Action \\
\hline UMTRCA & Uranium Mill Tailings Radiation Control Act \\
\hline USBR & U.S. Bureau of Reclamation \\
\hline USGS & U.S. Geological Survey \\
\hline VCA & Vanadium Corporation of America \\
\hline
\end{tabular}




\subsection{INTRODUCTION}

The long-term surveillance plan (LTSP) for the Shiprock, New Mexico, Uranium Mill Tailings Remedial Action (UMTRA) Project disposal site describes the surveillance activities for the Shiprock disposal cell. The U.S. Department of Energy (DOE) will carry out these activities to ensure that the disposal cell continues to function as designed. This final LTSP was prepared as a requirement for acceptance under the U.S. Nuclear Regulatory Commission (NRC) general license for custody and long-term care of residual radioactive materials (RRM). This LTSP documents the land ownership interests and details how the long-term care of the disposal site will be carried out. It is based on the DOE's Guidance for Implementing the UMTRA Project Long-term Surveillance Program (DOE, 1992a).

\subsection{BACKGROUND}

Title I of the Uranium Mill Tailings Radiation Control Act (UMTRCA) of 1978 (42 USC $\$ 7901$ et seq.) authorized the DOE to perform remedial action at 24 inactive uranium mill tailings processing sites to reduce the potential effect on public health from the unstabilized RRM in and around the uranium mill tailings. The Shiprock, New Mexico, uranium mill tailings processing site in San Juan County was one of the 24 sites identified for remediation in the UMTRCA.

The Shiprock site and adjacent lands are part of the Navajo Indian reservation. The DOE and the Navajo Nation entered into a cooperative agreement under the UMTRCA, establishing the terms and conditions of the remedial action (DOE Cooperative Agreement No. DE-FC04-83AL16258, October 7, 1983). The DOE described and evaluated its plan for stabilizing the RRM at the Shiprock site in an environmental assessment (DOE, 1984) and a remedial action plan (RAP) (DOE, 1985). Concurrence from the NRC on the completion of the remedial action at Shiprock was received on May 9, 1991 (Attachment 1).

The remedial action was performed to meet the U.S. Environmental Protection Agency's (EPA) cleanup standards for inactive uranium processing sites (40 CFR Part 192, Subparts A-C). The NRC concluded that the DOE adequately characterized the hydrogeology and ground water conditions of the Shiprock disposal site to demonstrate compliance with the ground water protection aspects of the original EPA standards (issued on January 5, 1983). The NRC determined that the EPA's proposed ground water protection standards (proposed rule published in 52 FR 36000 on September 24, 1987) do not apply to the Shiprock disposal site because the NRC had already concurred with the remedial action at the Shiprock site in 1985 before the proposed standards were issued. The NRC concurred with the DOE's plan to address compliance with the proposed EPA ground water standards in the floodplain alluvium and on the terrace beyond the disposal cell as part of the DOE's ground water restoration program for the UMTRA Project (NRC, 1990; 1991). 


\subsection{LICENSING PROCESS}

The NRC has developed regulations (10 CFR \$40.27) [effective November 29, 1990 (55 FR 45591)] issuing a general license for the long-term care of DOE UMTRA Project (Title I) disposal sites, including the Shiprock disposal site. The license is available only to the DOE (or any successor federal agency designated by the President) and has no termination date. The purpose of this general license is to ensure that the UMTRA Project disposal sites will be cared for in a manner that protects the public health and safety and the environment after the NRC concurs that the remedial action is complete (i.e., acceptance of the sitespecific completion report and certification summary) at that site and formally accepts the site-specific LTSP that meets the requirements of 10 CFR $\$ 40.27$. The site-specific completion report documents the site as-built conditions. The DOE prepares a certification summary memorandum certifying satisfaction of approved RAP provisions and compliance with EPA standards. The DOE compiles the final completion report, final audit report, and certification summary into the certification report and submits it to the NRC for concurrence (DOE, 1993a).

When the general license becomes effective, following approval of the LTSP, responsibility for the long-term surveillance program will be transferred to the DOE Grand Junction Projects Office (GJPO), Grand Junction, Colorado. The programmatic transfer will occur within 30 days of NRC notification that the license is in effect.

\section{Acquisition}

No requirement exists in 10 CFR Part 40 to provide a custodial care agreement. However, the DOE will provide evidence of permanent access to the disposal site for long-term care activities. Negotiations are currently underway between the DOE and the Navajo Tribe that will lead to an acceptable access agreement. The access agreement of the Shiprock disposal site will be provided in Attachment 2.

A legal description of the Shiprock disposal site and documentation of site custody will be provided in Attachment 2.

\subsection{LONG-TERM SURVEILLANCE PLAN}

This LTSP meets the requirements of 10 CFR $\$ 40.27$ by addressing the following:

- Site description and ownership.

- Description of final site conditions.

- Site inspection procedures and personnel.

- Custodial maintenance and corrective action programs.

- Record keeping and reporting requirements.

- Quality assurance (OA).

- Emergency response. 


\subsection{FINAL SITE CONDITIONS}

\section{$2.1 \quad$ SITE HISTORY}

The former Navajo Mill at Shiprock was designed and built by Kerr-McGee Oil Industries, Inc. The mill, ore storage, raffinate ponds, and tailings piles occupied approximately 145 acres (ac) [58 hectares (ha)] leased from the Navajo Nation. Kerr-McGee operated the mill from 1954 until 1963, when it was purchased by the Vanadium Corporation of America (VCA). The VCA, which later merged with Foote Mineral Company, continued operations until 1968. When the lease expired in 1973, control of the site reverted to the Navajo Nation.

The mill processed a total of about 1.5 million short tons (1.4 million tonnes) of ore along with smaller quantities of bulk precipitates from heap leach operations (from the Monument Valley area) and purchased vanadium liquor. A two-stage sulfuric acid leaching circuit, countercurrent washing circuit, and uranium and vanadium solvent extraction circuits were used. Tailings from the washing circuit and yellow cake filtrates were pumped to the tailings disposal areas, while raffinate from the solvent extraction circuits was allowed to evaporate and infiltrate the ground from separate holding ponds.

After the site reverted to the Navajo Nation, a 40-ac (16-ha) portion of the 145-ac (58-ha) area was occupied by the Navajo Engineering and Construction Authority (NECA). The NECA established a training school for heavy equipment operators and used the lower tailings pile as a practice ground. These activities enlarged the pile and spread the tailings over most of the former holding pond area. In April 1974, the EPA conducted a radiation survey at the site. It noted that the training activities were adversely affecting radiological conditions and recommended that these activities be redirected toward decontamination of the site and interim stabilization of the tailings. This recommendation was accepted and carried out until mid-1978 with guidance and support from the EPA. The EPA guideline for off-pile decontamination was to reduce the net aboveground exposure rate to less than 10 microroentgens per hour above background (DOE, 1985).

The remedial action at the Shiprock disposal site was completed in 1986. Approximately 2.5 million tons (2.3 million tonnes) of contaminated materials . were stabilized in place in a disposal cell covering approximately 77 ac ( $31 \mathrm{ha}$ ). Tailings and contaminated materials from adjacent off-site areas (including the escarpment and the floodplain of the San Juan River and vicinity properties) were placed in the original tailings pile and compacted for stability, resulting in the existing disposal cell. The disposal cell and immediate surrounding area encompass approximately 105 ac (42 ha). 


\subsubsection{Description and location of disposal site area}

The Shiprock disposal site is in San Juan County, New Mexico, Sections 25 and 36, Township 30 North, Range 18 West, and in Section 31, Township 30 North, Range 17 West, New Mexico Principal Meridian (Figures 2.1 and 2.2). The site is located on a 105-ac (42-ha) tract of land on the Navajo Indian Reservation 1 mile (mi) [1.6 kilometers $(\mathrm{km})$ ] south of the town of Shiprock, New Mexico, on the southern bank of the San Juan River (DOE, 1992b). The town of Shiprock is approximately $30 \mathrm{mi}(48 \mathrm{~km})$ west of Farmington, New Mexico, and $27 \mathrm{mi}(40 \mathrm{~km})$ southeast of Four Corners. Figure 2.1 shows the main highways in the vicinity of the site. Additionally, the Shiprock disposal site can be reached using the following directions (Figure 2.2):

- From Shiprock, proceed south on U.S. Highway 666.

- From the junction of U.S. Highway 64 and U.S. Highway 666 south of Shiprock, proceed south on U.S. Highway 666 for $0.3 \mathrm{mi}(0.5 \mathrm{~km})$ to a gravel road.

- Proceed east on the gravel road for $0.5 \mathrm{mi}(0.8 \mathrm{~km})$ to the NECA compound.

The Shiprock disposal site is on an elevated river terrace on the southwest side of the San Juan River (Figure 2.3). The area is relatively level, with natural elevation ranging from approximately 4980 feet $(\mathrm{ft})$ (1520 meters [m]) above mean sea level (MSL) along the southwestern edge of the property to a low of about $4940 \mathrm{ft}(1510 \mathrm{~m})$ along the top of a $50-\mathrm{ft}(15-\mathrm{m})$ high, northwestsoutheast trending escarpment that separates the elevated terrace from the modern floodplain of the San Juan River. Southwest of the disposal site, the terrace continues gently upward for approximately $0.5 \mathrm{mi}(0.8 \mathrm{~km})$, where it meets the weathered and colluvial covered bedrock uplands at an elevation of about $5040 \mathrm{ft}(1540 \mathrm{~m})$ above MSL.

The floodplain of the San Juan River is at the base of the escarpment to the north of the disposal cell. It begins approximately $1500 \mathrm{ft}(460 \mathrm{~m})$ upstream of the site, widens to about $1600 \mathrm{ft}(490 \mathrm{~m})$, then pinches out against the bedrock escarpment at the bridge supporting U.S. Highway 666 over the San Juan River, approximately $2000 \mathrm{ft}(610 \mathrm{~m})$ downstream of the northwestern corner of the site.

Two arroyos are located to the east and west of the tailings site. Bob Lee Wash is an arroyo bordering the western side of the site. Many Devils Wash is a parallel arroyo approximately $0.5 \mathrm{mi}(0.8 \mathrm{~km})$ southeast of the site.

The climate of the region is generally arid and desert-like. On the terrace above the San Juan River, vegetation is sparse. Some of the floodplain was cleared of 

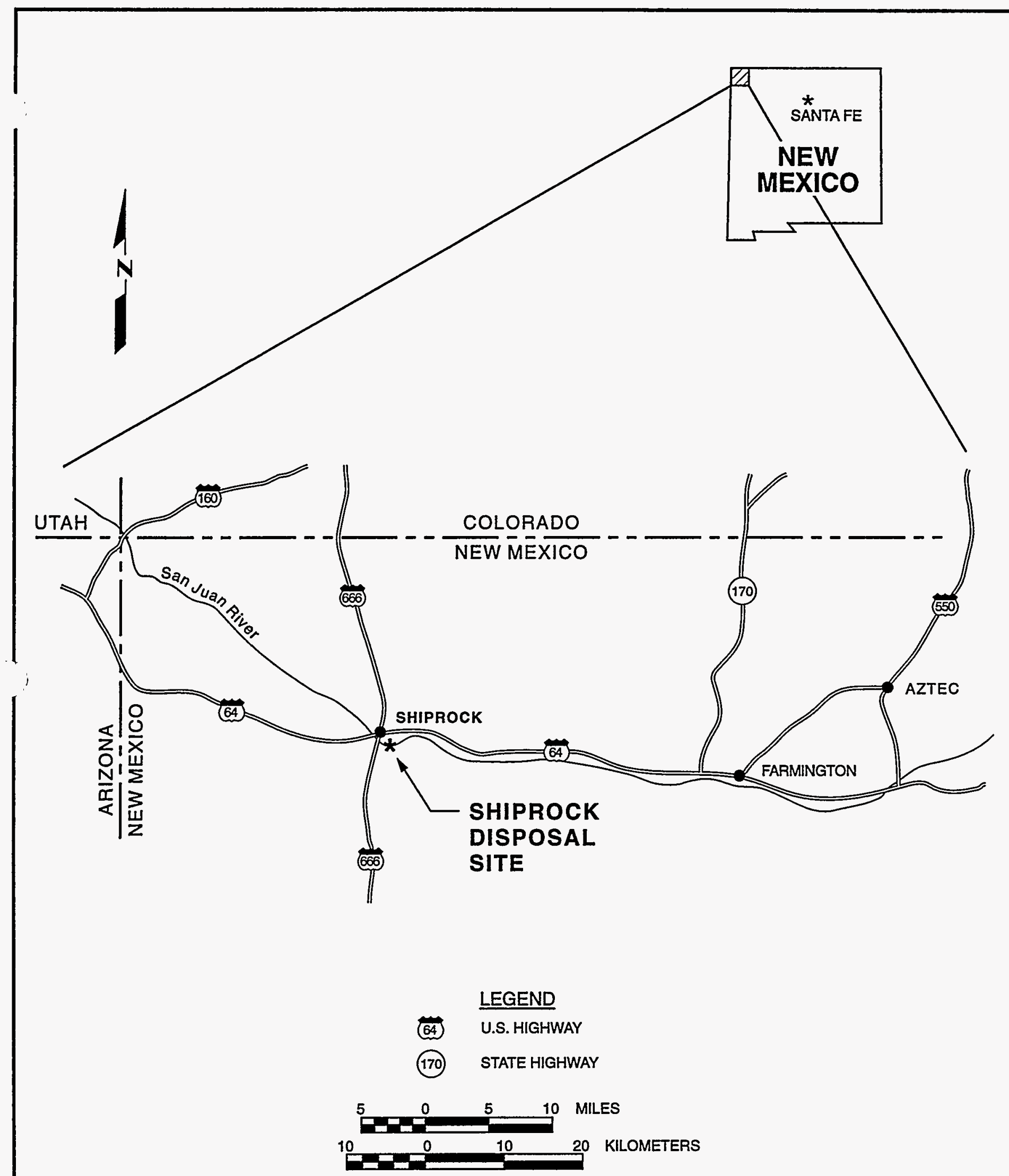

FIGURE 2.1

AREA MAP

SHIPROCK, NEW MEXICO, DISPOSAL SITE 


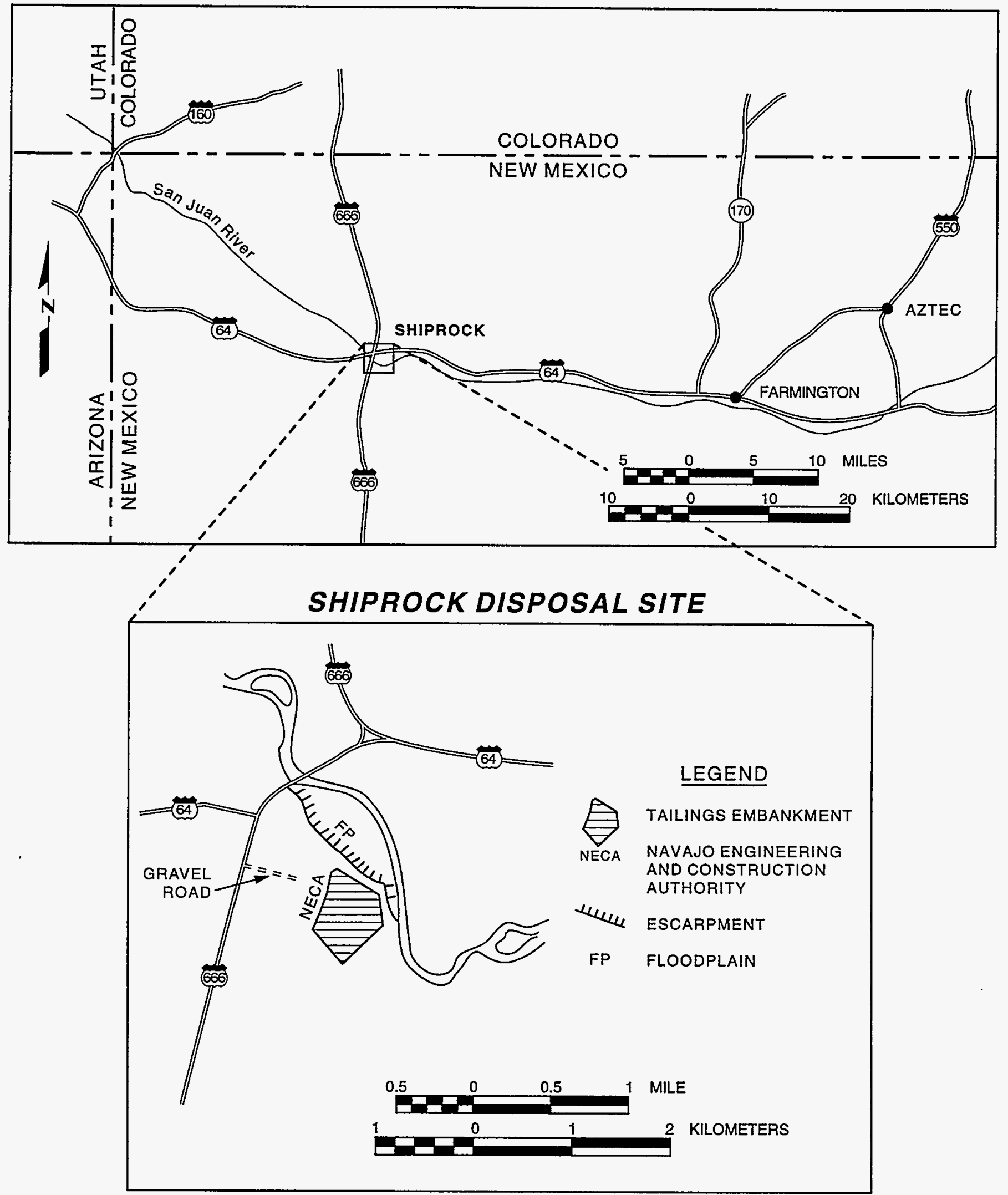

FIGURE 2.2

DISPOSAL SITE LOCATION

REF: DOE, 1992b.

SHIPROCK, NEW MEXICO 


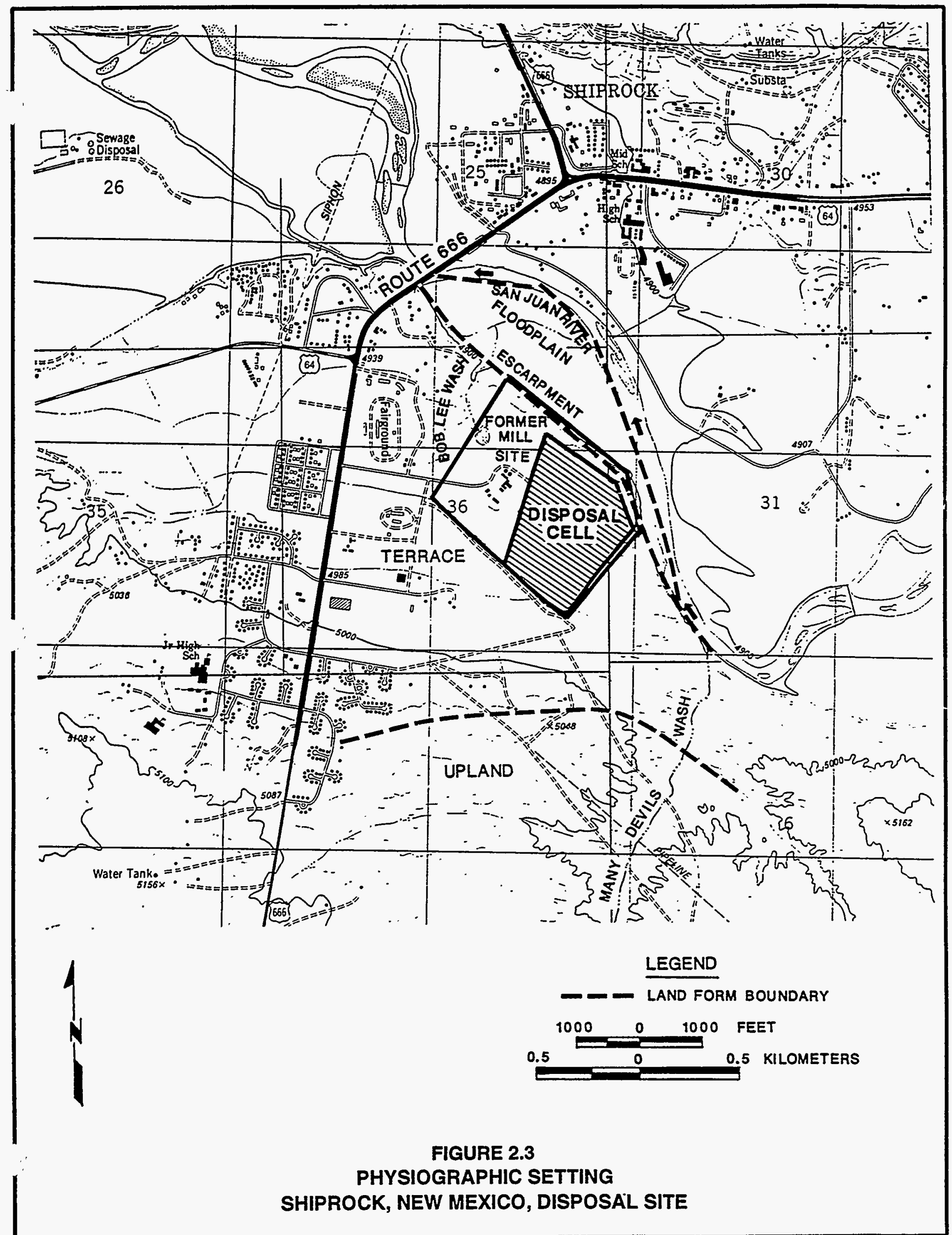


vegetation during remediation, but in other areas vegetation, consisting mainly of tamarisks, is extremely dense.

\subsubsection{Neighboring land uses}

The Shiprock disposal site is on the Navajo Indian reservation adjacent to the unincorporated town of Shiprock. Figure 2.4 shows the land uses in the vicinity of the site.

According to unofficial estimates of Shiprock's population in 1980 (FBDU, 1981), there were 90 people living within $0.5 \mathrm{mi}(0.8 \mathrm{~km})$ of the site and 2200 within $1 \mathrm{mi}(1.6 \mathrm{~km})$. In 1983, the population of Shiprock was estimated at 8000 .

A mix of residential and commercial development exists near the site. A U.S. Public Health Service building, NECA facilities, Abandoned Mine Land Program office buildings, and fairgrounds are immediately west of the former mill site. West of U.S. Highway 666 is a residential area. The regraded borrow pit used to supply cover material for the disposal cell is south of the site.

Several residences are located west of Bob Lee Wash and southwest of the site. Approximately 80 people live in a residential area west of Bob Lee Wash (TAC, 1993). This community consists of approximately 15 households. A field search and inquiries in 1993 did not identify any domestic or other wells north of the San Juan River within or near the residential areas neighboring the site. Treated San Juan River water is provided to these residents by the Navajo Tribal Utility Authority (DOE, 1993b). NECA is also connected to the municipal water and sewer systems.

\subsubsection{Disposal site access and security}

Two locked gates provide restricted access to the Shiprock disposal site (Plate 1): one to the disposal cell and the other to the terrace north and east of the disposal cell.

The locked gate at the far west corner of the security fence around the disposal site allows entry to the disposal cell. Access to the terrace north and east of the disposal cell is through the locked gate at the north end of the NECA compound. This gate is at the far west corner of the security fence around the northwest-directed outflow channel area. There are 23 perimeter signs and 2 entrance signs providing notice to the public concerning the purpose of the site. Two site markers identifying the contents of the disposal cell are also located at the site.

Navajo authorities will be notified periodically of DOE site visits so that they may choose to send observers. Keys to the locks on the disposal site gates are held by the Navajo Nation. Additional keys are kept by the DOE UMTRA Project 


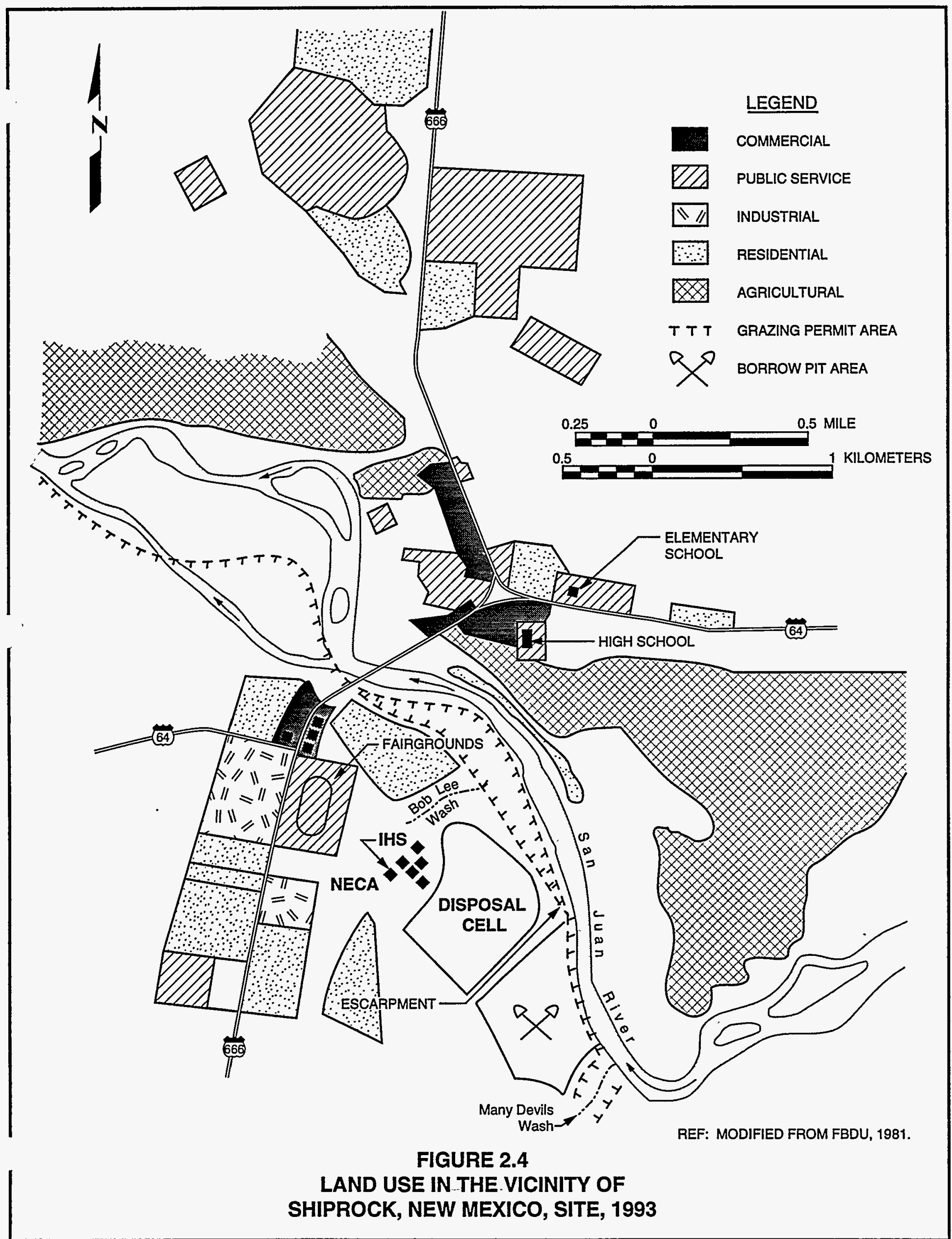


Manager; the Technical Assistance Contractor (TAC) UMTRA Project Manager; and the GJPO Supervisory, General Engineer (Table 2.1).

Table 2.1 Shiprock disposal site access key holders

\begin{tabular}{|c|c|c|}
\hline Title and current contact & Telephone & Address \\
\hline DOE UMTRA Project Manager & $(505) 845-4022$ & $\begin{array}{l}\text { U.S. Department of Energy } \\
\text { UMTRA Project Office } \\
2155 \text { Louisiana NE, Suite } 4000 \\
\text { Albuquerque, New Mexico } 87110\end{array}$ \\
\hline TAC UMTRA Project Manager & (505) 888-1300 & $\begin{array}{l}\text { Jacobs Engineering Group Inc. } \\
2155 \text { Louisiana NE, Suite } 10,000 \\
\text { Albuquerque, New Mexico } 87110\end{array}$ \\
\hline $\begin{array}{l}\text { Supervisory, General Engineer } \\
\text { GJPO }\end{array}$ & (303) 248-6006 & $\begin{array}{l}2597 \text { B } 3 / 4 \text { Road } \\
\text { Grand Junction, Colorado } 81503\end{array}$ \\
\hline
\end{tabular}

The scheduled Shiprock disposal site inspections (Section 6.0) will monitor the effectiveness of the security measures at the Shiprock disposal site. The DOE 24-hour emergency telephone number on the entrance signs (Section 4.0) and agreements with local agencies to notify the DOE in the event of an emergency or breach of site integrity (Section 11.0) will provide additional security measures.

\subsubsection{Disposal cell design}

The final condition of the Shiprock disposal cell is shown in Plate 1. The abovegrade disposal cell is an asymmetrical pentagon with a maximum side length of $1800 \mathrm{ft}(550 \mathrm{~m})$ and a minimum side length of $800 \mathrm{ft}(244 \mathrm{~m})$. The maximum height of the disposal cell is approximately $48 \mathrm{ft}(15 \mathrm{~m})$ above the original ground surface. The sides of the disposal cell have a maximum slope of one vertical to five horizontal. The top varies in slope from 2 to 4 percent. The disposal cell covers approximately 77 ac (31 ha).

Figure 2.5 shows a typical cross section of the Shiprock disposal cell cover. The cover consists of two components: an infiltration/radon barrier and an erosion protection layer. The infiltration/radon barrier is $6.4 \mathrm{ft}(2 \mathrm{~m})$ thick on the top and $7.0 \mathrm{ft}(2.1 \mathrm{~m})$ thick on the sides. This layer consists of predominantly sandy silt compacted to a hydraulic conductivity of not more than $2.5 \times 10^{-5}$ centimeters per second $(\mathrm{cm} / \mathrm{s})$. It was designed to protect the ground water by minimizing infiltration into the disposal cell and reduce radon emanations from the disposal cell to less than 20 picocuries per square meter per second (pCi/m²s). 


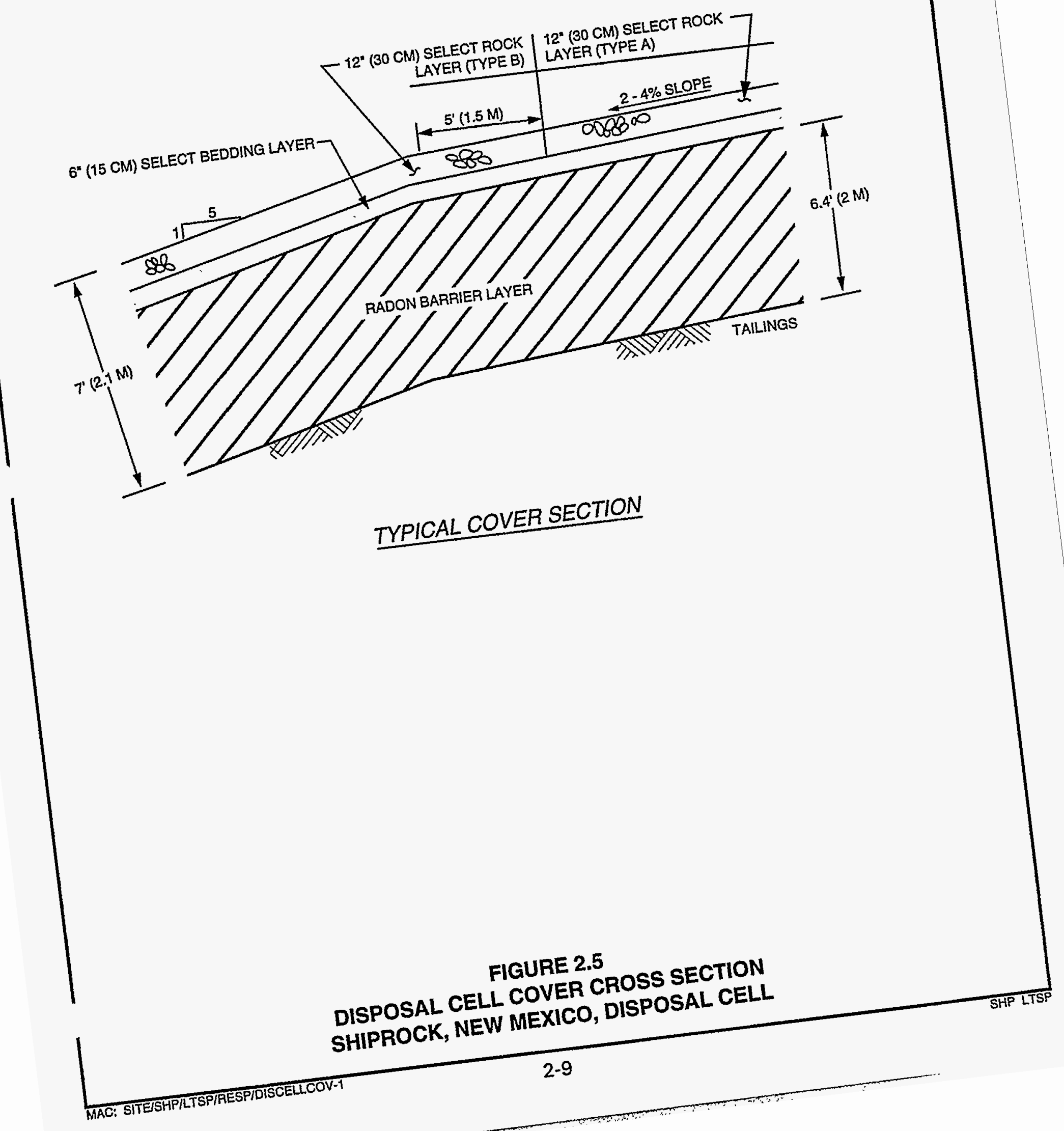


The erosion protection layer on the top consists of a $1-\mathrm{ft}(0.3-\mathrm{m})$ thick layer of Type A riprap underlain by a 6 -inch (in) [15-centimeter $(\mathrm{cm})]$ thick layer of bedding material. For the sides, this layer consists of a $1-\mathrm{ft}(0.3-\mathrm{m})$ thick layer of Type B riprap underlain by a 6 -in $(15-\mathrm{cm})$ thick layer of bedding material. The as-built rock cover is twice the required thickness as indicated by site calculations for erosion control.

A rock-lined drainage ditch diverts surface water runoff around and away from the disposal cell to a rock-lined dissipation area.

\subsubsection{Design features to be monitored}

The surface conditions of the disposal cell will be monitored during the scheduled inspections to determine whether the disposal cell and erosion protection measures are performing as designed. Guidelines to be followed when inspecting the disposal cell and criteria for corrective actions or repairs are as follows:

- Crest-Observations will be made in all directions for any features that are anomalous or unexpected and may require a closer inspection. Inspectors will walk around the edge and along diagonal transects of the crest at approximately 50-yd (46-m) intervals. The inspectors will search for evidence of any differential settling, subsidence, or cracks. The rock cover will be examined for evidence of rapid deterioration. Individual rocks will be examined for excessive fracturing, oxidation, or other signs of deterioration. Areas of sand accumulation and volunteer plant growth will be noted.

- Slopes-Modifications to the disposal site are most likely to occur on the lower portions of the slopes. Therefore, a careful examination at the toe of the slope will be a key part of this inspection. Settlement or sliding, although highly unlikely, will be apparent by the presence of bulges and depressions, cracks, or scarps. Any localized change in vegetation will be described and examined. During the inspections, the slopes will be examined for evidence of animal intrusion, burrowing, changes in vegetation, and human activity. Cattle, sheep, or wildlife may inadvertently wander onto the site, but they are not likely to remain.

- Drainage ditch and diversion channels-The inspectors will walk along the entire length of each channel to determine whether the channels have been functioning and can be expected to continue to function as designed. The channels and sideslopes will be examined for evidence of erosion or sedimentation, slides, incipient erosion channels, debris, or growing vegetation. The sideslopes will also be examined for evidence of piping or burrowing by animals, which could lead to sloughing of material into the channel. 


\subsection{SITE DRAWINGS AND PHOTOGRAPHS}

At the completion of remedial action, the Shiprock disposal site as-built conditions were documented with as-built drawings, baseline photographs, and aerial photographs (MK-F, 1987a). This information illustrates baseline conditions against which future conditions at the disposal site can be compared.

A site atlas was prepared that includes a vicinity map, a topographic map, and a disposal site map. The site atlas will become part of the Shiprock permanent site file. The site atlas will be updated, as necessary, after each site inspection. All drawings, maps, and photographs will be archived by the UMTRA Project Document Control Center. These maps, drawings, and photographs may be further modified by GJPO, as necessary, and GJPO will be responsible for maintaining and archiving these maps, drawings, and photographs after the Shiprock permanent site file is transferred to the GJPO. An index of the Shiprock permanent site file is provided in Attachment 3.

The Shiprock disposal vicinity site map encompasses an area with a radius of approximately $1.5 \mathrm{mi}(2.4 \mathrm{~km})$ from the center of the disposal site.

The Shiprock disposal site vicinity map documents the disposal site boundary; the disposal cell; the latitude and longitude, section, township, range, and principal meridian of the site; the surface drainage systems; and the roads.

\subsection{DISPOSAL SITE MAP}

A topographic survey was made of the Shiprock disposal site following completion of the remedial action. The map has a scale of 1 in $=200 \mathrm{ft}$ and a contour interval of $10 \mathrm{ft}$. In addition to topography, the map defines the following:

- Disposal site property boundary, fences, gates, and access roads.

- Outline of the base and crest of the disposal cell.

- Permanent site surveillance features (e.g., monuments, markers, and signs).

- Settlement plates.

- Site coordinate system.

The Shiprock disposal site map is presented in Plate 1.

The Shiprock disposal site map will serve as the base map for site inspections (Section 6.5). A new, separate inspection map will be prepared after each inspection. Each site inspection map will indicate the year of the inspection and the type of inspection. All Shiprock site base maps and periodic site inspection maps will become part of the Shiprock permanent site file. 
Upon completion of remedial action, as-built conditions were documented in final as-built drawings. The as-built drawings are included in the Shiprock completion report (MK-F, 1987a) and are in the Shiprock permanent site file. The as-built drawings may be used to document changes in physical site conditions or changes to the disposal cell over time for developing corrective action plans, if required.

At licensing, the RAC will transfer one original set of as-built drawings to the GJPO. These drawings will be filed in the site atlas, which is maintained in the Lakeview permanent site file (Attachment 3) at the GJPO.

\subsection{SITE BASELINE PHOTOGRAPHS}

A photographic record of final site conditions is located in the Shiprock permanent site file. This record consists of a series of aerial and ground photographs that provide a baseline visual record of final site construction activities and final site conditions to complement the as-built drawings.

In addition, the final completion report for the disposal site contains a complete set of photographs that document each phase of construction (MK-F, 1987a). The postconstruction photographs provide an orientation tool prior to site inspections and a baseline record of surveillance features.

\subsection{SITE AERIAL PHOTOGRAPHS}

Aerial photographs for the Shiprock disposal site were taken in 1987 after surface remedial action was completed. These aerial photographs provide a permanent record of final site conditions. The photographs will be used to monitor changes in site conditions (e.g., erosion patterns, vegetation changes, land use) over time and to provide a useful orientation tool prior to disposal site inspections. Aerial photographs are contained in the Shiprock permanent site file. The need for new aerial photographs will be evaluated at 5-year intervals, beginning with the year the license becomes effective for the Shiprock site. The specifications for aerial photographs at the Shiprock disposal site are summarized in Table 3.1. More detailed guidance is provided in Attachment 3 of the Guidance for Implementing the UMTRA Project Long-term Surveillance Program (DOE, 1992a).

\subsection{SITE INSPECTION PHOTOGRAPHS}

Photographs will be taken during site inspections to document conditions at the disposal cell and the disposal site. These photographs will provide a continuous record for monitoring changing conditions over time. The photographs can be compared with the baseline photographs to monitor site integrity. 
Table 3.1 Aerial photography specifications for the Shiprock disposal site

Area to be photographed

Products to be delivered

Flight date

Camera

Film

Filter

Flight line coverage

Ground control
Final disposal site plus a minimum of $0.25 \mathrm{mi}(0.40 \mathrm{~km})$ beyond site boundaries unless site conditions require otherwise.

One set of vertical color, infrared stereo contact prints, 9-in $(230 \mathrm{~mm})$, scale 1 in $=200 \mathrm{ft}(1 \mathrm{~mm}=240 \mathrm{~m})$ (representation fraction 1:2400); double weight, glossy, not trimmed.

One index map, scale 1 in $=200 \mathrm{ft}(1 \mathrm{~mm}=240 \mathrm{~m})$; flight lines and frame numbers will be provided.

One set of 2 each of low and high oblique photographs (and negatives) in natural color, 8- $\times 10$-in (200- $\times 250-\mathrm{mm})$; or 9- $\times$ 9-in (230- x 230-mm) contact prints.

To be determined upon the acceptance of this LTSP.

Precision, 9- $\times$ 9-in (230- $\times 230-\mathrm{mm})$ format for vertical photos. A 35-millimeter (single lens reflex) or larger format camera for oblique photos is acceptable.

Eastman-Kodak Aerochrome Infrared 2443, or its equivalent, for vertical photos.

Eastman-Kodak Ektacolor, or its equivalent, for oblique photos.

Wratten Nos. 12 or 15 for infrared photos. Skylight filter for color photos.

60 percent end overlap; 30 percent average side overlap.

Control stations will be second order, Class 1, for horizontal control and third order for vertical control (standard U.S. Geological Survey map accuracy specifications). 
Each photograph will be recorded individually on the photo log (Attachment 4). An appropriate description of the feature photographed, including the azimuth, if necessary, will be entered into the log. Copies of the disposal site inspection photographs and the photo log will be included in annual disposal site inspection reports.

If possible, a photograph will include a reference point such as a survey monument, boundary monument, site marker, or monitor well. For large-scale features such as drainage ditches or disposal cell slopes, a north arrow and scale will be included for reference.

For specific areas where a photograph is used to monitor change over time, the distance from the feature and the azimuth should be recorded, and all subsequent photographs should be taken from the same orientation to provide a more accurate picture of changing conditions. The magnetic declination of the compass should be corrected for true north. This information will also be provided on the site inspection checklist and photo log.

All site inspection photographs taken, as well as all corresponding photo log forms, will be maintained in the Shiprock permanent site file (Attachment 3 ).

\subsubsection{Features to be photographed}

The following site features should be documented through photographs during every scheduled inspection at the Shiprock disposal site:

- Monuments, signs, site markers, and erosion control markers.

- Fences, gates, and access roads.

- The disposal cell (crest, sideslopes, apron, and surrounding area). Panoramic sequences of photographs from selected vantage points may be used for this purpose.

- Sideslopes and changes along the grade between the topslopes and sideslopes.

- Diversion ditches.

- Off-site features that the inspector deems significant and that may affect the site in the future. These may include areas of the escarpment with significant sloughing, the main point of fluvial attack of the escarpment to the east of the site, and headward erosion from Bob Lee Wash at the northwestern corner of the site.

- Volunteer vegetation on the disposal cell and any other vegetation that may affect the integrity of the site. 
- Eolian sedimentation or erosion.

- Any other evidence of erosion the inspector deems significant (gullies, rills, etc.).

- Erosion protection material (riprap).

Any Shiprock disposal site feature or condition that requires the inspectors to make a written comment, explanation, or description will be photographed. These photographs will provide a record of developing trends in site conditions. These records will be used to make decisions concerning additional inspections, custodial maintenance or repairs, or corrective actions. The number of photographs, the view angles, and the lenses used will be up to the judgment of the inspectors, keeping in mind site conditions, lighting conditions, and the goal of having sufficient photographs for agency review. 


\subsection{PERMANENT SITE SURVEILLANCE FEATURES}

The permanent surveillance features at the Shiprock disposal site include survey and boundary monuments, erosion control markers, site markers, and entrance and perimeter signs. Eight boundary monuments and three survey monuments define the corners of the legal boundaries of the disposal site's fenced, irregularly shaped perimeter (Plate 1). Twenty-three signs were placed at spaced intervals around the perimeter of the disposal site so that one or more signs would be visible in daylight to a person approaching from any direction. Two signs were also posted at the two entrance gates to the site. One of the entrance signs and one granite site marker were placed at the entrance gate to the disposal cell located at the southwest corner. A second granite site marker was placed near the center of the crest of the disposal cell.

The construction and emplacement of the site surveillance features are described below and meet the specifications delineated in DOE's Guidance for Implementing the UMTRA Project Long-term Surveillance Program (DOE, 1992a).

\subsection{SURVEY MONUMENTS}

The three survey monuments (SM-1 through SM-3) at the disposal site consist of reinforced concrete monuments with Berntsen Model RT-1 metal markers cast into their tops (Figure 4.1). The magnet within the metal markers and the four metal bars used as reinforcement for the concrete will allow a metal detector to locate monuments should they become buried over time. The monuments extend approximately $1 \mathrm{ft}(0.3 \mathrm{~m})$ above the ground surface and $5 \mathrm{ft}(1.5 \mathrm{~m})$ below ground.

The three survey monuments are located on the north, west, and east corners of the site and establish a permanent horizontal control based on the project grid system (Table 4.1). Survey monument (SM)-1 is inside the security fence near the edge of the terrace north of the disposal cell (see Plate 1). SM-2 is inside the entrance gate near the southwest corner of the disposal cell. SM-3 is located outside the security fence near the east corner of the disposal cell. The U.S. Bureau of Reclamation (USBR) benchmark is N 10,000, E 10,000 located just northeast of SM-1. Coordinates for the survey and erosion control monuments are presented in Table 4.1. These monuments were surveyed to second-order survey standards in accordance with the DOE's LTSP guidance document (DOE, 1992a).

\subsection{BOUNDARY MONUMENTS}

Berntsen federal aluminum survey monuments, Model A-1, were used for the eight boundary monuments (Figure 4.2). Ceramic magnets are epoxied in the cap and base of each monument and are vertically oriented so that they can be detected easily if they become covered. Each 4-ft $(1.2-\mathrm{m})$ long monument is set with the cap approximately flush with the ground surface. 


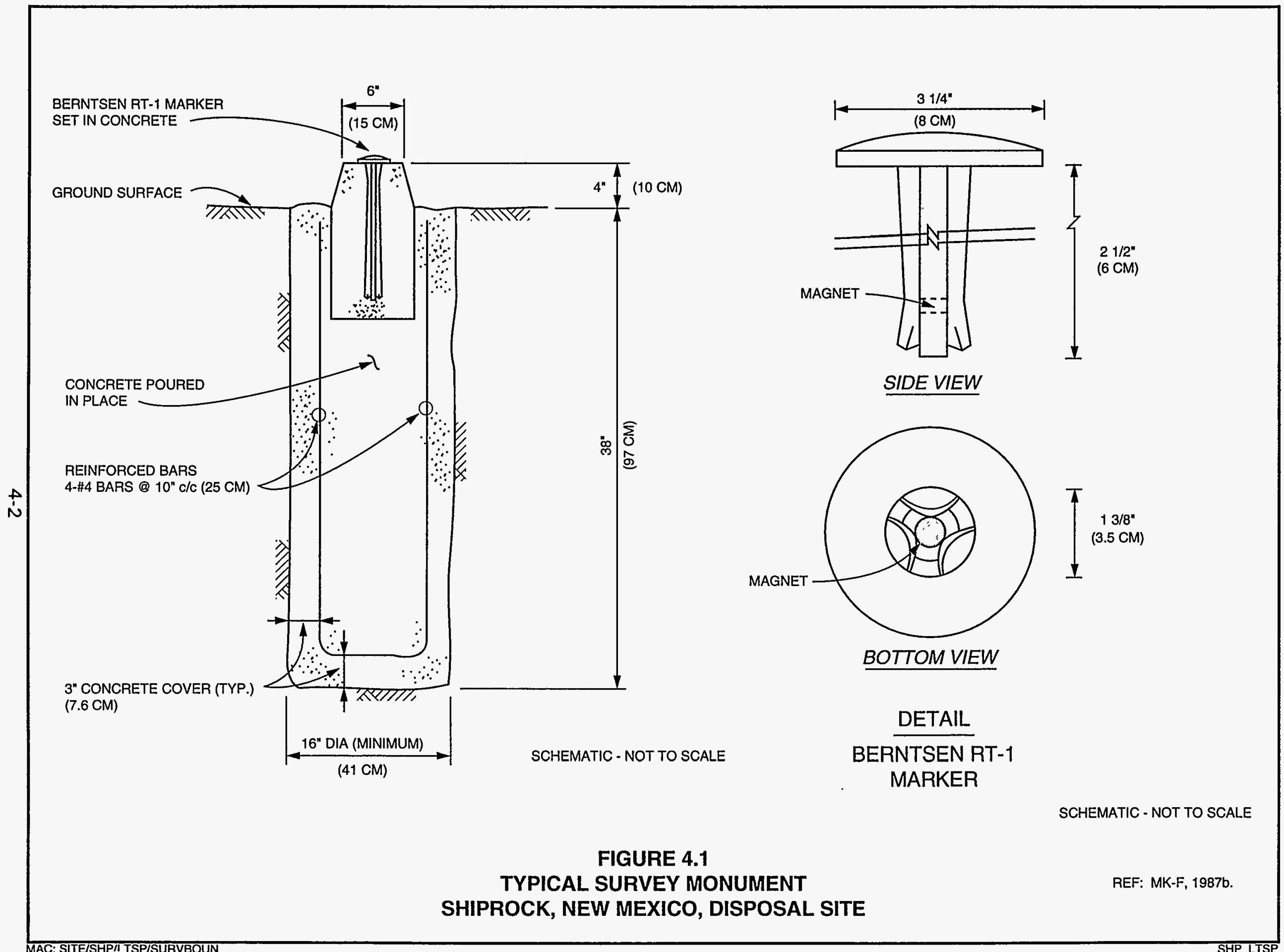


Table 4.1 Survey coordinates and elevations for survey monuments and erosion control markers at the Shiprock, New Mexico, disposal site

\begin{tabular}{lccc}
\hline & \multicolumn{2}{c}{ Coordinates $^{\mathrm{a}}$} & Elevation \\
\cline { 2 - 3 } Feature & North (N) & East (E) & (ft) \\
\hline Survey monument no. 1 & 9988.716 & 9996.083 & 4940.59 \\
Survey monument no. 2 & 7372.778 & 9660.897 & 4971.68 \\
Survey monument no. 3 & 7582.866 & $11,758.705$ & 4957.71 \\
Erosion marker no. 1 & 9287.530 & $10,725.032$ & 4956.33 \\
Erosion marker no. 1A & 9260.727 & $10,711.991$ & 4957.18 \\
Erosion marker no. 2 & 8770.181 & $11,396.851$ & 4959.36 \\
Erosion marker no. 2A & 8744.071 & $11,382.744$ & 4959.36 \\
Erosion marker no. 3 & 8467.083 & $11,771.022$ & 4960.59 \\
Erosion marker no. 3A & 8451.638 & $11,745.680$ & 4959.38 \\
Erosion marker no. 4 & 7030.900 & $12,217.951$ & 4958.95 \\
Erosion marker no. 4A & 7020.818 & $12,189.691$ & 4958.22 \\
\hline
\end{tabular}

asee Plate 1 for relative locations of these features. The coordinates are based on the project survey control point (N 10,000.00, E 10,000.00) located at the USBR benchmark just northeast of SM-1. 

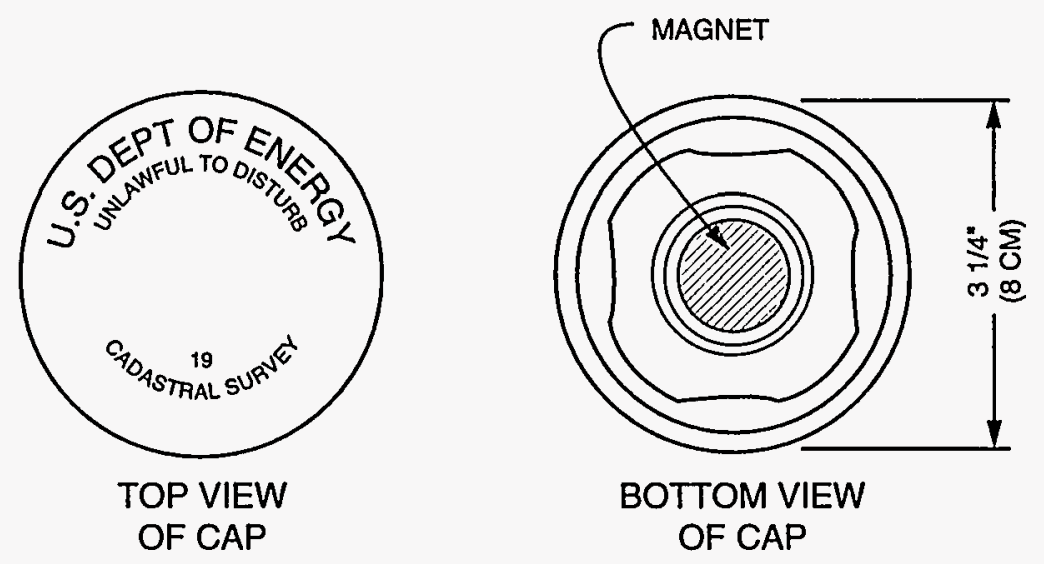

BOTTOM VIEW OF CAP

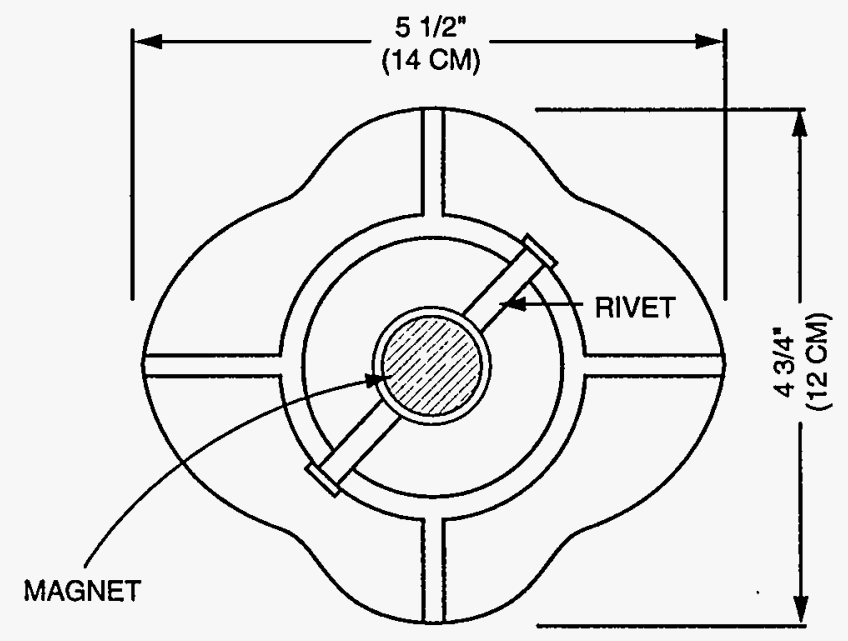

TOP VIEW OF BASE

SCHEMATIC - NOT TO SCALE

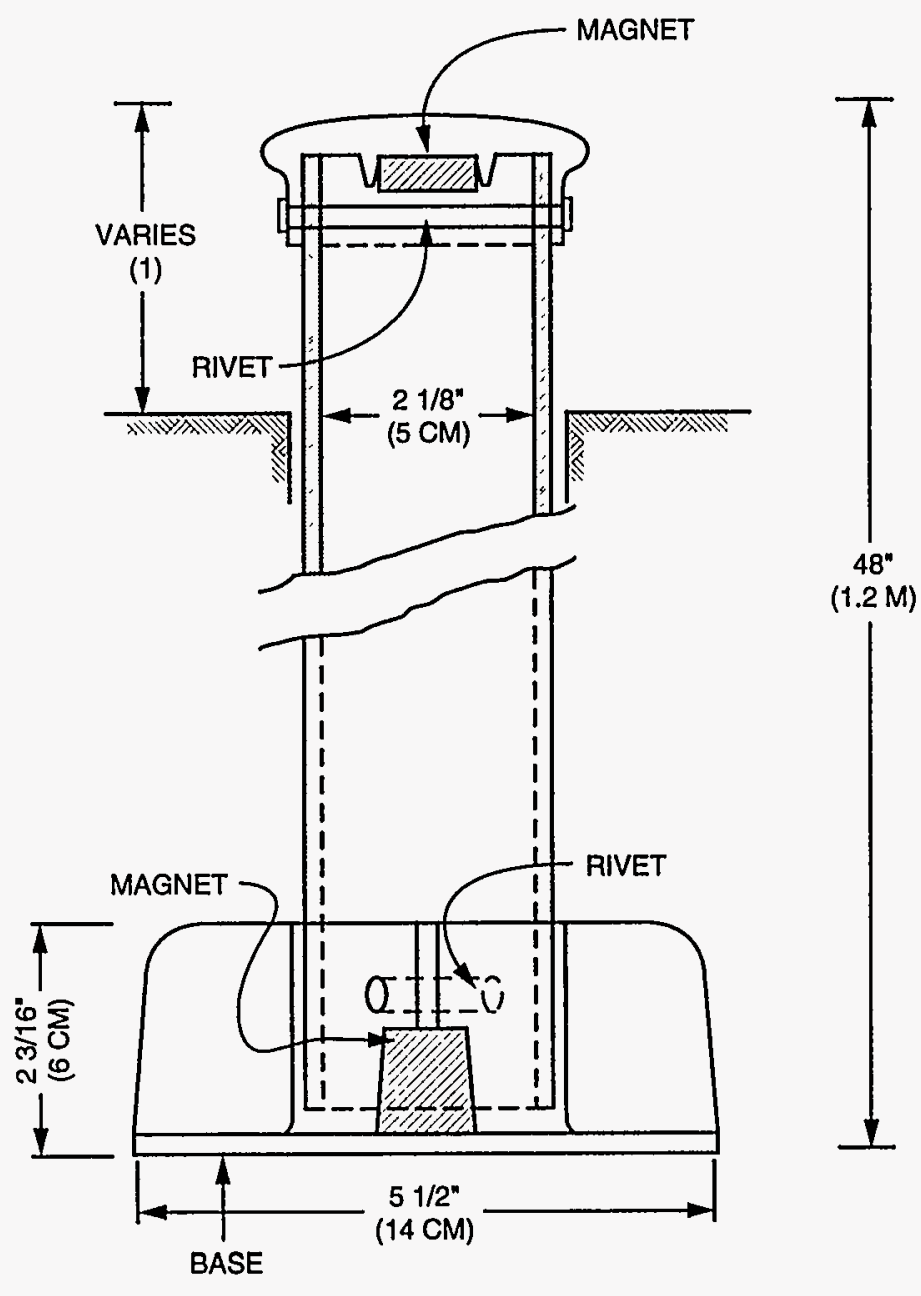

FIGURE 4.2

(1) BOUNDARY MONUMENTS ARE SET FLUSH WITH GROUND EROSION CONTROL MARKERS ARE SET I FT (0.3 M) ABOVE GROUND.

TYPICAL BOUNDARY MONUMENT/EROSION CONTROL MARKER SHIPROCK, NEW MEXICO, DISPOSAL SITE 


\subsection{SITE MARKERS}

Two unpolished granite site markers were installed on the Shiprock disposal cell. Site marker SMK-1, located near the entrance to the disposal cell, is set in a bed of reinforced concrete that extends $4.3 \mathrm{ft}(1.3 \mathrm{~m})$ below ground surface (Figure 4.3). Site marker SMK-2, located at the crest of the disposal cell, is set in a bed of reinforced concrete that extends to the bottom of the riprap layer (Figure 4.4). The inscriptions on the two site markers identify the general location of the Shiprock disposal cell, the boundary of the site, the date of closure (September 1986), the tonnage of tailings $(2,520,000$ tons), and the curies of radioactivity (746 curies of Ra-226). The international radiation symbol is also inscribed in each marker (Figure 4.5).

\subsection{ENTRANCE AND PERIMETER SIGNS}

Signs are posted on the two entrance gates to the Shiprock disposal site. The entrance signs are of the dimensions and specifications shown in Figure 4.6. The 23 perimeter signs mounted on the fence around the disposal site display the international symbol indicating the presence of radioactive materials and state that the site contains uranium mill tailings and that trespassing is forbidden. The perimeter signs are of the dimensions and specifications shown in Figure 4.6. The locations of perimeter signs are shown in Plate 1.

\subsection{SETTLEMENT PLATES}

The Shiprock disposal cell contains 12 settlement plates (Figure 4.7). These plates were installed during construction across the northeastern portion of the cell where fill was placed over substantial thicknesses of slime tailings (Plate 1). These settlement plates were monitored during and immediately following construction to determine whether any differential settlement was occurring. The monitoring data indicated that settlement was essentially complete before final grading was performed.

The settlement plates were not intended to be used as permanent surveillance features, and there are no plans to monitor them routinely. However, if future site inspections detect settling problems in the northeastern portion of the disposal cell, these plates could be surveyed. Table 4.2 shows the elevations of the settlement plates at the completion of remedial action. These elevations are considered the baseline against which any future measurements would be compared.

\subsection{ADDITIONAL SITE SURVEILLANCE FEATURES}

\subsubsection{Erosion control markers}

Four pairs of erosion control markers (eight total) were installed along the edge of the escarpment at the locations shown in Plate 1. The erosion control markers are Berntsen Model A-1 boundary monuments (Figure 4.2) with the 


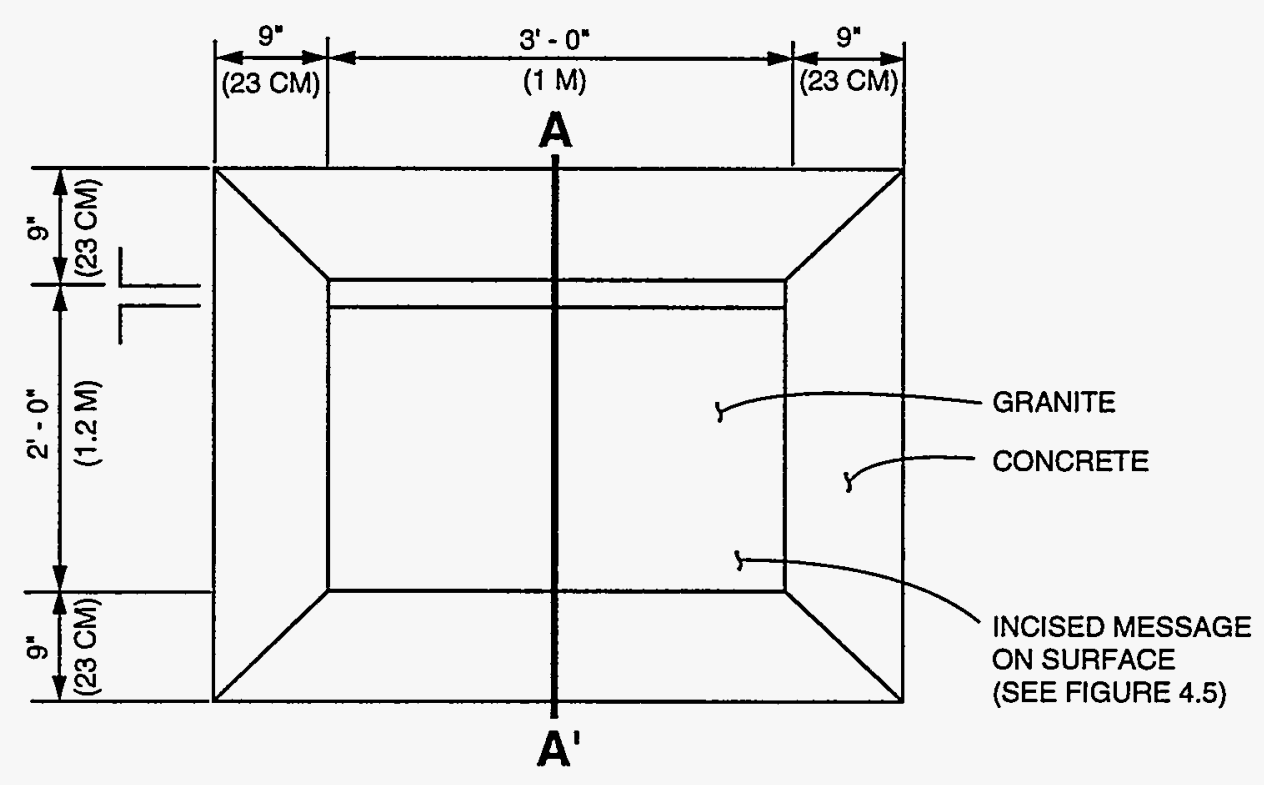

PLAN VIEW

SCHEMATIC - NOT TO SCALE

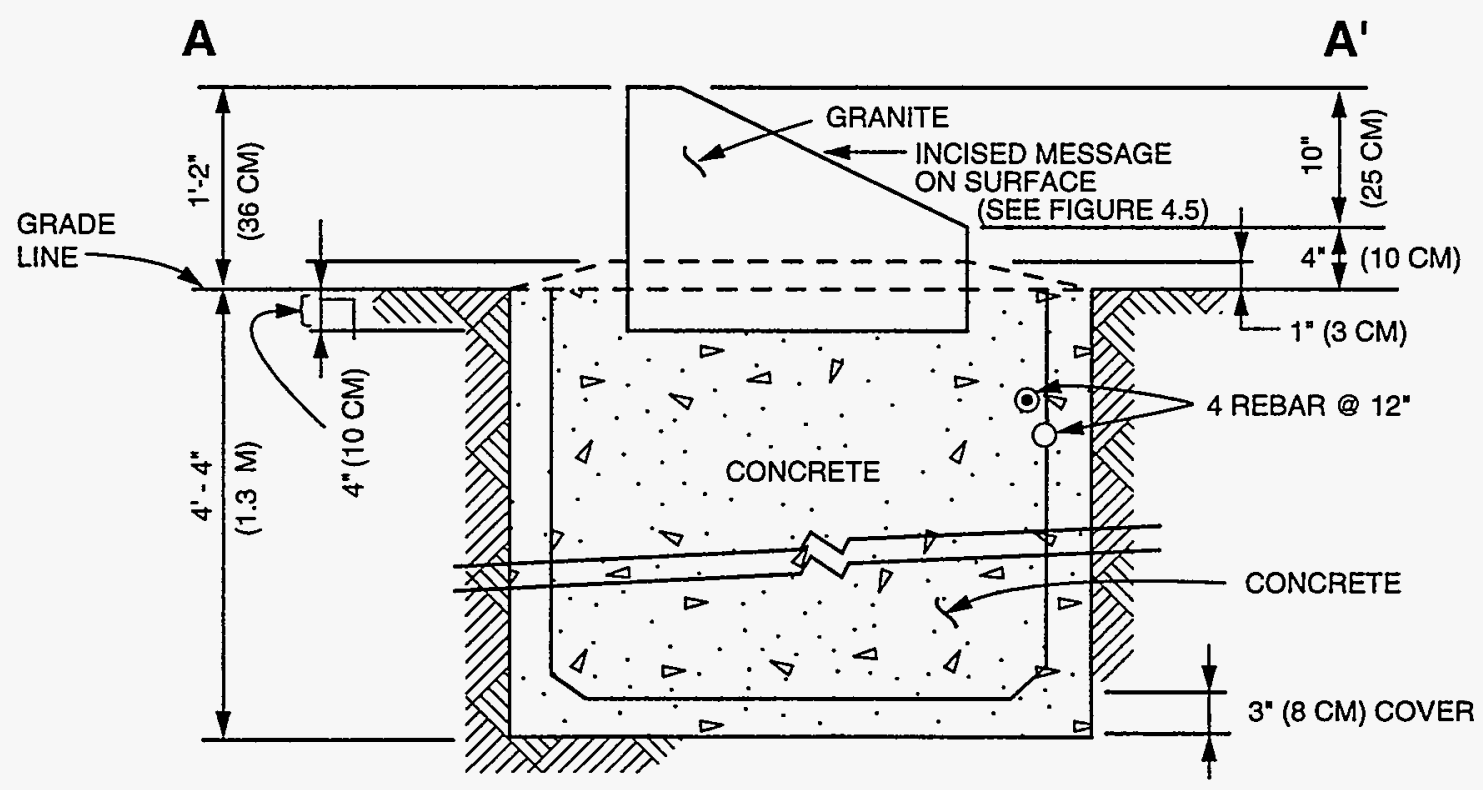

SECTION A-A'

SCHEMATIC - NOT TO SCALE

REF: MK-F, $1987 b$.

FIGURE 4.3

SITE MARKER - SMK-1

LOCATED AT SITE ENTRANCE

SHIPROCK, NEW MEXICO, DISPOSAL SITE 


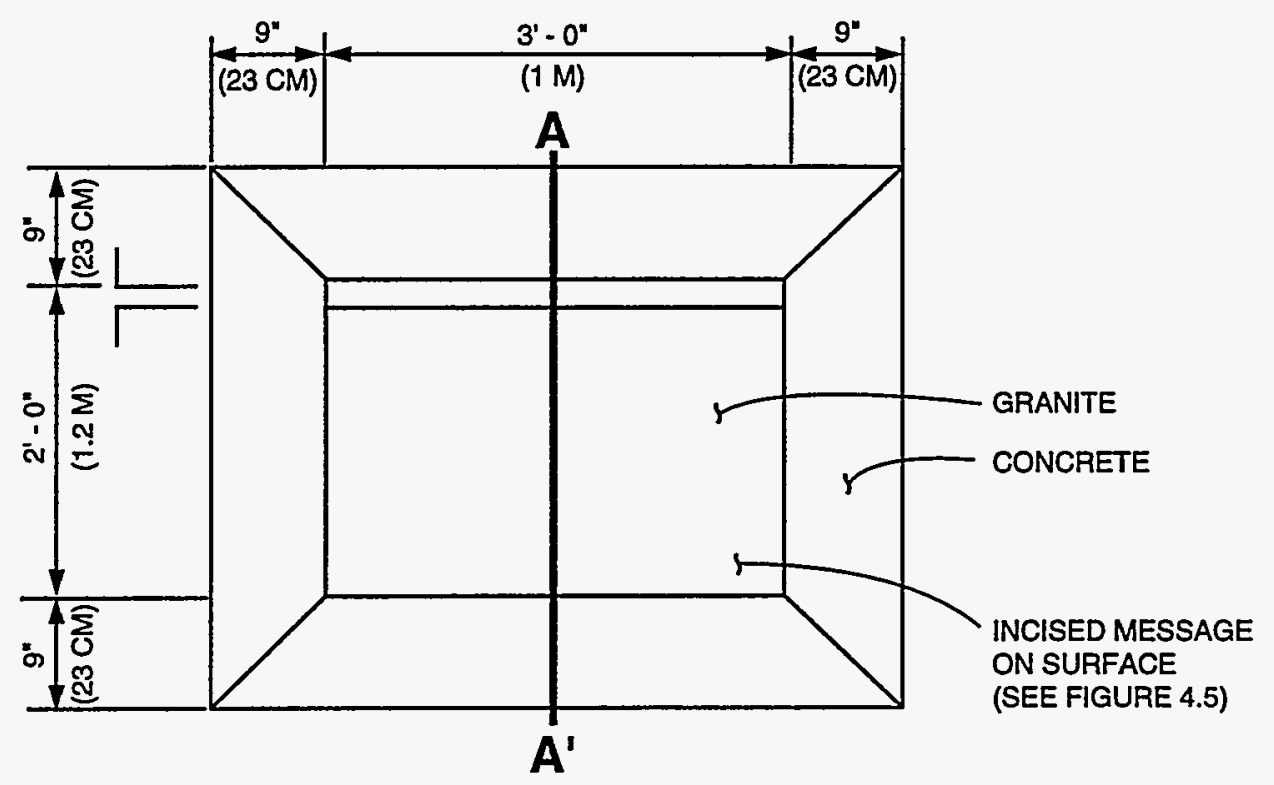

PLAN VIEW

SCHEMATIC - NOT TO SCALE

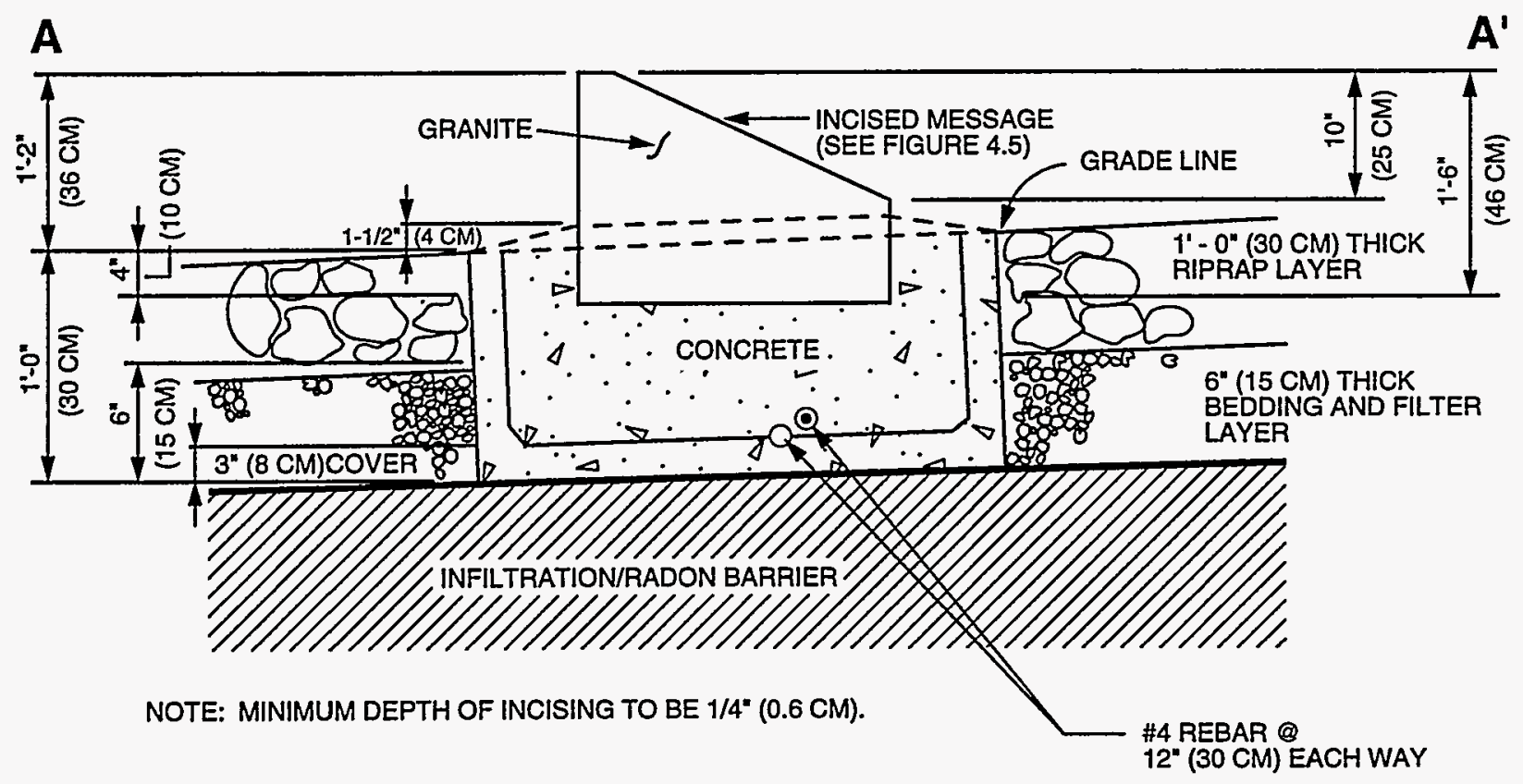

SECTION A - $A^{\prime}$

SCHEMATIC - NOT TO SCALE

FIGURE 4.4

SITE MARKER - SMK-2

LOCATED AT CREST OF DISPOSAL CELL SHIPROCK, NEW MEXICO, DISPOSAL SITE 


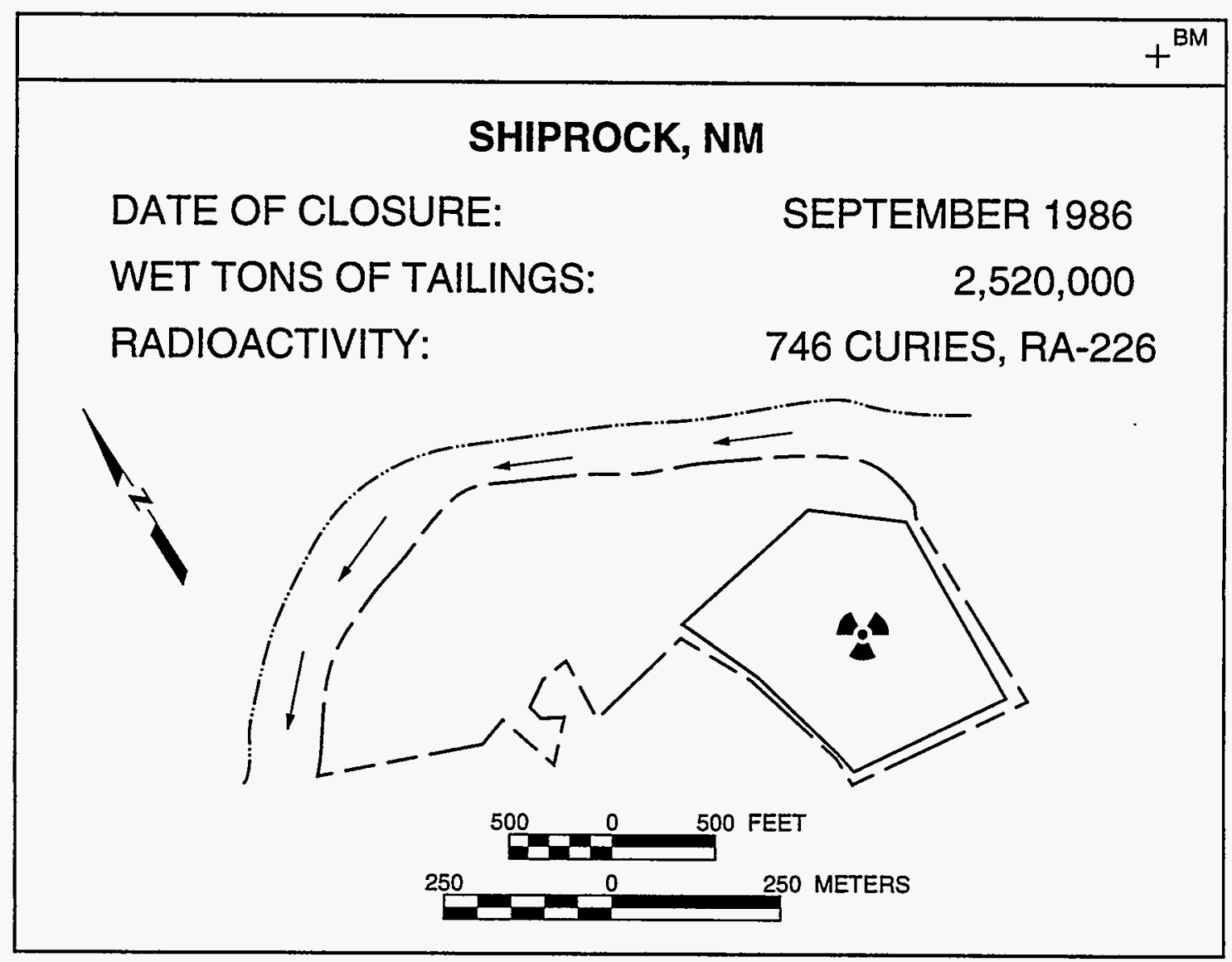

NOTE: MINIMUM DEPTH OF INCISING IS $1 / 4^{\prime \prime}$ (6CM).

INCISED MESSAGE

REF: MK-F, 1987b.

FIGURE 4.5

SITE MARKER INCISED MESSAGE

SHIPROCK, NEW MEXICO, DISPOSAL SITE 


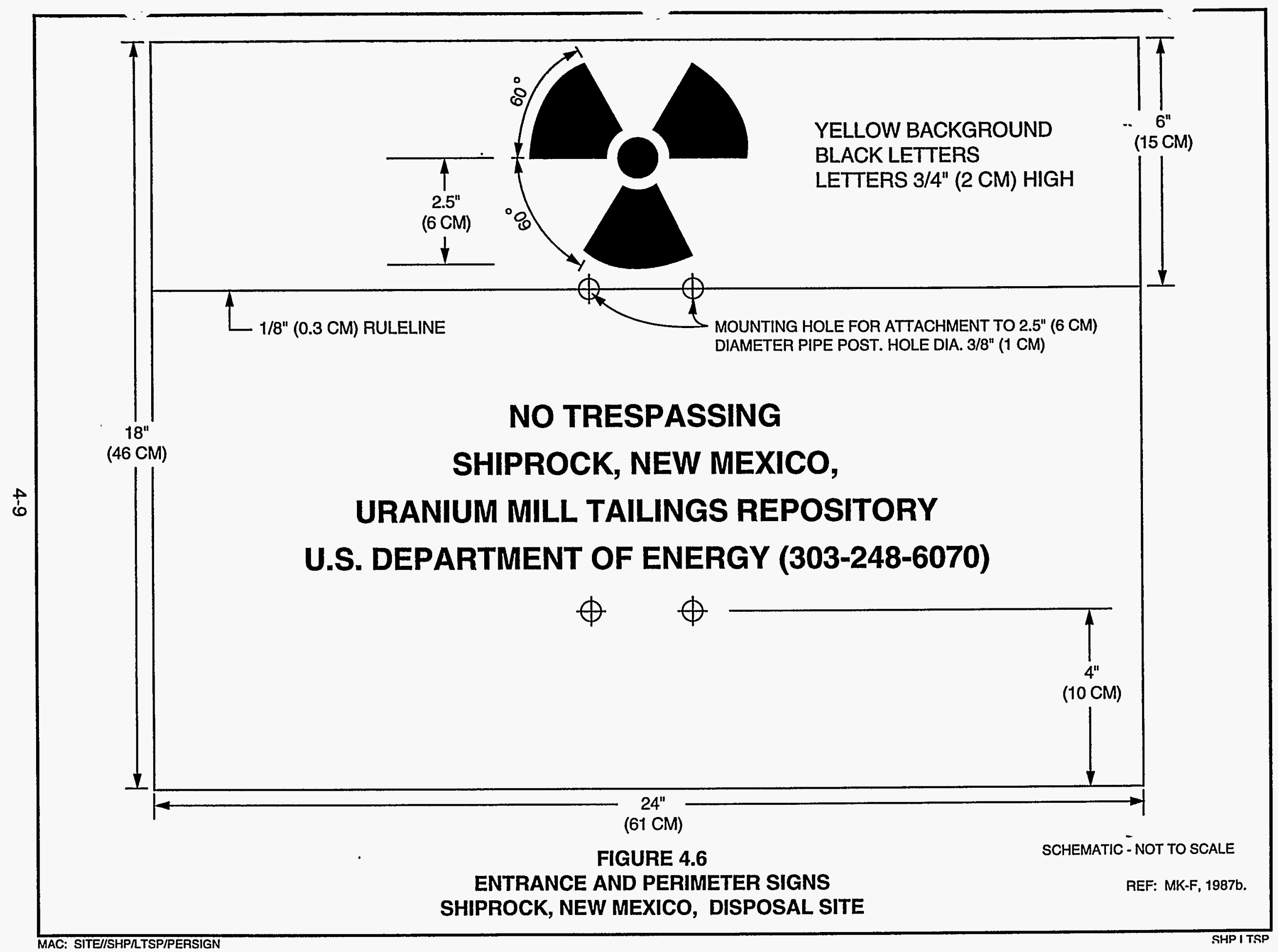




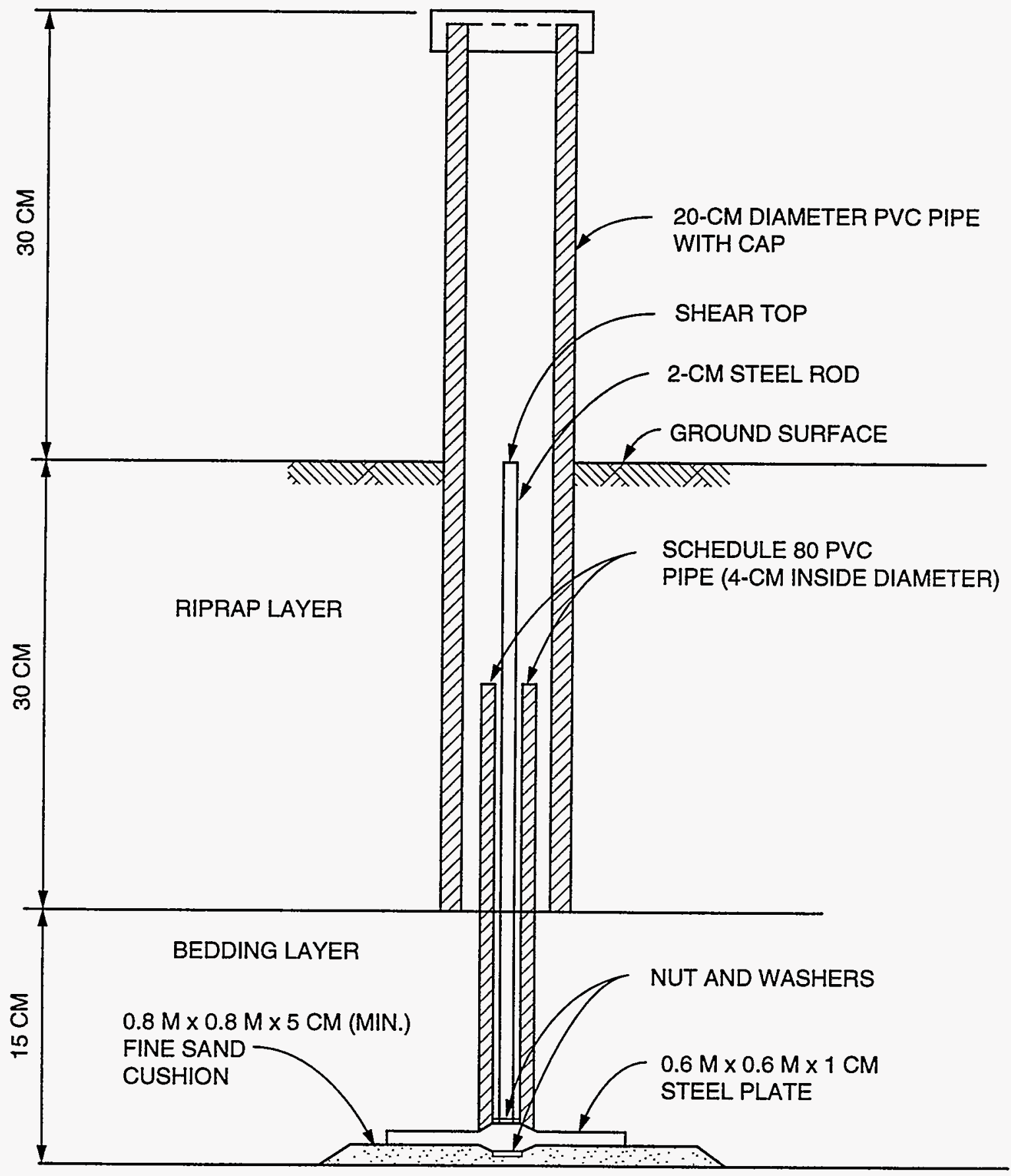

RADON BARRIER LAYER

NOTE: POLYVINYL CHLORIDE (PVC)

FIGURE 4.7

UMTRA PROJECT SETTLEMENT PLATE SHIPROCK, NEW MEXICO, DISPOSAL SITE 
Table 4.2 Survey coordinates and elevations as of October 6, 1986, for settlement plates at the Shiprock, New Mexico, disposal site

\begin{tabular}{|c|c|c|c|}
\hline \multirow[b]{2}{*}{ Feature } & \multicolumn{2}{|c|}{ Coordinates $^{\mathbf{a}}$} & \multirow{2}{*}{$\begin{array}{c}\text { Elevation } \\
\text { (ft) }\end{array}$} \\
\hline & North (N) & East (E) & \\
\hline Settlement plate no. 1 & 8171.07 & 10437.19 & 4992.77 \\
\hline Settlement plate no. 2 & 7934.33 & 10665.42 & 5001.27 \\
\hline Settlement plate no. 3 & 7650.93 & 10935.21 & 5004.34 \\
\hline Settlement plate no. 4 & 7404.21 & 11171.51 & 4993.43 \\
\hline Settlement plate no. 5 & 7999.95 & 10963.77 & 5002.33 \\
\hline Settlement plate no. 6 & 7871.11 & 11070.57 & 5001.82 \\
\hline Settlement plate no. 7 & 8152.21 & 11108.20 & 4996.92 \\
\hline Settlement plate no. 8 & 7986.09 & 11254.89 & 4995.68 \\
\hline Settlement plate no. 9 & 8280.09 & 11189.18 & 4991.60 \\
\hline Settlement plate no. 10 & 8067.71 & 11415.21 & 4990.27 \\
\hline Settlement plate no. 11 & 8444.92 & 11306.62 & 4964.21 \\
\hline Settlement plate no. 12 & 8139.78 & 11485.12 & 4979.40 \\
\hline
\end{tabular}

aSee Plate 1 for relative locations of the settlement plates. The coordinates are based on the project survey control point (N 10,000.00, E 10,000.00) located at the USBR benchmark just northeast of SM-1.

${ }^{b}$ The error factor in the elevation is $\pm 0.05 \mathrm{ft}(0.02 \mathrm{~m})$. 
standard logo cap. Each $4-\mathrm{ft}(1.2-\mathrm{m})$ long marker is set with the cap extending approximately $1 \mathrm{ft}(0.3 \mathrm{~m})$ above ground surface.

\subsubsection{Reference posts}

No reference posts have been installed at the Shiprock disposal site to help inspection teams locate boundary and survey monuments. If the monuments become difficult to locate due to shifting sands or plant growth, one 5-ft $(1.5-\mathrm{m})$ reference post may be installed in concrete at each location. 


\subsection{GROUND WATER MONITORING}

The NRC has concurred that the hydrogeology and ground water conditions at the Shiprock disposal site have been adequately characterized. It was concluded that the site is over an aquifer not useful as a source of water for drinking or any other beneficial purpose because of its poor quality, limited areal extent, and low yield (NRC, 1990; 1991). In accordance with these findings, no additional hydrogeologic investigations are planned for the disposal site and no cell performance monitoring of ground water is proposed as part of the long-term surveillance program. The hydrogeology and ground water conditions at the site are summarized below.

\subsection{GROUND WATER CHARACTERIZATION}

The DOE has identified the constituents of concern and conducted a characterization of the hydrogeologic units and the hydraulic and transport regimes at the Shiprock disposal site. Details are provided in Appendix $D$ of the Shiprock RAP (DOE, 1985) and in the Shiprock baseline risk assessment (DOE, 1993b).

\subsubsection{Hydrostratigraphy}

The disposal site is on an elevated river terrace on the southwest side of the San Juan River as described in Section 2.2.1 of this LTSP.

The terrace alluvium beneath the disposal cell is between 10 and $45 \mathrm{ft}$ ( 3 to $13 \mathrm{~m}$ ) thick. This alluvium consists of interbedded sands and silts with lenses of gravel and cobbles. The alluvium is underlain by approximately $1000 \mathrm{ft}$ $(300 \mathrm{~m})$ of Mancos Shale consisting of flat-lying beds of shales and sandy shales. The Mancos Shale is relatively impermeable at depth, but the upper 10 to $30 \mathrm{ft}(3$ to $9 \mathrm{~m})$ are discontinuously weathered and fractured. The Mancos Shale is underlain by the Dakota Sandstone and Morrison Formation.

Ground water below the disposal site occurs in the alluvium; the upper, weathered part of the Mancos Shale; in fractures or sandstone tongues in the unweathered Mancos Shale; and in the Dakota Sandstone and Morrison Formation. The ground water in the alluvium and in the upper part of the Mancos Shale is unconfined and constitutes the uppermost aquifer. Ground water in the Dakota Sandstone and Morrison Formation is confined and has a piezometric surface that is above the water table in the alluvium and upper part of the Mancos Shale. The higher piezometric head, combined with the low permeability of the unweathered Mancos Shale, will preclude movement of impacted water beneath the tailings pile into the deeper aquifers.

The terrace alluvium is recharged by precipitation. This water is perched on the Mancos Shale and moves across its surface. The surface of the Mancos Shale was eroded by the San Juan River and has shallow erosional valleys and low ridges that could cause the perched ground water to flow to the west-northwest 
(Figure 5.1). There are not enough data to develop an accurate flow map of the ground water in the terrace alluvium.

The ground water also percolates down into the upper, fractured part of the Mancos Shale. Some of this water moves horizontally along bedding planes and emerges as seep along the escarpment face immediately to the north of the disposal site. It is also anticipated that ground water in the Mancos Shale may flow below the floodplain toward the San Juan River, the local base level in the region. This water would then move up out of the Mancos Shale into the alluvium of the floodplain or directly into the river (Figure 5.2).

\subsubsection{Background ground water quality}

Monitor wells were installed to the north, east, south, and west of the disposal site to define the extent of the contaminant plume and determine background ground water quality. The ground water in all of these wells exhibits evidence of impacts by the former milling operations and/or the tailings pile. Background ground water quality is defined as the ground water quality from a hydrogeologic unit at the disposal site that has not been contaminated by uranium processing activities (Technical Approach Document) (DOE, 1989). Because the Shiprock disposal cell overlies an existing contaminant plume that resulted from surface uranium processing activities at the site between 1954 and 1968 , background ground water quality or maximum concentration limits (MCL) cannot be used to establish concentration limits to evaluate the initial performance of the disposal cell. Additional investigations will be conducted as part of the DOE's ground water restoration program (NRC, 1990; 1991).

\subsection{GROUND WATER MONITORING NETWORK}

The tailings at Shiprock were stabilized in place in accordance with the EPA standards (40 CFR Part 192), and with the concurrence of the NRC (Attachment 2). Based on the hydraulic properties of the cover design and field testing of the cover, the NRC concurred that infiltration through the cover and stabilized tailings has been reduced to the maximum extent practicable. 


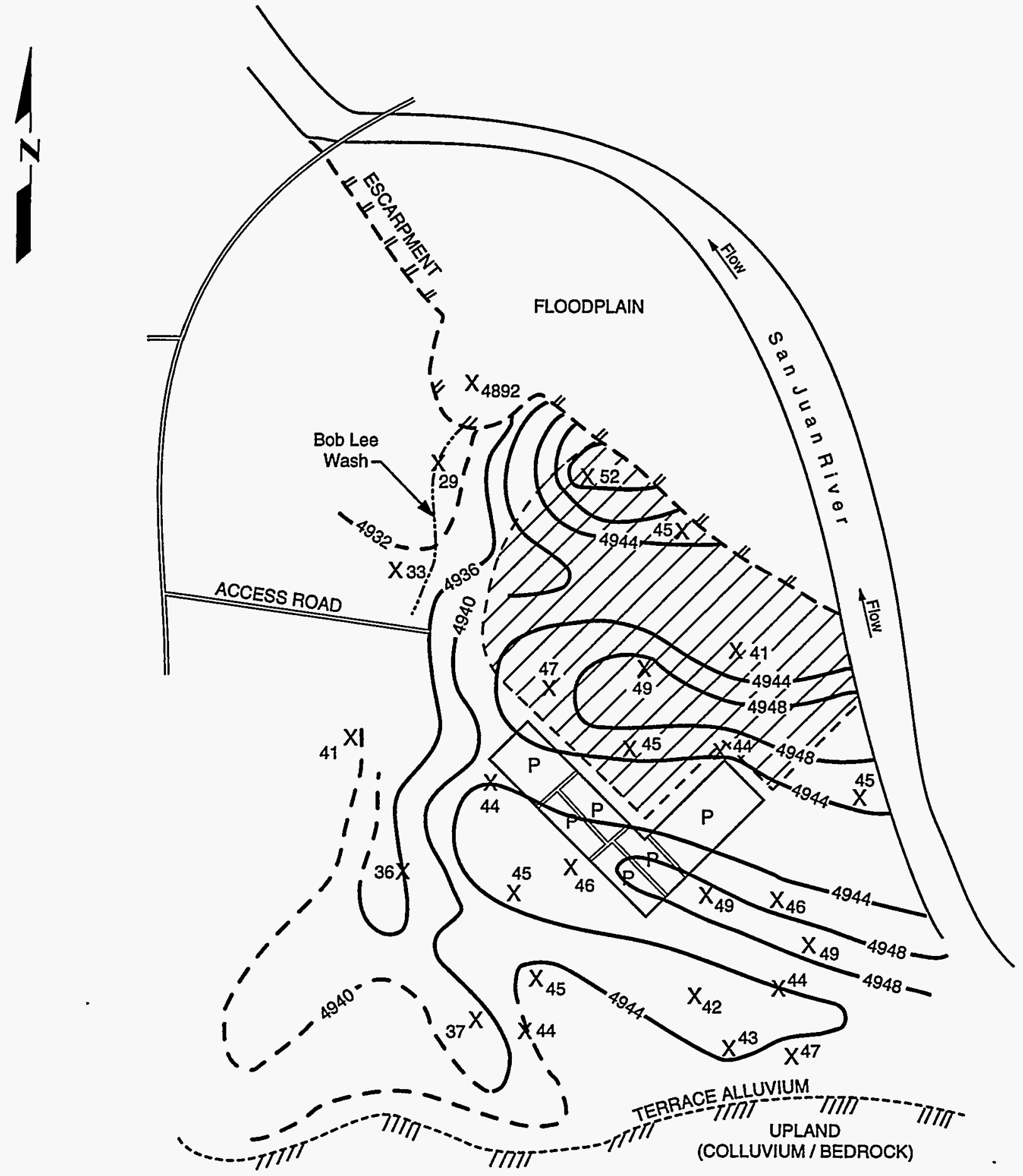

\section{LEGEND}

-4944 - BEDROCK SURFACE CONTOUR ${ }^{41} \mathrm{X}$ BEDROCK ELEVATION IN

IDD FORMER TAILINGS PILES AND MILL SITE

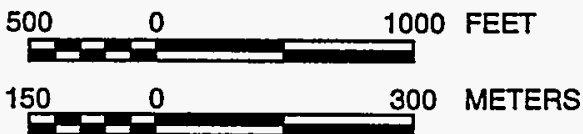

$P$ FORMER RAFFINATE POND

FIGURE 5.1

BEDROCK SURFACE CONTOURS ON TERRACE 
宽
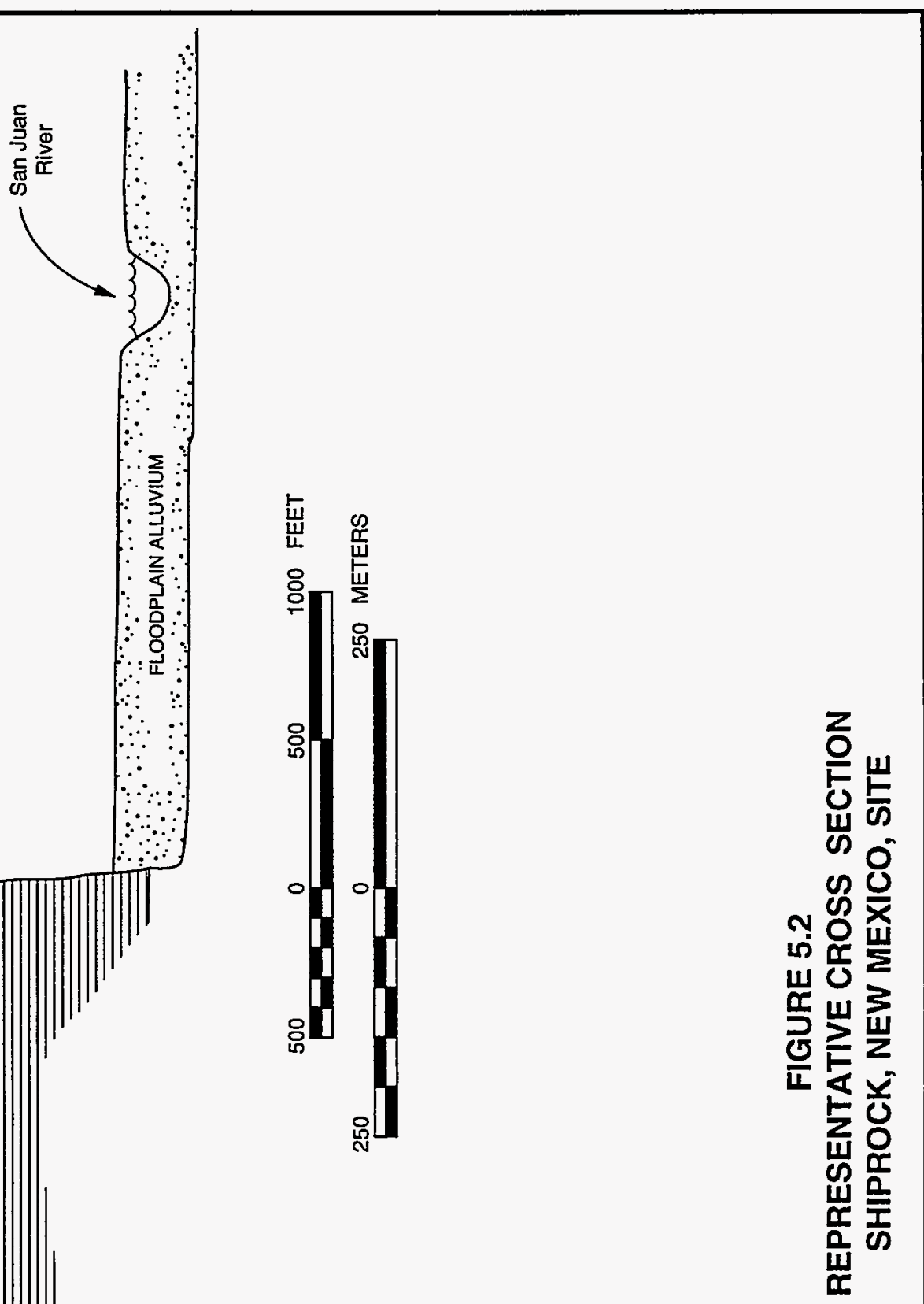

䔅

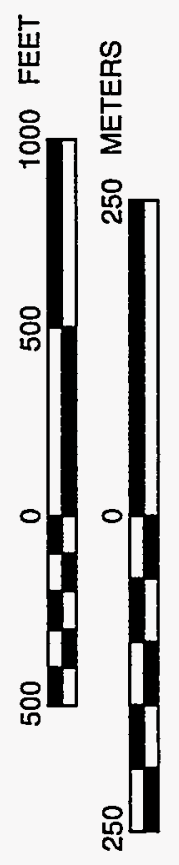




\subsection{SITE INSPECTIONS}

Inspections of the Shiprock disposal site are conducted to ensure that it continues to function as designed. The primary objective of a site inspection is to identify potential problems before extensive maintenance, corrective action, or repairs are needed. The inspection team will be knowledgeable in the processes that could adversely affect the site. A fundamental part of the inspection will be the detection and documentation of progressive change caused by slowly acting natural processes. The findings from these inspections will be compared to the initial baseline conditions to provide a basis for future inspections. The three types of site inspections are as follows:

- Annual or scheduled site inspections.

- Follow-up inspections.

- Contingency inspections.

Each site inspection will be documented by a report that identifies the findings of the inspection. Copies of the report will be submitted to the NRC and the Navajo Nation and will be placed in the Shiprock permanent site file. Annual or scheduled site inspection reports will be completed and submitted to the NRC within 90 days of the last UMTRA program site inspection of that calendar year. Follow-up or contingency inspection reports must be submitted to the NRC within 60 days of the initial report and within 60 days after any other type of inspection.

\subsection{INSPECTION FREQUENCY}

The Shiprock disposal site will be inspected annually for the first 5 years after licensing. At the end of the 5-year period, the GJPO will evaluate the need to continue annual inspections, basing its recommendation on an evaluation of the annual reports and any other reports that have been filed for maintenance or unscheduled events. If it is determined that less frequent inspections are required, the GJPO will modify the LTSP and submit it to the NRC for approval. The Navajo Nation will also receive a copy for review. Subsequent inspections will be considered a scheduled site inspection.

Site inspections at the Shiprock disposal site should preferably take place in the summer, during the growing season of volunteer plants to see if the plants are affecting the integrity of the cover and if any maintenance of the disposal cell cover is necessary.

\subsection{INSPECTION TEAM}

The inspection team will consist of a chief inspector and one or more assistants. The chief inspector will be a geotechnical engineer, a civil engineer, or an engineering geologist knowledgeable in the processes that could adversely affect the site (e.g., geomorphic agents of change). Because the Shiprock disposal site has a rock cover, a plant specialist may be required to analyze volunteer plant growth on the cover. Additionally, because of the potential for 
shifting sands and sand accumulation on the cover, a geologist may be required to document the changes and the potential long-term effects. The need for specific specialists will be determined by GJPO based on results of previous inspections.

When the team is needed for follow-up or assessment inspections, they will inciude additional technical experts appropriate to the problems under investigation.

\subsection{PREPARATION FOR INSPECTIONS}

Before each inspection, inspectors will complete the following tasks:

- Review the final LTSP, the permanent site file, the previous site inspection report(s) and site inspection map(s), and all maintenance or corrective action reports.

- Prepare the site inspection checklist based on previous inspections or repairs; incorporate any needed modifications.

- Verify and update the names and telephone numbers of all parties with whom access or notification agreements have been executed.

- Verify the DOE 24-hour telephone number and appropriate tribal agency telephone numbers and contacts. Arrange to change all signs, as needed.

- Schedule the site inspection.

- Notify the NRC and Navajo Nation representatives so that they may attend the inspection if they so choose.

- Notify NECA.

- Assemble the equipment needed for the inspection.

- Adjust the Brunton compass's magnetic declination for that of the Shiprock area (currently approximately 12 degrees east of true north).

\section{$6.4 \quad$ SITE INSPECTION AND INSPECTION CHECKLIST}

The site inspection will cover the disposal site area, the disposal cell, and the immediate off-site areas. All site inspection activities and observations should be recorded and described using the as-built drawings, site inspection checklist (Attachment 5), site inspection map, field notebook, and photographs. Observations and photographic stations should be recorded on the field maps. After the inspection is complete, these maps will be drafted and retained in the Shiprock permanent site file. 
The initial site inspection checklist (Attachment 5) is a guideline for the inspectors. After each inspection is complete, the checklist will be revised to include new information or to delete items that are no longer pertinent. Revisions to the checklist will be documented in the inspection report.

A photographic record of each site inspection must be obtained. Disposal site conditions should be documented by ground photographs to record developing trends and to enable the DOE to evaluate the need for and extent of future activities. Any site feature or condition that requires the inspectors to make a written comment, explanation, or description will be photographed, if possible. A site inspection photo log will be used to record the photographs (Attachment 4). All features will be photographed and recorded as specified in Section 3.6. The inspectors may determine the number of photographs, the view angles, and the lenses used to ensure that sufficient photographs are taken for agency review.

\subsubsection{Off-site areas}

The area within a maximum of $0.25 \mathrm{mi}(0.4 \mathrm{~km})$ of the center of the disposal site will be surveyed for evidence of land-use changes that indicate increased human activity (i.e., greater probability of intrusion onto the site). Shifts in the channel of the San Juan River or excessive sloughing along the escarpment that could affect the integrity of the disposal cell will also be noted. The base of the escarpment will be traversed from the eastern end of the floodplain to Bob Lee Wash (Figure 2.1), and signs of seepage will be noted.

\subsubsection{On-site areas}

The integrity of the disposal cell site will be evaluated by a series of transects around the perimeter of the disposal site; along the base, crest, and sideslopes of the disposal cell; and in and around the diversion channels. Sufficient transects must be walked so that the disposal site area is thoroughly covered and inspected. Diagonal transects of the crest will be made, and the edge of the crest will be walked. Additional transects, at approximately $50-\mathrm{ft}(46-\mathrm{m})$ intervals, will be walked along the sideslopes. Transects along the entire length of each diversion channel will be made to determine whether the channels have been functioning and can be expected to continue to function as designed.

At a minimum, the site perimeter and site area transects will be checked for damage or disturbance to the following features:

- Site perimeter roads.

- Fences, gates, and signs.

- Permanent site surveillance features.

- Site area vegetation or volunteer plant growth.

- Sedimentation or erosion.

- Drainage ditches. 
All permanent surveillance features (Section 4.0 ) will be examined for evidence of disturbance. Naturally occurring changes in site features will be noted and assessed for the need for maintenance or corrective action. If disturbance or damage to site surveillance features is evident, a recommendation for maintenance or repair will be made.

Transects along the engineered component (diversion channels, cell sideslopes, cell crest, and cover) will be walked along their complete length and examined for evidence of the following:

- Structural instability due to differential settlement, subsidence, cracking, sliding, or creep.

- Erosion as evidenced by the development of rills or gullies.

- Sedimentation or debris.

- Rapid deterioration of the rock cover caused by weathering or erosion.

- Removal of rock or other disposal cell material.

- Seepage.

- Intrusion (inadvertent or deliberate) by humans or animals.

- Animal burrowing.

- Vandalism.

- Development of trails from human or animal activity.

- Volunteer plant growth.

\subsubsection{Modifying processes}

At the Shiprock disposal site, processes of concern include settling, subsidence, slumping, plant and animal intrusion, erosion (gullying), and eolian sedimentation. If any modifying features are observed during the inspection, the following data should be recorded on the inspection checklist:

- Evidence of settlement or sliding, including the presence of bulges or depressions, cracks, or scarps.

- Extent of the area affected, stability, and nature of movement.

- Number of modifying features, spacing, length, depth, and width.

- Related erosional features. 
- Patterns of occurrence.

- Plant or animal species found at the site.

- Location and density of volunteer plant growth.

If new conditions requiring continuing observation, monitoring, or immediate action are discovered during the inspection, the inspector should quantify the observed conditions and identify the appropriate level of action for subsequent inspections.

\subsection{SITE INSPECTION MAP}

A new Shiprock disposal site inspection map will be prepared after each scheduled inspection using the Shiprock disposal site map (Plate 1) as a base. This map must include the following:

- Inspection transects.

- Photographic locations.

- Locations and descriptions of any new, anomalous, or unexpected features.

- Features identified during previous inspections for observation or monitoring.

- Inspection date.

\subsection{REPORTING REQUIREMENTS}

Upon completion of the field inspection, Section $D$ of the site inspection checklist (Attachment 5) will be completed and the certification statement must be signed. Overlays for the as-built drawings or revised drawings will be developed, noting any potential problems or other site conditions that may require attention. The revised drawings will be labeled with the type of site inspection and the date the site inspection was performed.

All photographs will be logged on a site inspection photo log (Attachment 4). A separate photo log will be completed for each roll of film exposed, with an entry for each photograph. The completed photo logs should be attached to the inspection checklist and paginated accordingly.

Documentary evidence of anomalous, new, or unexpected conditions or situations must be included to record developing trends and to enable the responsible agency to make reasonable decisions concerning follow-up inspections, custodial maintenance, repair, and corrective action. Photographs may be considered documentation.

A site inspection report will be prepared describing surveillance activities at the disposal site. The inspection report will include the information identified in the LTSP guidance document (DOE, 1992a). At a minimum, the report will include a narrative, inspection checklists, photographs and photo logs, maps, field notes, inspector qualifications, and a certification of inspection. All problems, 
active or potential, will be identified and described in the report, along with recommendations for follow-up inspections, custodial maintenance or repair, or corrective action, if required.

Appendix A, Criterion 12 of 10 CFR Part 40 requires that the DOE submit the results of all routine site inspections to the NRC within 90 days of the last UMTRA Project site inspection for that calendar year. Copies will also be provided to the Navajo Nation. A copy of all site inspection reports will be maintained in the Shiprock permanent site file. 


\subsection{UNSCHEDULED INSPECTIONS}

The need for an unscheduled inspection may be triggered by reports or information indicating that site integrity has been or may be compromised.

\subsection{FOLLOW-UP INSPECTIONS}

Follow-up inspections are used to investigate and quantify specific problems detected during a scheduled site inspection, ground water sampling event, special study, or other DOE activity. They are needed to determine if processes currently active on or near the site threaten site security or stability and to evaluate the need for immediate custodial maintenance, repair, or corrective action.

Follow-up inspections should be made by technical specialists in a discipline appropriate to the problem (e.g., a soils scientist or geomorphologist to evaluate erosion processes).

The first step of the follow-up procedure is an on-site visit to determine the need for definitive tests or studies. Additional visits may be scheduled if more data are needed to draw conclusions and recommend corrective action. If maintenance, repair, or corrective action is warranted, the DOE will notify the NRC and the Navajo Nation as specified in Section 9.0.

\subsection{CONTINGENCY INSPECTIONS}

Contingency inspections are unscheduled inspections ordered by the DOE when it receives information indicating that site integrity has been or may be threatened. Examples of events that could trigger contingency inspections include reports of severe vandalism, intrusion by humans or livestock, severe rainstorms, or unusual events such as tornados or earthquakes.

An assessment of each unusual event must be submitted to the NRC within 60 days of the initial report that damage or disruption has occurred at the Shiprock disposal site (10 CFR Part 40). The Navajo Nation will receive a copy of this report. At a minimum, this report must include the following:

- A description of the problem.

- A preliminary assessment of the maintenance, repair, or corrective action.

An assessment of each unusual event must be submitted to the NRC within 60 days of the initial report that damage or disruption has occurred at the Shiprock disposal site (10 CFR Part 40). The Navajo Nation will receive a copy of this report. At a minimum, this report must include the following:

- A description of the problem. 
- A preliminary assessment of the maintenance, repair, or corrective action required.

- Conclusions and recommendations.

- Assessment data, including field and inspection data, and photographs.

- Names and qualifications of the field inspectors.

A copy of the report and all other data and documentation will be maintained in the Shiprock permanent site file. The annual report to the NRC will include the results of these contingency inspection reports. If appropriate, the annual (or scheduled) Shiprock disposal site inspection report will also contain the results of these inspections.

After reviewing the preliminary inspection/assessment report, the DOE must submit a corrective action plan for NRC approval and to the Navajo Nation within the 60-day period required by 10 CFR Part 40 . Based on the findings of these reports, the GJPO will complete corrective action following the guidance for implementing corrective action described in Section 9.0. 


\subsection{CUSTODIAL MAINTENANCE AND REPAIR}

Custodial maintenance will be performed as needed at the Shiprock disposal site. In general, the decision to conduct maintenance or repair will be based on the results of scheduled site inspections, follow-up inspections, or contingency inspections.

\subsection{PLANNED MAINTENANCE}

Planned maintenance at the Shiprock disposal site will be limited to a spraying program to control unwanted vegetation growth on the disposal cell. Due to the arid conditions at the site and the sporadic frequency and amount of rainfall, this spraying will occur as needed. Vegetation growth will be monitored during inspections conducted during the growing season. If significant vegetation is found, a maintenance visit to apply a herbicidal spray will be scheduled.

\subsection{UNSCHEDULED MAINTENANCE OR REPAIR}

Unscheduled custodial maintenance activities that may be required at the Shiprock disposal site include the following:

- Repair of gates and fences.

- Replacement of perimeter warning signs.

- Reestablishment of survey control and boundary monuments and erosion control markers.

- Eradication of deep-rooting trees and shrubs.

- Removal of tumbleweeds or other debris from the diversion channel or from around fences.

- Control of burrowing animals.

- Placement of fill in gullies or rills.

- Replacement of erosion barrier rock cover materials.

For these types of custodial actions, the GJPO will prepare a purchase order and statement of work (SOW) (including subcontractor qualifications) authorizing the repair.

If problems are identified that may affect the integrity of the disposal cell or compliance with 52 FR 36000 , the NRC must approve the recommended action in advance. The action will be treated as corrective action. 


\subsection{CERTIFICATION AND REPORTING REQUIREMENTS}

The following information on unscheduled maintenance or repair must be provided in the Shiprock site inspection report and included in the annual report to the NRC:

- Summary of work required.

- Work order, purchase order, or SOW.

- Contractor qualifications, if applicable.

- Contractor documentation of completion of work.

- DOE certification of completion of work.

After the work is completed, the contractor must submit verification of the completed work and/or a written report if the action is considered significant. The DOE will inspect the site, as necessary, and review the report before certifying that all work was completed in accordance with all required specifications. Copies of all records, documentation, and certifications must be included in the Shiprock permanent site file. Copies of all relevant documentation will be transmitted to the NRC and the Navajo Nation. 


\subsection{CORRECTIVE ACTION}

If natural or unforeseen events threaten the stability of the disposal cell corrective action could include temporary emergency measures. In addition, the DOE would evaluate the factors that caused the problem to ensure that recurrence is minimized or avoided.

When a potential problem is identified, the DOE will notify the NRC and the Navajo Nation and submit an inspection/preliminary assessment report for NRC and the Navajo Nation to review no more than 60 days after the problem is identified. The preliminary assessment report will evaluate the problem and recommend the next step (e.g., immediate action or continued evaluation). After the NRC and Navajo Nation review the report and recommendations, the DOE will develop a corrective action plan for NRC approval. The DOE may combine the inspection and recommendation in one report, depending on the severity of the problem. Once the NRC approves the corrective action, the DOE will implement the plan. Figure 9.1 illustrates the general sequence of events in the corrective action process. Figure 9.2 identifies the key elements in the corrective action process.

NRC regulations do not stipulate a time frame for implementing corrective action. However, the EPA ground water regulations [40 CFR \$192.02(c)] require that a corrective action program begin operation no later than 18 months after confirmation of an exceedance at a disposal cell. Assessing the extent of a problem and developing a corrective action plan will not be considered initiation of the corrective action program. Section 9.0 of the UMTRA LTSP guidance document (DOE, 1992a) contains details on corrective action.

\section{$9.1 \quad$ PROBLEM IDENTIFICATION}

Site inspections by qualified inspectors and routine custodial maintenance are designed to identify problems at the developmental stage, eliminating the need for corrective action. However, extreme natural events, vandalism, and unanticipated events may create the need for additional data or evaluative monitoring to assess whether uncorrected problems would threaten site integrity. An on-site inspection/preliminary assessment would include, but not be limited to, the following:

- Quantifying the nature and extent of the problem.

- Reevaluating the engineering design parameters germane to the problem.

- Establishing a data collection and/or evaluative monitoring program to quantify the magnitude of the problem.

Because of the standards on which the Shiprock disposal site was designed, it is considered extremely unlikely that problems will occur. However, some situations that may require corrective action at the Shiprock disposal site include the following: 


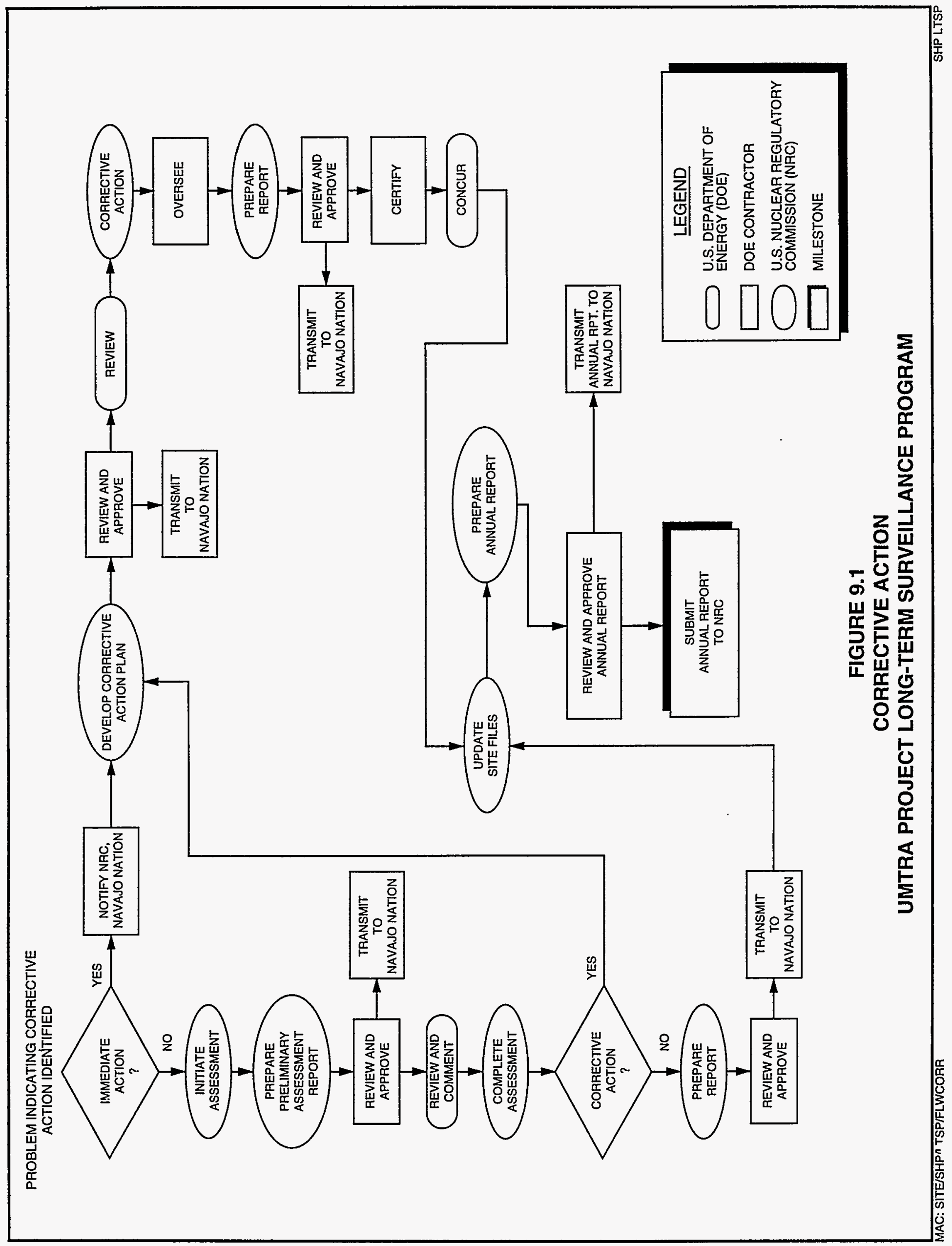




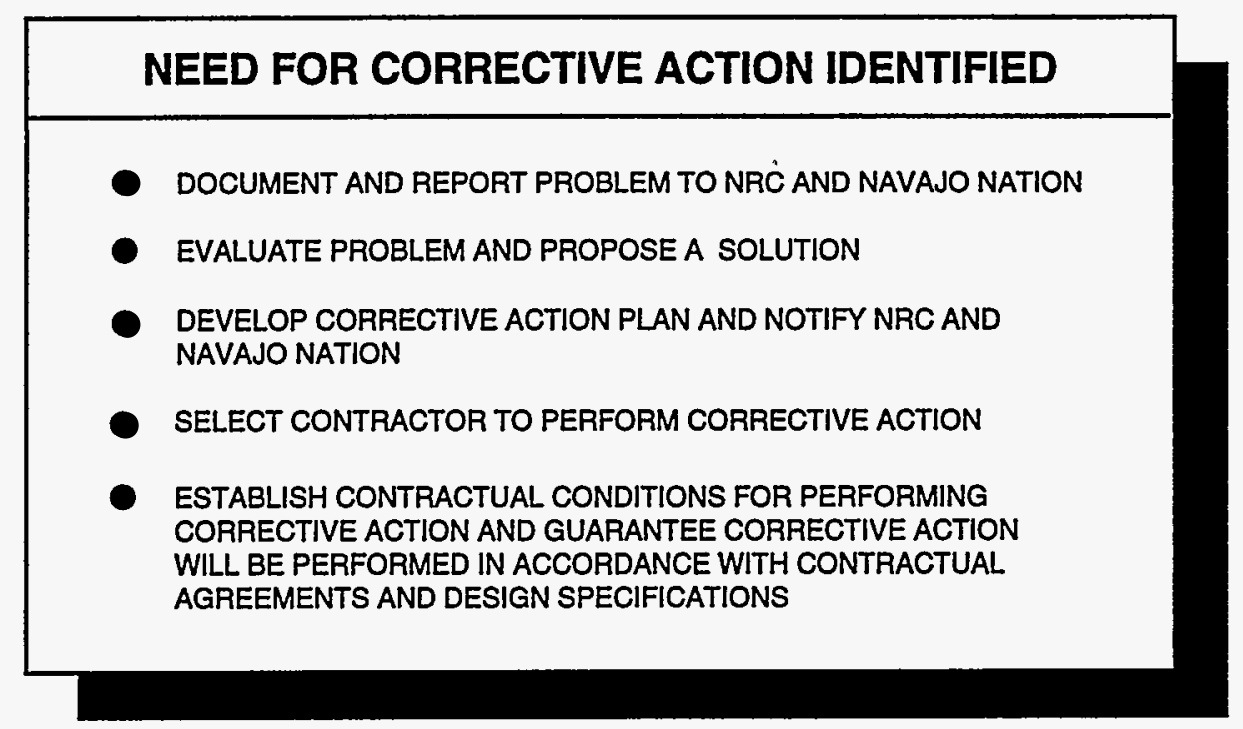

\section{IMPLEMENTATION}

- MONITOR PROGRESS OF CORRECTIVE ACTION

- VERIFY COMPLETION OF CORRECTIVE ACTION

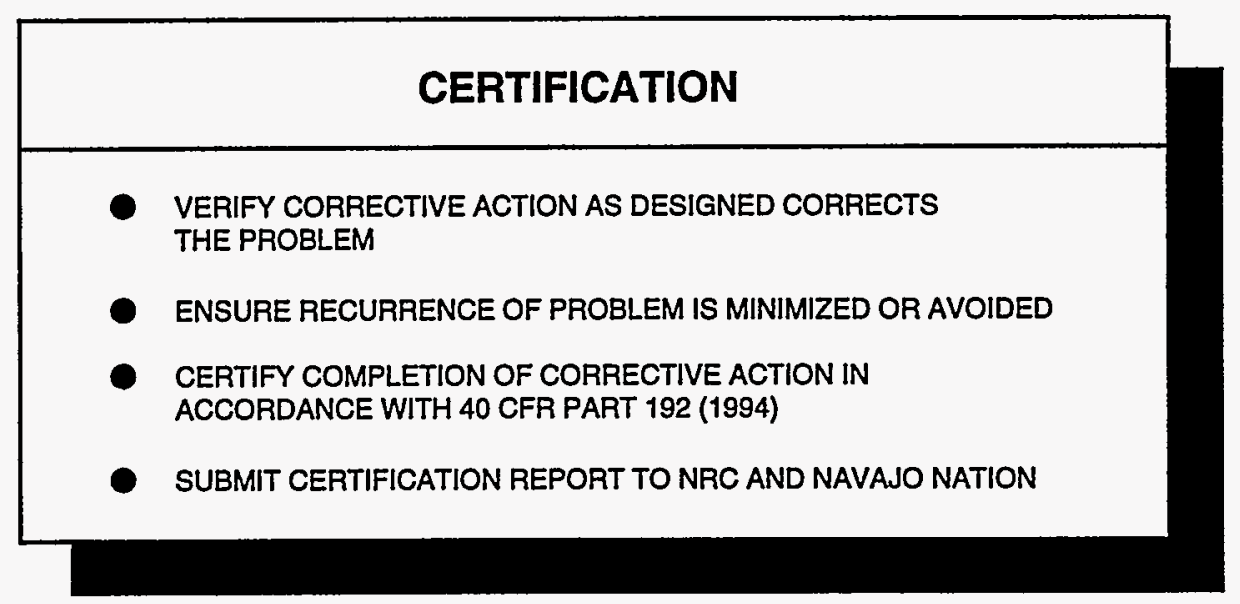

REF: DOE, 1992a.

FIGURE 9.2

KEY ELEMENTS IN THE CORRECTIVE ACTION PROCESS 
- Unforeseen subsidence of the disposal cell or its foundation.

- Gullies that have cut through, or are threatening to cut through, the outer cover.

- Slides on the slopes of the disposal cell.

- Significant deterioration of the rock cover.

- Cracks that extend deeply into the disposal cell cover.

- Persistent animal burrowing or excessive vegetation growth on the disposal cell.

- Removal of some of the disposal cell material by humans or natural events such as flash floods.

- Significant erosion at the edge of the escarpment.

- Increased seepage along the escarpment or deterioration of the surface water quality.

\subsection{IMPLEMENTATION OF CORRECTIVE ACTION}

The DOE will define detailed procedures for implementing the corrective action when a corrective action becomes necessary. Implementing a corrective action program could be carried out in two or more steps. If a preliminary assessment recommends a phased response to the problem, a program of additional characterization with additional data collection and/or evaluative monitoring would be implemented to draw conclusions and recommend the appropriate corrective action.

\subsection{CERTIFICATION AND REPORTING REQUIREMENTS}

The DOE will prepare progress reports on each corrective action, while it is underway or under evaluation. The NRC will receive a copy of each report, or the report will be attached to the annual report. The NRC will be informed of all potential problems and the solutions. A copy of all reports will also be provided to the Navajo Nation.

After corrective action is complete, all work will be certified in accordance with EPA standards. A copy of the accepted certification statement will become part of the Shiprock permanent site file, as will all reports, data, and documentation generated during the corrective action. 


\subsection{RECORD KEEPING AND REPORTING REQUIREMENTS}

The DOE will maintain the Shiprock permanent site file containing all information needed to prepare for and conduct site surveillance. Carefully compiled, complete, and accurate reports of site surveillance activities will be maintained in accordance with archival procedures set forth in 41 CFR Part 101 (1994) and 36 CFR Part 1220-1238 (Subchapter B - Records Management) (1994).

As required by 55 FR 45591 (1990), the DOE will provide an annual report to the NRC documenting the results of the long-term surveillance program. Copies of the annual report will be provided to the Navajo Nation and will be added to the Shiprock permanent site file. The annual reports and supporting documentation in the permanent site file will accomplish the following:

- Document the history of disposal site performance.

- Demonstrate to the NRC that licensing provisions were met.

- Provide the DOE and the NRC with the information needed to forecast future site surveillance and monitoring needs.

- Provide to the public information that site integrity has been maintained.

\subsection{RECORDS}

The GJPO will maintain the Shiprock permanent site file in Grand Junction, Colorado. All original deeds, custody agreements, and other property documents will be kept at the DOE Facilities and Property Management Division, Albuquerque, New Mexico. Copies of the documentation will also be maintained in GJPO files.

Surveillance and maintenance documentation maintained at the GJPO will exist as a record collection separate from the UMTRA Project Document Control Center. As such, the records will be handled in accordance with DOE Order 1324.2A, Records Disposition, to ensure proper handling, scheduling, and disposition of the documents.

All information will be available for NRC and public review. The Shiprock permanent site file will include the following:

- Licensing documentation.

- Site-specific LTSP.

- Disposal site legal description, title, custody documentation, and cooperative agreements. 
- Interagency agreements, authorizations, and access agreements.

- Documentation of rights of entry.

- Environmental assessments and findings of no significant impact.

- Disposal site characterization report.

- Final RAP and final design for construction.

- Pertinent design and construction documents and drawings.

- Site certification report (certification summary, completion, and final audit reports).

- As-built drawings.

- Site atlas (vicinity, topographic, and base maps).

- Baseline and aerial photographs.

- Ground water monitoring reports and records.

- Additional monitoring reports and records.

- Monitor well permits and abandonment records.

- Annual reports to the NRC.

- Annual inspection reports and records.

- Follow-up or contingency inspection preliminary assessments, reports, and records.

- Custodial maintenance or repair reports and records.

- Corrective action plans, reports, and records.

- Quality assurance program plan.

Attachment 3 provides an index of the documentation contained in the permanent site file that will be transferred to the GJPO for the long-term surveillance program.

\subsection{REPORTS}

The GJPO will provide an annual report to the NRC, documenting the results of the annual site inspections and any other activities conducted in conjunction 
with the long-term surveillance program. Criterion 12, Appendix A, 10 CFR Part 40 (1994) stipulates that the annual report be submitted no more than 90 days after the date of the last UMTRA Project site inspection for that calendar year.

The GJPO will also submit reports to the NRC and Navajo Nation documenting follow-up or contingency inspections and any corrective action plans. If any unusual damage or disruption is discovered, Criterion 12, Appendix A, 10 CFR Part 40 (1994) requires that all preliminary inspection reports be submitted within 60 days of the discovery.

The results of the ground water monitoring program for the floodplain area will be contained in separate reports not related to the long-term surveillance program. Ground water monitoring specific to disposal site surveillance was determined to be inapplicable to the Shiprock disposal site. 


\subsection{EMERGENCY NOTIFICATION AND REPORTING}

The Shiprock disposal cell was designed to comply with 40 CFR Part 192 (1994) with minimum maintenance and oversight for a period of 1000 years, or at least 200 years. However, unforeseen events could create problems that may affect the disposal cell's ability to remain in compliance with 40 CFR Part 192 (1994). Therefore, the DOE has requested notification from state and federal agencies of any purposeful intrusion or damage at the Shiprock disposal site as well as the occurrence of an earthquake, tornado, or flood in the Shiprock disposal site area.

\subsection{AGENCY AGREEMENTS}

The DOE has negotiated formal agreements with the Shiprock Navajo Police, the Bureau of Reclamation (Durango, Colorado), the USGS National Earthquake Information Center (Denver, Colorado), and the New Mexico State Office of the National Weather Service. Copies of the agreements are presented in Attachment 6 . The designated point of contact for emergency notification is the GJPO 24-hour telephone line [(303) 248-6070]. This number is posted on the Shiprock disposal site entrance signs and perimeter signs so the public can notify the DOE, if problems are discovered.

In accordance with the agreements, the UMTRA Project Office will be the designated facility contact until the Shiprock site is brought under the NRC general license. After that, the designated facility contact will be the GJPO.

Response letters from all of the agencies will be kept in the permanent site file. Contact lists and telephone numbers for all agencies and parties with whom the DOE has entered into agreements will be updated annually, in conjunction with the site inspection, for inclusion in the disposal site inspection report.

\subsection{UNUSUAL OCCURRENCES}

The DOE has requested that the GJPO be notified of unusual occurrences in the disposal site area that may affect the surface or subsurface stability. The Shiprock Navajo Police agreed to notify the GJPO if anything out of the ordinary (i.e., human intrusion, fire) is observed by the staff or reported to the office (Attachment 6).

The DOE has requested that the GJPO be notified if a dam failure or a largescale release due to a flood event greater than the outflow capacity of Navajo Dam is imminent. The Bureau of Reclamation agreed to notify the GJPO if a dam failure or a large-scale release due to a flood event greater than the outflow capacity of the Navajo Dam is imminent (Attachment 6). 


\subsection{EARTHQUAKES}

The DOE subscribes to the U.S. Geological Survey (USGS) Early Warning Service for notification of when an earthquake of sufficient magnitude to threaten a disposal site could occur. This service provides data on the magnitude of the event and the location of the epicenter.

The USGS National Earthquake Information Center agreed to notify the DOE GJPO if a seismic event(s) occurs that fits any of the following descriptions (Attachment 6):

- Any earthquake of magnitude 3.0 or greater, within 0.3 degree (about $20 \mathrm{mi}$ [30 km]) of the site.

- Any earthquake of magnitude 5.0 or greater, with 1.0 degree (about $70 \mathrm{mi}$ [110 km]) of the site.

\subsection{METEOROLOGICAL EVENTS}

Presently, San Juan County (like nearly all of New Mexico) has no weather radar coverage. Consequently, severe weather often goes undetected. However, severe weather reports that come to the attention of the National Weather Service after the fact are included in the "Storm Data" published monthly by the National Climatic Data Center in Asheville, North Carolina. The problem of inadequate radar coverage for San Juan County will be diminished with the advent of the new NEXRAD, WSR-88D doppler system at Albuquerque, New Mexico, in 1994 (Attachment 6). 


\subsection{QUALITY ASSURANCE}

The GJPO is responsible for developing QA procedures specific to the UMTRA Project long-term surveillance program. The GJPO Long-Term Surveillance Program Quality Assurance Program Plan (DOE, 1992c) specifies requirements for the following:

- Program planning.

- Program activities, including inspections, site maintenance, corrective action, and emergency responses.

- Monitoring, if required.

- Personnel qualifications and training.

- Program surveillance and audits.

- Analytical QA.

- Analytical data validation.

All site inspections, monitoring data, records, photographs, maps, and other information related to the long-term surveillance program for the Shiprock disposal site are subject to formal and unannounced audits by the DOE UMTRA Project Office or the NRC. Specific QA criteria have already been developed for aerial photographs (DOE, 1992a).

\subsection{GROUND WATER MONITORING}

Ground water monitoring will not be performed at the Shiprock disposal site. Therefore, no QA activities specific to ground water monitoring will apply to the Shiprock long-term surveillance program. 


\subsection{PERSONNEL HEALTH AND SAFETY}

DOE Order 5480.1B, Environment, Safety and Health Program for DOE Operations, establishes personnel health and safety procedures for all DOE operations. After a disposal site is licensed and transferred to the GJPO, health and safety procedures for GJPO personnel and GJPO subcontractors will be the responsibility of the GJPO. The GJPO will determine health and safety requirements for its personnel in accordance with applicable orders and federal regulations. Because the disposal cell was constructed to control radium-226 and radon-222 releases from the residual radioactive material to within regulatory standards, (52 FR 36000 (1987)); (40 CFR \$192.02(a)(1994)) radiation exposure tracking and dosimetry badges are not needed.

\subsection{HEALTH AND SAFETY}

The inspector's health and safety training and certifications, the locations and telephone numbers for emergency medical and law enforcement facilities, and the facility contact 24-hour telephone number should be verified before each site inspection.

Specific safety concerns at the Shiprock disposal site include ponded water; slip, trip, and fall hazards; animal, snake, and insect bites; heat and cold stress; fire hazards; punctures and cuts; and driving hazards.

\section{Emergency medical and law enforcement}

Local emergency medical and law enforcement agencies have been briefed on the scope of work at the Shiprock disposal site during the long-term surveillance and maintenance phase. The pertinent 24-hour emergency numbers are as follows:

- Fire: (505) 368-4333.

- Hospital: (505) 368-4971.

- Ambulance: (505) 368-4971, ext. 660.

- Police/Sheriff: (505) 368-4383.

These agencies can also be contacted by dialing 911 .

The nearest phone is at the NECA office on land northwest and adjacent to the disposal cell.

The nearest hospital with an emergency room is the Shiprock Indian Health Services Hospital in Shiprock [phone number (505) 368-4971]. This hospital also has a trauma center. The hospital is on the west side of U.S. Highway 666 , approximately $0.5 \mathrm{mi}(0.8 \mathrm{~km})$ north of the intersection of U.S. Highway 64 and U.S. Highway 666 in the center of Shiprock. 
The San Juan Hospital is in Farmington, New Mexico Iphone number (505) 325-5011]. Directions to the hospital from the site are as follows:

- Drive west on the gravel road from the site to U.S. Highway 666 .

- Turn north on U.S. Highway 666 and drive into Shiprock.

- Turn east on U.S. Highway 64 in Shiprock and drive approximately $30 \mathrm{mi}$ $(48 \mathrm{~km})$ (45 minutes) to Farmington.

- Coming into Farmington, turn south on State Highway 371.

- The hospital is on the corner of State Highway 371 and West Maple Street.

\subsection{REPORTABLE INCIDENTS}

The inspection team should be briefed by the GJPO health and safety officer on potential site hazards and other requirements before site inspections or visits.

In accordance with DOE Order 5000.3B, Occurrence Reporting and Processing of Operations Information, any accident, injury, or environmental event (e.g., tornado, flood) occurring during the site inspection is a reportable incident. The condition or event will be reported to the GJPO facility manager or designated contact within 8 hours of occurrence. The GJPO facility manager's 24-hour telephone number for reporting an incident is (303) 248-6070. 


\subsection{LIST OF CONTRIBUTORS}

The following individuals contributed to the preparation of this report.

\begin{tabular}{ll}
\hline Name & Contribution \\
\hline C. Silva & Overall document responsibility; authorship \\
A. Holm, L. Pinkel, J. Senger, & Document review \\
L. Ulland & \\
A. Groffman & Geochemistry \\
G. Hartmann & Engineering design \\
D. Tarbox & Hydrology, hydrogeology \\
P. Martinez & Real estate \\
L. Keith & Text processing \\
B. Harvey & Graphic design \\
D. Minchow & Technical editing \\
\hline
\end{tabular}




\subsection{REFERENCES}

DOE (U.S. Department of Energy), 1993a. Licensing Plan for UMTRA Project Disposal sites, final, September 1993, DOE/AL/62350-9F, DOE UMTRA Project Office, Albuquerque Operations Office, Albuquerque, New Mexico.

DOE (U.S. Department of Energy), 1993b. Baseline Risk Assessment of Groundwater Contamination at the Uranium Mill Tailings Site Near Shiprock, New Mexico, DOE/AL/62350-48D, DOE UMTRA Project Office, Albuquerque Operations Office, Albuquerque, New Mexico.

DOE (U.S. Department of Energy), 1992a. Guidance for Implementing the UMTRA Project Long-term Surveillance Program, UMTRA-DOE/AL-350125.0000, Revision 1, final, DOE UMTRA Project Office, Albuquerque Operations Office, Albuquerque, New Mexico.

DOE (U.S. Department of Energy), 1992b. 1991 Annual Prelicensing Inspection of the Shiprock, New Mexico, UMTRA Project Disposal Site, DOE/ID/12584-102, prepared for the U.S. Department of Energy by Chem Nuclear Geotech, Inc., DOE Grand Junction Projects Office, Grand Junction, Colorado.

DOE (U.S. Department of Energy), 1992c. Long-Term Surveillance and Maintenance Program Quality Assurance Program Plan, P-GJPO-152, July 1992, prepared for the U.S. Department of Energy by Chem Nuclear Geotech, Inc., DOE Grand Junction Projects Office, Grand Junction, Colorado.

DOE (U.S. Department of Energy), 1989. Technical Approach Document, UMTRADOE/AL-050425.0002, DOE UMTRA Project Office, Albuquerque Operations Office, Albuquerque, New Mexico.

DOE (U.S. Department of Energy), 1985. Remedial Action Plan and Site Conceptual Design for Stabilization of the Inactive Uranium Mill Tailings Site at Shiprock, New Mexico, UMTRA-DOE/AL-050504.0039, prepared by the U.S. Department of Energy (with subsequent modifications), UMTRA Project Office, Albuquerque Operations Office, Albuquerque, New Mexico.

DOE (U.S. Department of Energy), 1984. Environmental Assessment of Remedial Action at the Shiprock Uranium Mill Tailings Site, Shiprock, New Mexico, DOE/EA0232, DOE UMTRA Project Office, Albuquerque Operations Office, Albuquerque, New Mexico.

DOE (U.S. Department of Energy), 1983. Cooperative Agreement Between the United States Department of Energy and the Navajo Nation, DOE Cooperative Agreement Number DE-FC04-83AL16258, U.S. Department of Energy, Albuquerque Operations Office, Albuquerque, New Mexico. 
FBDU (Ford, Bacon and Davis Utah, Inc.), 1981. Engineering Assessment of Inactive Uranium Mill Tailings, Shiprock Site, Shiprock, New Mexico, DOE/UMT-0104 FBDU 360-02 UC 70, July 1981, prepared by Ford, Bacon and Davis Utah, Inc., for the U.S. Department of Energy, UMTRA Project Office, Albuquerque Operations Office, Albuquerque, New Mexico.

MK-F (MK-Ferguson), 1987a. Shiprock, New Mexico, Uranium Mill Tailings Site Remedial Action Completion Report, prepared by MK-F for the U.S. Department of Energy, UMTRA Project Office, Albuquerque Operations Office, Albuquerque, New Mexico.

MK-F (MK-Ferguson), 1987b. MK-Ferguson Construction Subcontracts, UMTRA Project Surveillance and Maintenance Plan, Shiprock, New Mexico, MK-Ferguson Company, Albuquerque, New Mexico.

NRC (U.S. Nuclear Regulatory Commission), 1991. Final Completion Report Review for the Remedial Action at the Shiprock Uranium Mill Tailings Site, Shiprock, New Mexico, NRC Division of Low-Level Waste Management and Decommissioning, Washington, D.C.

NRC (U.S. Nuclear Regulatory Commission), 1990. Final Technical Evaluation Report for the Proposed Remedial Action at the Shiprock Tailings Site, Shiprock, New Mexico, NRC Division of Low-Level Waste Management and Decommissioning, Office of Nuclear Material Safety and Safeguards, Washington, D.C.

TAC (Technical Assistance Contractor), 1993. "Survey of Water Use," conducted in January 1993 by the Technical Assistance Contractor, Jacobs Engineering Group Inc., for the U.S. Department of Energy, UMTRA Project Office, Albuquerque Operations Office, Albuquerque, New Mexico.

\section{CODE OF FEDERAL REGULATIONS}

10 CFR Part 40, Domestic Licensing of Source Material, U.S. Nuclear Regulatory Commission, (1993).

36 CFR Part 1220-1238, National Archives and Records, Subchapter B - Records Management, (1993).

40 CFR Part 192, Health and Environmental Protection Standards for Uranium and Thorium Mill Tailings, U.S. Environmental Protection Agency, (1993).

41 CFR Part 101, Federal Property Management Regulations, General Services Administration, (1993).

\section{DOE ORDERS}

Order 1324.2A, Records Disposition, September 13, 1988, Office of Information Resource Management, U.S. Department of Energy, Washington, D.C. 
Order 5000.3B, Occurrence Reporting and Processing of Operations Information, draft, September 24, 1991, U.S. Department of Energy, UMTRA Project Office, Albuquerque Operations Office, Albuquerque, New Mexico.

Drder 5480.1B, Environment, Safety and Health Program for DOE Operations, September 1986, U.S. Department of Energy, Safety Programs Division, Washington, D.C.

\section{FEDERAL REGISTER}

52 FR 36000, "Standards for Remedial Action at Inactive Uranium Processing Sites;

Proposed Rule," September 24, 1987, Federal Register, Washington, D.C.

55 FR 45591, "Custody and Long-Term Care of Uranium and Thorium Mill Tailings Disposal Sites," October 30, 1990, Federal Register, U.S. Nuclear Regulatory Commission, Washington, D.C.

\section{UNITED STATES CODE}

42 USC $\$ 7901$ et seq., Uranium Mill Tailings Radiation Control Act of 1978, November 8, 1978, Washington, D.C. 


\section{ATTACHMENT 1}

NRC CONCURRENCE AND LICENSING DOCUMENTATION 


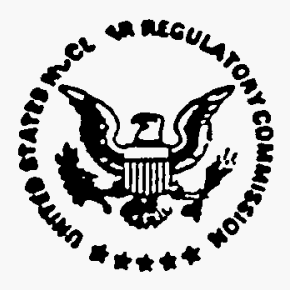

$$
\text { Nre/ums/0591-0037 }
$$

UNITED STATES

NUCLEAR REGULATORY COMMISSION

WASHINGTON, D. C. 20555

MAY O 91991

Mr. Mark Matthews, Project Manager

Uranium Mill Tailings Remedial Action

Project office

U.S. Department of Energy

Albuquerque Operations office

P.0. Box 5400 .

Albuquerque, NM 87115

Dear Mr. Matthews:

The U.S. Nuclear Regulatory Commission (NRC) staff has completed its review of the Certification Report and all associated documentation pertinent to the completed remedial action at the inactive uranium mill tailings site at Shiprock. Hew Mexico. Our review is documented in the enclosed Completion Review Report (CRR), which discusses the staff's evaluation of the completed remedial action against the previously approved plans and specifications.

Based on its review of the Certification Report and on observations during periodic site inspections, the KRC staff concurs that the Department of Energy (DOE) has performed remedial action at the Shiprock site in accordance with the approved plans and specifications and that this action complies with the Environmental Protection Agency's standards in 40 CFR Part 192, Subparts $A-C$. With the exception of characterization and cleanup of the floodpla in alluvial aquifier, remedial actions are complete for the Shiprock site. DCE has proposed deferral of selection and performance of a groundwater cleanup program at this time, and plans to handle this as part of a separate groundwater restoration program. The KRC staff, therefore, has signed the enclosed signature pages signifying its concurrence in completion of the Shiprock remedial action (other than ground-water restoration).

If you have any questions regarding this review, please contact ne at FTS 492-3439 or the NRC Project Manager, Dan Gillen, at FTS 492-0517.

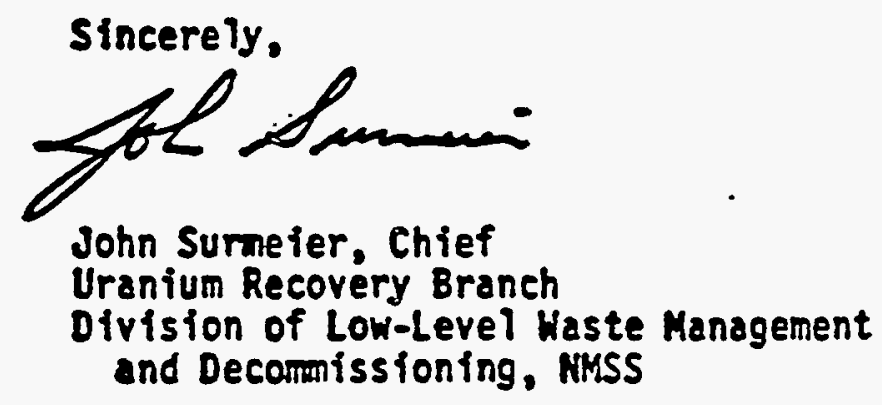

Enciosures: As stated

cc: T. Brazley, DOE Hq
M. Abrams, DOE/AT
K. Feldman, EPA
H. Begaye, Havajo Nation 


\section{U.S. DEPARTMENT OF ENERGY CERTIFICATION SUMAARY \\ for the \\ Shiprock, New Mexico, Disposaj Site}

The Uranium Mill Talings Remedial Action Project Office and the Contracts and Procurement Division for the D.S. Department of Energy certify that the Shiprock, Hew Hexico, combined processing and disposal site is complete and reets all design criteria, technical specifications, and the curface Remedial Action Plan required under Public Lav 95-604 has been met. The undersigned request thot the $0 . S$. Nuclear Regulatory Comolssion concur with this certification.

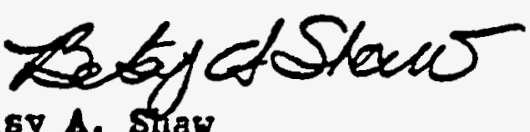

Betsy A. shaw

Chlef, Program and $R$ \& $D$ Branch Contracts and Procurement Division Contracting officer

DATE: $\quad 4 / 29 / 91$

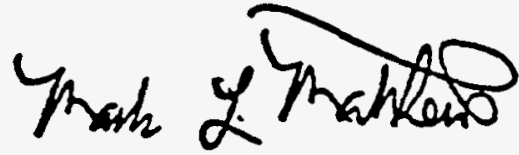

Mark L. Kat thews Project Mansger Uranfum Mlli Tailings Remedial Action Project Office

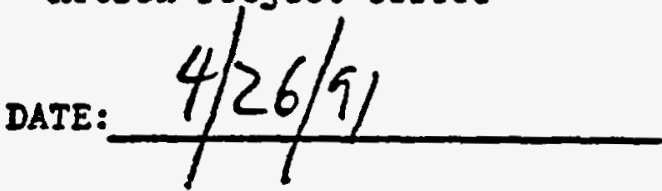

The Chief, Uranium Recovery Branch, Division of Low-Level Waste Management and Decomissioning, U.S. Nuclear Regulatory Comission hereby concurs Wth the U.S. Department of Energy's compleition of surface remedial action t the Shiprock, Hew Mexico, processing site.
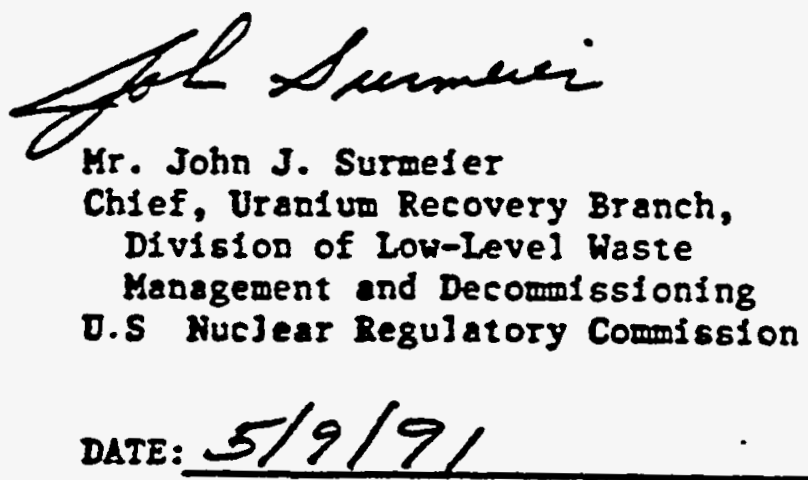
ATTACHMENT 2

SITE OWNERSHIP/CUSTODY DOCUMENTATION

(ACCESS AGREEMENT PENDING) 
ATTACHMENT 3

PERMANENT SITE FILE INDEX 


\section{LICENSING DOCUMENTATION}
A. Long-term surveillance plan (LTSP) (final)
B. Prelicensing custodial care
C. U.S. Nuclear Regulatory Commission acceptance of LTSP
D. General license takes effect

\section{DOCUMENTATION OF DOE TITLE/CUSTODY}

A. Documentation:

- State

- Federal

- Tribal

B. Legal description

C. Custodial care agreements

\section{NATIONAL ENVIRONMENTAL POLICY ACT (NEPA) DOCUMENTATION}
A. Environmental impact statement/environmental assessment
B. Record of decision/finding of no significant impact
C. Additional NEPA
D. Mitigation action plan

\section{REMEDIAL ACTION DOCUMENTATION}
A. Disposal site characterization report
B. Remedial action plan/remedial action selection report
- Concurrence pages (signed)
C. Draft/final technical evaluation report
D. Final design for construction
E. Additional design/construction documents/drawings
F. Final close-out inspection report 
G. Site certification report/package

- U.S. Department of Energy certification/summary

- Final completion report

- Final audit report

- Completion report review

- Certification pages (signed)

\section{AS-BUILT CONSTRUCTION}

- Drawings and maps

\section{PHOTOGRAPHS}
A. Construction photographs
B. Aerial photographs
C. Close-out/inspection photographs
D. Verification and orientation/initial prelicensing inspection photographs

\section{MONITORING DOCUMENTATION}
A. Active monitoring wells
B. Location of inactive (abandoned) monitor wells
C. Monitoring station records
D. Monitoring reports
E. Programmatic procedures

\section{AGREEMENTS}
A. Interagency
B. Individual/private
PDCC SITE FILE INDEX 
ATTACHMENT 4

SITE INSPECTION PHOTO LOG 


\section{SITE INSPECTION PHOTO LOG}

Site: Site Activity:

Date: Time of Day: From to

Weather Conditions:

Roll Number: Film Type: Number of Exposures

Photo Number

Location

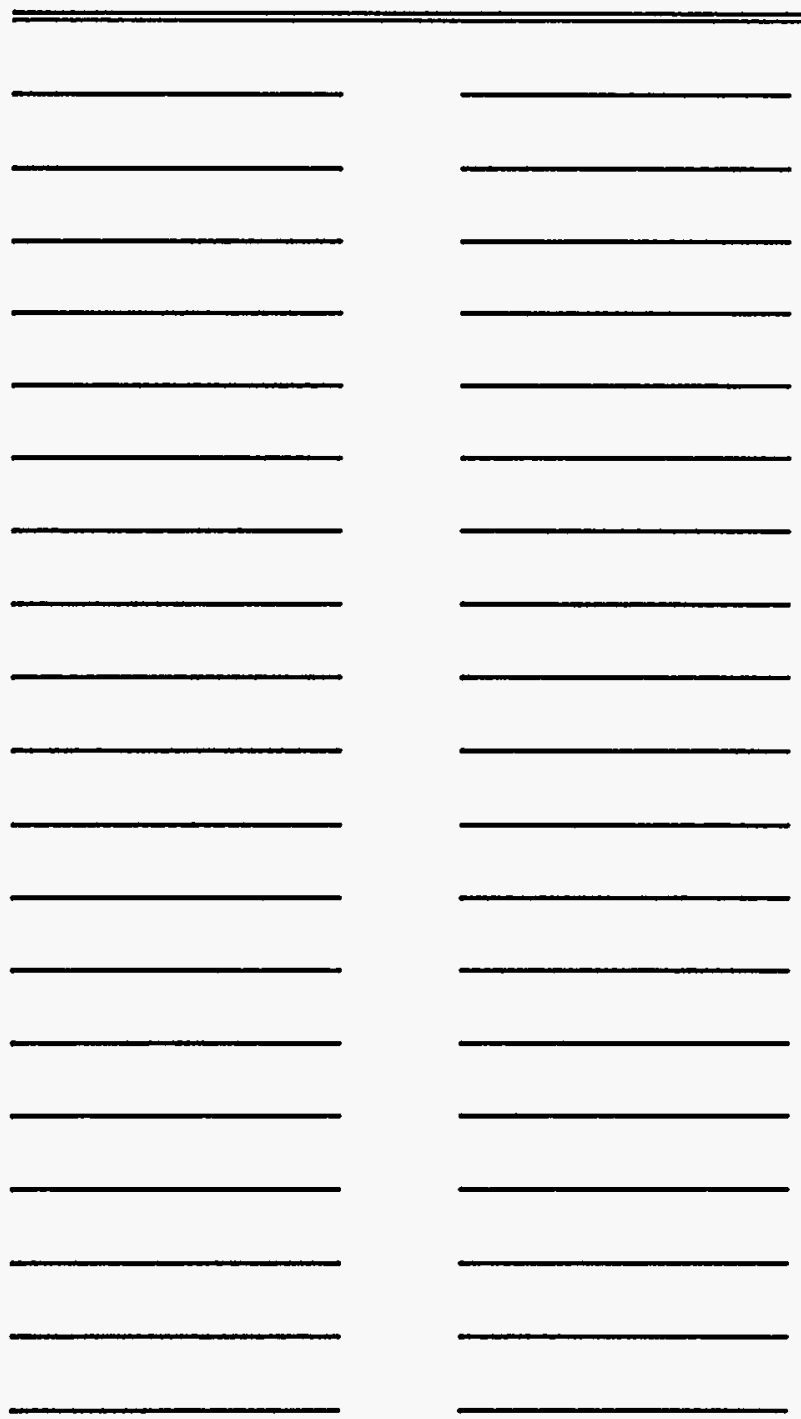

Description 


\section{SITE INSPECTION PHOTO LOG (CONT.)}

\section{Site}

Date

Photo Number

Location

Description

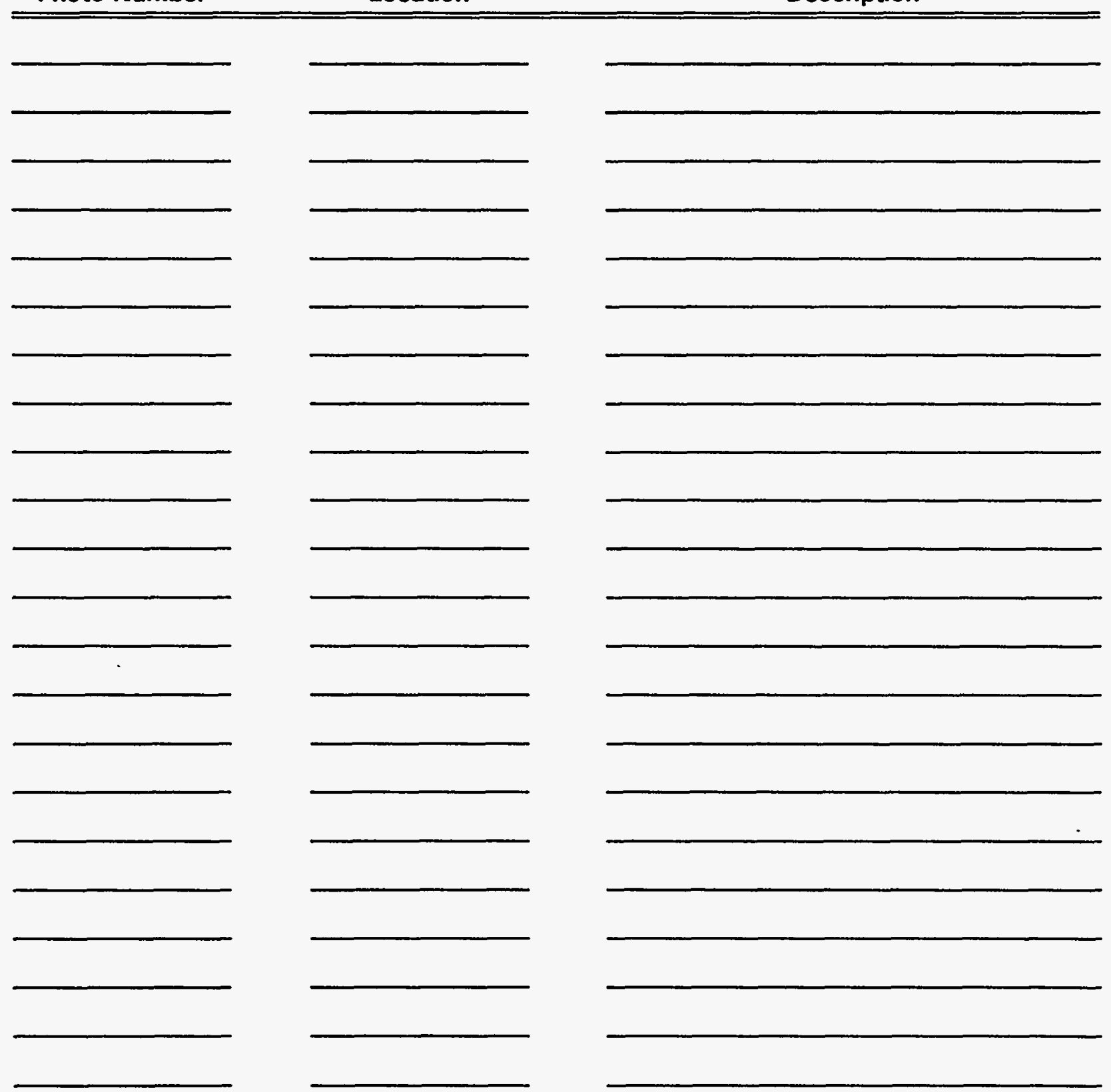




\section{SITE INSPECTION PHOTO LOG (CONT.)}

Photo Number

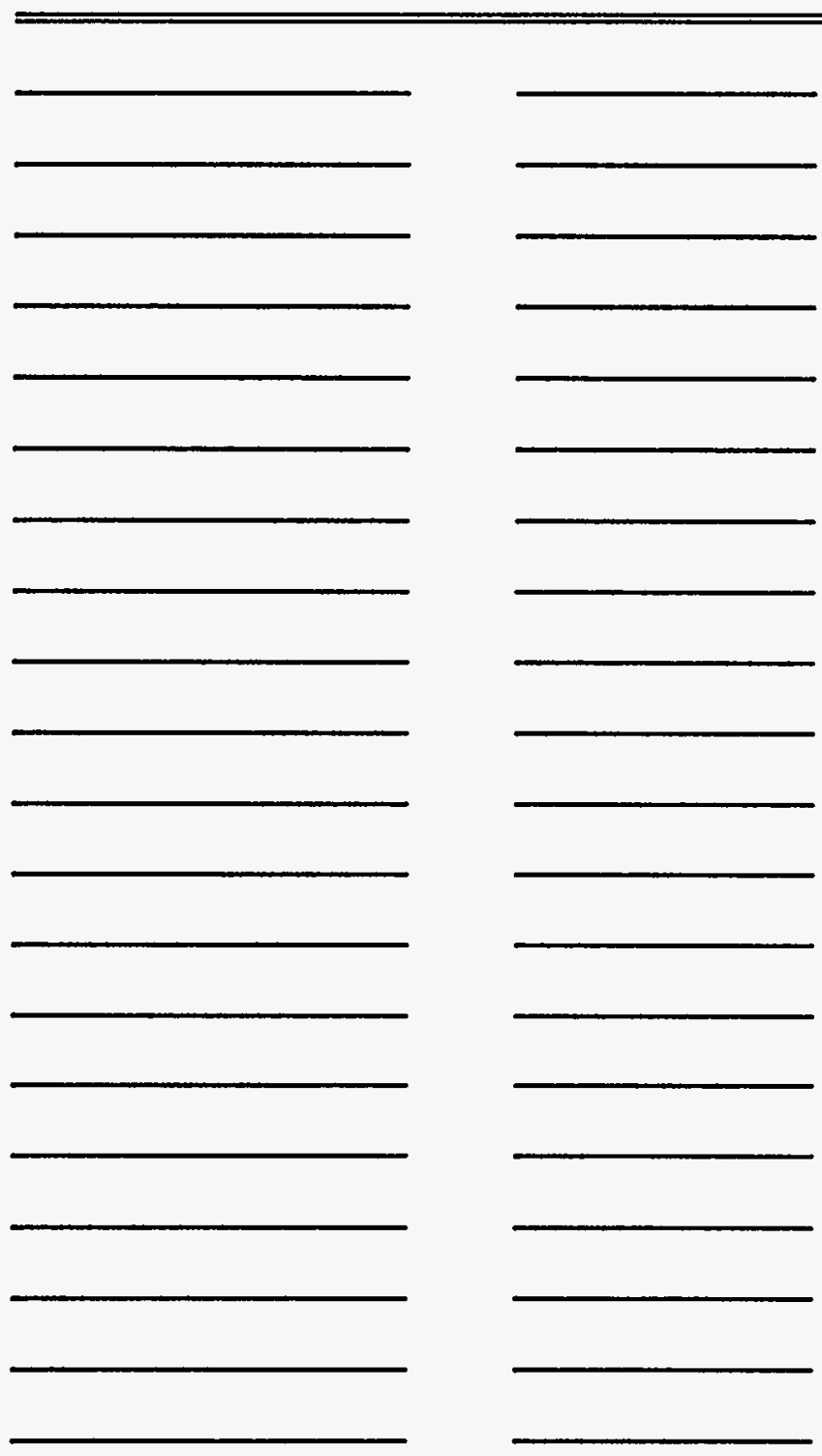

Photographer:
Description 
ATTACHMENT 5

INITIAL SITE INSPECTION CHECKLIST 


\section{SITE INSPECTION CHECKLIST FOR THE SHIPROCK, NEW MEXICO URANIUM MILL TAILINGS DISPOSAL SITE}

Date of Last Inspection:

Reason for Last Inspection:

Responsible Agency ${ }^{1}$ : DOE Grand Junction Projects Office

Address: P.O. Box 2567, Grand Junction, Colorado 81502-2567

Responsible Agency Official:

Inspection Start Date and Time:

Weather Conditions at Site:

Inspection Completion Date and Time:

Chief Inspector:

Name

Assistant Inspectors:
Title Organization

Name Title Organization

Name

Title

Organization

\section{A. GENERAL INSTRUCTIONS}

1. All checklist items must be completed and detailed comments made to document the results of the site inspection. The completed checklist is part of the field record of the inspection. Additional pages should be used, as necessary, to ensure that a complete record is made. Attach the additional pages and number all pages upon completion of the inspection.

2. Inspectors are to provide an up-to-date résumé or vitae for inclusion in the inspection report.

3. Any checklist line item marked by an " " that is checked by an inspector must be fully explained or an appropriate reference to previous reports provided. The purpose of this requirement is to provide a written explanation of inspector observations and the inspector's rationale for conclusions and recommendations. Explanations are to be placed on additional attachments and cross-referenced appropriately. Explanations, in addition to narrative, will take the form of sketches, measurements, and annotated site atlas overlays.

${ }^{1}$ Responsibility for site inspections assigned by DOE UMTRA Project Office, Albuquerque, to DOE Grand Junction Projects Office, November 6, 1990. 
4. The site inspection is a walking inspection of the entire site, including the perimeter and sufficient transects as specified in Section 6.4.2, to be able to inspect the entire surface and all features specifically described in this checklist. Every monument, site marker, sign, and erosion control marker will be inspected.

5. A set of color print $35-\mathrm{mm}$ photographs is required. Sufficient photographs will be taken to compare to baseline photographs and determine if there are any significant differences in site appearance. In addition, all anomalous features or new features (such as changes in adjacent area land use) are to be photographed. A photo log entry will be made for each photograph taken.

6. Field notes taken to assist in completion of this checklist will become part of the inspection record. No form is specified; the field notes must be legible and in sufficient detail to enable review by succeeding inspectors and the responsible agency.

B. PREPARATION (to be completed prior to site visit)

1. Review licenses (including Long-Term Surveillance and Maintenance Plan).

2. Obtain site as-built plans with the following information:

a. Adjacent off-site features and land use; fences, gates, and signs; access roads and paths.

b. Survey monuments, boundary markers, site markers, aerial photo ground controls, ground photo locations.

c. Site drainage and diversion channels.

d. Planned inspection transects and vegetation cover.

e. Others.

3. Review previous inspection reports.

a. Were anomalies or trends in modifying processes detected on previous inspections?

b. Was a Phase II inspection conducted?

c. Was custodial maintenance performed?

d. Was contingency repair work done as a result of the Phase II inspection? 
4. Review site custodial maintenance and contingency repair records.

a. Has site contingency repair resulted in a change from as-built conditions?

b. Are revised as-builts available that reflect contingency repair changes?

5. When necessary, obtain entry approval to adjacent property (attach signed access agreement).

6. Review aerial photos if taken since last inspection.

For each set, enter date taken, scale, and if interpreted.

Set

Date

Scale

Interpreted

$\underline{\mathrm{Y}} \quad \underline{\mathrm{N}}$

1.

2.

3.

7. Were any of the following suggested by examination of aerial photographs? (If yes, give photo set date and indicate if item noted by interpreter or inspector):

a. Intrusion by man?

b. Intrusion by animals?

c. Channelized erosion on slopes?

d. Change in area drainage?

e. Landslides?

f. Creep on slopes?

g. Obstruction of diversion channels?

h. Bank erosion of diversion channels?

i. Seepage? 


\section{j. Cracking?}

k. Change in vegetative cover?

I. Displacement of fences, site markers, boundary markers, or monuments?

$\mathrm{m}$. Change in adjacent land use?

n. Evidence of tailings exposure or transport?

8. From as-builts, or subsequent inspection reports, note distance and azimuth from designated site location, such as a monument, to adjacent off-site features that could eventually affect integrity of site.
Off-site feature
Site monument no.
Distance
Azimuth

1.

2.

3.

9. Assemble and check out the following equipment, as needed, to conduct inspections:
a. Cameras, film, and miscellaneous support equipment.
b. Binoculars.
c. Tape measure.
d. Optical ranging device.
e. Compass.
f. Photo scale stick.
g. Erasable board.
h. Plant press, plastic bags for vegetation.
i. Keys to locks.
j. Bolt cutters.
k. Hand lens.
I. Clipboard.
m. Others. 


\section{SITE INSPECTION}

1. Adjacent off-site features [within 0.25 mile $(0.4 \mathrm{~km})$ of site boundary]

a. Have there been any changes in use of adjacent areas (grazing, construction, agriculture)?

b. Are there any new roads or trails?

c. Has there been a change in the position of nearby stream channels?

d. Has there been headward erosion of nearby gullies?

e. Are there new diversion channels?

f. Others?

2. Access roads and paths, fences, gates, and signs.

a. Is there a break in the fence?

b. Have any posts been damaged or their anchoring weakened?

c. Is there evidence of erosion or digging beneath the fence?

d. Do any of the gates show evidence of tampering or damage?

e. Is there any evidence of human intrusion?

f. Is there any evidence of large animal intrusion?

g. Have any signs been damaged or removed? (Number of signs replaced:

h. Are access roads and paths passable?

i. Others? 
3. Monuments and other permanent features.

a. Have the survey or boundary monuments been defaced or disturbed?

b. Have the site markers been disturbed by man or natural processes?

c. Do natural processes threaten the integrity of any monument or site marker?

d. Others?

4. Crest.

a. Is there evidence of uneven settling?

(depressions, scarps)

b. Is there cracking?

c. Has the outer cover layer been breached?

d. Is there evidence of erosion?

1) By water? (rills, rivulets)

2) By wind? (pedestal rocks, ripple marks)

e. Is there evidence of animal burrowing?

f. Others?

5. Slopes.

a. Is there evidence of gradual downslope movement (creep)? (terraces, deflection of plants)

b. Is there cracking?

c. Can depressions or bulges on the slope be seen?

d. Has the outer cover layer been breached? 
e. Is there evidence of erosion:

1) By water?

2) By wind?

f. Has water runoff become channelized? (rivulets, gullies)

g. Is there evidence of seepage? (moisture, color, vegetation)

h. Is there evidence of animal burrowing?

i. Is there evidence of deterioration of riprap or gravel cover?

j. Others?

6. Periphery (within site boundaries).

a. Is there evidence of seepage such as wet areas or localized change of vegetation?

b. Is there evidence of sediment transport from the tailings pile by water or wind?

c. Is the drainage as described in the as-builts?

d. Others? Burrowing animals; erosion.

7. Diversion channels.

a. Is there evidence of bank erosion?

b. Has the integrity of riprap structures been disturbed by people or natural processes?

c. Is there evidence of channel erosion?

d. Is there evidence of sedimentation in the channel?

e. Is the channel obstructed in any way? 
f. Is there any evidence that the diversion channels are not performing their function?

g. Others?

8. Photography.

a. Have all photos required by the site atlas photo overlay been taken?

b. Has a photo log sheet been prepared for each roll of film exposed?

c. Number of rolls of film exposed:

d. Number of frames per roll:

e. Others?

\section{FIELD CONCLUSIONS}

1. Is there an imminent hazard to the integrity of the tailings pile? (Immediate report required)

Person

Agency to whom report made:

2. Are more frequent Phase I inspections required?

3. Are existing contingency repair actions satisfactory?

4. Is a Phase $1 /$ inspection required?

5. Is a contingency report or custodial maintenance required?

6. Rationale for field conclusions are documented as the text of this report. 


\section{E. CERTIFICATION}

I have conducted a prelicensing inspection of the Shiprock uranium mill tailings site in accordance with the procedures of the license (includes the site surveillance plan) as recorded on this checklist, attached sheets, field notes, photo log sheets, and photos.

Chief Inspector's Signature

Title
Printed Name

\section{Date}

(Stamp or Seal) 
ATTACHMENT 6

\section{AGENCY NOTIFICATION AGREEMENTS}




\section{Alber R. Chemoff \\ . UMTRA Projeet Manager \\ Attention: Mike Abrams \\ U.S. Deparment of Energy \\ UMTRA Project Office \\ 5301 Central Avende, NE, Suite 1720 \\ Albuquerque, New Mexico 87108}

Dear Mr. Chermoff:

This letrer is to concur with the U.S. Department of Energy (DOE) request for notification as set forth in the DOE's letter of (date) HOY : : 1992. As requested in your letter, this office will contact the DOE's Grand Junetion Projects Office if a dam failure or a large-scale relesse due to a flood event greater than the outlow capseity of the Navajo Dam is imeninent.

Sixcerely,

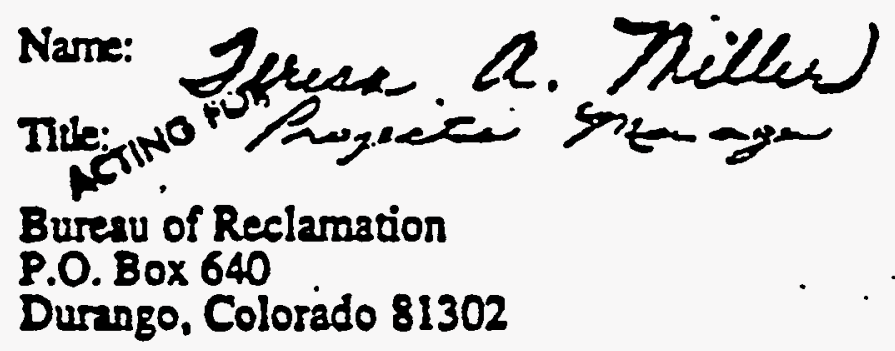




\author{
Abort R. Cnemoil \\ UMTMA Projod Manegor \\ Attantlon: Milke Abrams \\ U.B. Dopartmenl of Enorgy \\ UMTRM Proleot OHloe

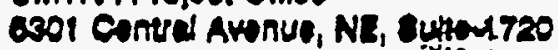 \\ Abuguarques, Now Maxico oftos $=$ \\ Dax Mi. Chemeft:
}

This bollor to to concur with the U.3. Departmant of Energy (DOE) requeat for netfleation as set forth in the DOE's tetter of (date) Novembar 20, 1022. As requested in you! lonter. this offies will oomact the DOE's Grand Junetion Projects Otrice H amything out of the ordinary is obenrved by our etafi di ieporrod to our oflice. Wo will nolify you ae immedininly as possible at the DOE Grand Junflon Projects Olitis's 24-ticut phome line at (303) 2486070.

Additlonally, we will provide coneurrent rotfication to Bornadine Martin in the Nerrajo UMTRA Prolect Offies of (602) B71-6359.

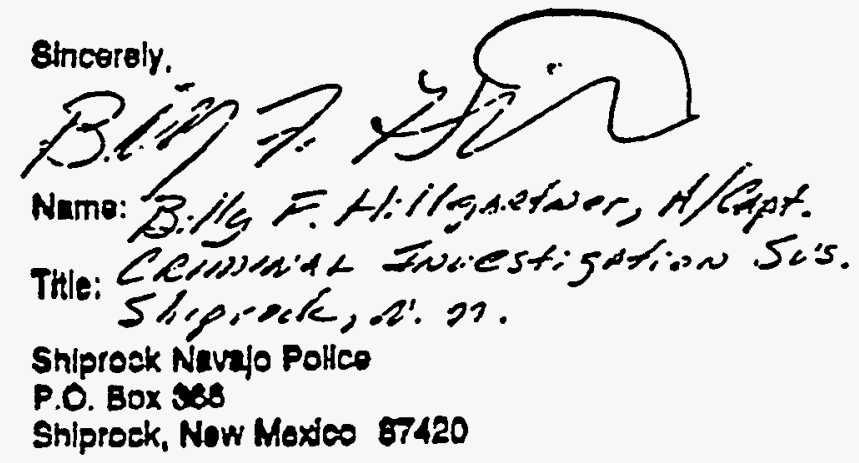

F:

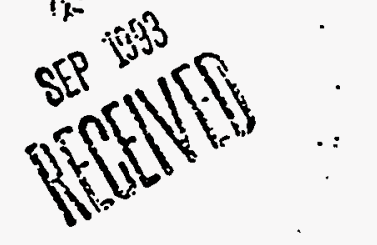




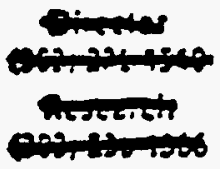

U.S. Geologieal Survey

Box 23046, DFC, 4S967

Denver, Colordo USA

Telex: (HUTCO) S106014123ESL UD

FAX: (303)

$275 \cdot 8480$
Operations

(303) …223-8500

- QED

(c)0) 358-2663

December 14, 1992

Albert R. Chernose

UISTR Project Hanager.

0.5. Department of Inergy

Uranium M111 Talilngs Remedial detion

Project office

5301 Central Ave. NE, Sulte 1720

Albuguergue, RAS 87108

Dear kr. Chernote:

This letter is to corifirm that the Dos Grand Junetion projects Office has been added to our notification list for earthguakes near the following sites:,

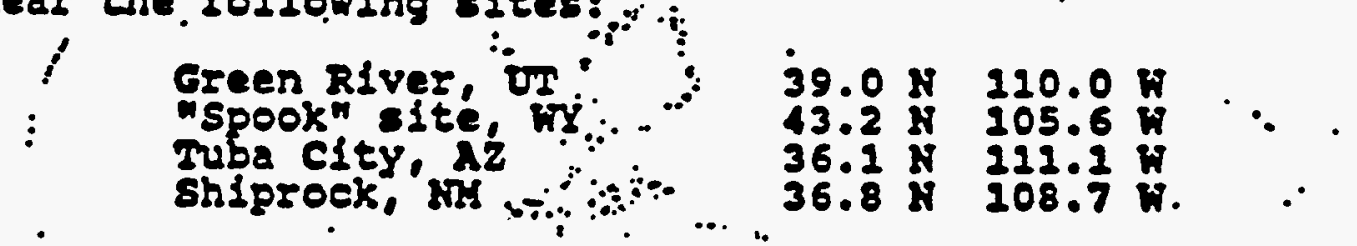

We have entered the following selection criteria into our notification program:

2. Any earthguake of magnitude 3.0 or greater, within 0.3 degrees (about 20 miles) of any site shown above, or

2. Any earthquake of magnitude 5.0 or greater, within 1.0 degrees (about 70 miles) of any site shown above.

Hote that these criteria are alightly different than the ones you requested, but we believe that they will still neet your needs. It was not possible to Include your first eriterion (any eartheguake centered within a 9-mile radius of a site) for two reasons. First, this offlce does not work events that have aagnitudes less than 2.5 on the Richter scale, uniess.someone has reported that the earthguake was felt. Since the Richter scale 18 logarithmic, earthguakes of nagnitude 0 or even negative $(-1.3,-2.3$, etc) are possible, but with the station distribution we have $1 t$ would not be possible for us to locate them. Gecond, the 9 -mile radius, or about 0.1 degrees, is omaller than the location ersor which ray occur for the preilininary locations we will be reporting to you. In Eact, our preliminary locations Whlch will be reported to the Grand Junetion projects office will be reported only to the nearest tenth of a degree of latitude and longltude. 
For the oltes shown above, we belleve that we can locate earthguakes reliably that are above a threshold of magnitude 3.0 . We also ouggest that if any of your personnel at any of these sites feel an carthguake. they should cal1 our offlce at (303) 273-8500 arid our duty geophyslcists w111 check, the cvent for them. Hote that after normal duty hours, there is a reoording on this number giving the bome phone numbers of the two geophyslelsts on duty.

We have reduced the pagnitude threshold for the last criterlon from 6.2 to 5.0 and have Increased the maximun radius $\mathrm{from} 40 \mathrm{miles}$ to 70 iles because large earthouakes are not polnt sources but can have rupture Iengths of elgnifleant slze. For example, the Ianders, Callfornia carthoguake on June 28 (magnitude 7.6 ) had a jupture length of vore than 40 diles and the Great Xlaska earthouake of 1964

(magnitude 9.2 ) had a rupture length of about 400 miles. The location ve compute for an earthoguake is the hypocerter - the place where the earthguake starts. Usualiy an arthquake wiII rupture farther in one direction than others from the hypocenter. Ihls means that a magnitude 8 carthosuake with a hypocenter 60 miles away from one of your sites may In inct have ruptured directly through the site, depending on the orientation of the gault.

If you have any questlons about these criteria, please give us a cal1.

sincerely,

Eruce 2. Treygum

Bruce H. Presgrave

Geophysicist 
P.O. BOX 9025

Albuquerque, New Hexico 87119-9025

December 3, 1992

Mr. Albert R. Chernoff

UMTRA Project Manager

U.S. Department of Energy

UMTRA Project Office

5301 Central Avenue, Suite 1720

Albuquerque, New Mexico. 87108

Attention Mr. Mike Abrams

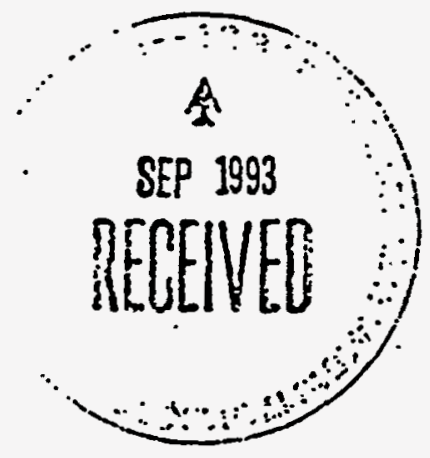

Dear Mr. Chernoff:

Presently, the National Weather Service (NWS) depends on several vehicles for dissemination of severe weather watches and warnings. When we issue a warning for San Juan County, we compose and transmit the warning on the Automation of Field Services (AFOS) computer system. This allows the warning to be

disseminated further via the GTE/Contel weather wire service, which also feeds the Associated Press and a host of other dissemination services. Second, we read the warning on the National Oceanic and Atmospheric Administration Weather Radio (NWR). Third, we read the warning on the NAWAS circuit.

Since my staff's workload is especlally overbearing during severe werther, and we have lost generally 20 percent of our personnel over the past decade and are expecting to lose more, I would prefer not to add this additional duty to our operations. Additionally, we have no weather station or cooperative weather observer at the Shiprock disposal site. However, I would be glad to help you with your project in another way. I would like to recomend the following possibilities for your operation:

"(1) If you require a hard copy of watches, warnings, statements, or forecasts, you can subscribe to the GTE/Contel weather wire. You can obtain a free Information package by calling GTE/Contel at 1-800-633-2340.

(2) If you don't need hard copies but want to receive warnings and have access to other weather Information, your Shiprock disposal site can purchase a NOAA Weather Radio recelver with a warning alarm feature for about \$40. The radio can be turned off and st1ll sound an alarm whenever a warning has been Issued for San Juan County. The alarm would be activated via our transmission. from the state microwave network at a frequency of $162.475 \mathrm{MHz}$.

(3) Anytine you believe that severe weather may have occurred in the Shiprock area, feel free to call us; and we will give you any reports we have. 
$\because$

Presently, San Juan County (11ke nearly all of New Mexico) has no weather radar coverage. Consequently, severe weather often goes undetected. However, severe weather reports that come to our attention after the fact are included in the "Storm Data' published monthly by the National Climatic Data Center in Asheville, North Carolina. The problem of inadequate radar coverage for San Juan County will be diminished with the advent of the new NEXRAD, WSR-88D doppler system at Albuquerque in 1994. In the mean time, I believe that option number three listed above would offer the best approach.

Please do not hesitate to call if you have questions or would Iike to discuss this watlar further.

Sincerely, ล.? : $: \cdots$

Charlie A. Liles Area Manager 


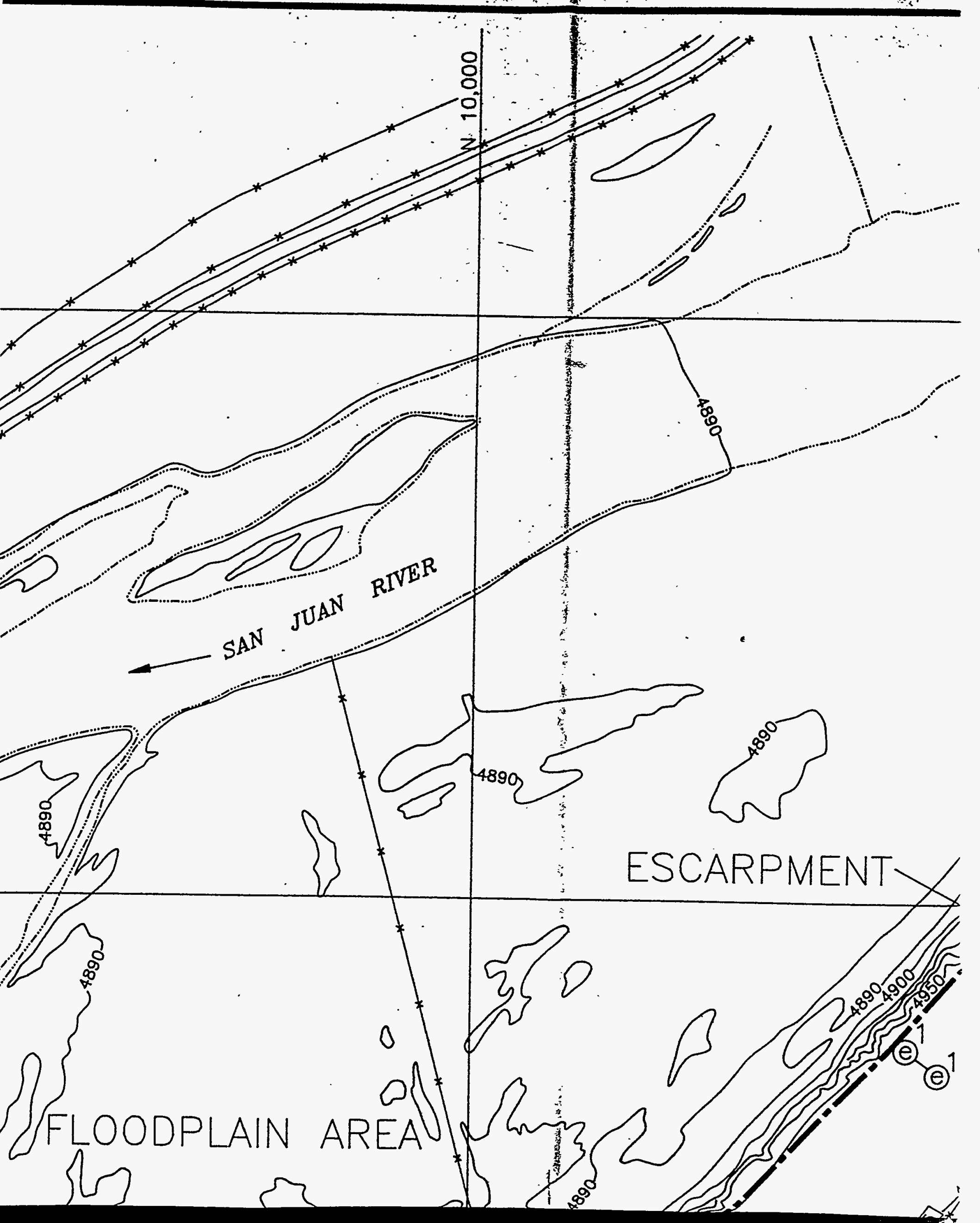


- SAN JUAN RIVER

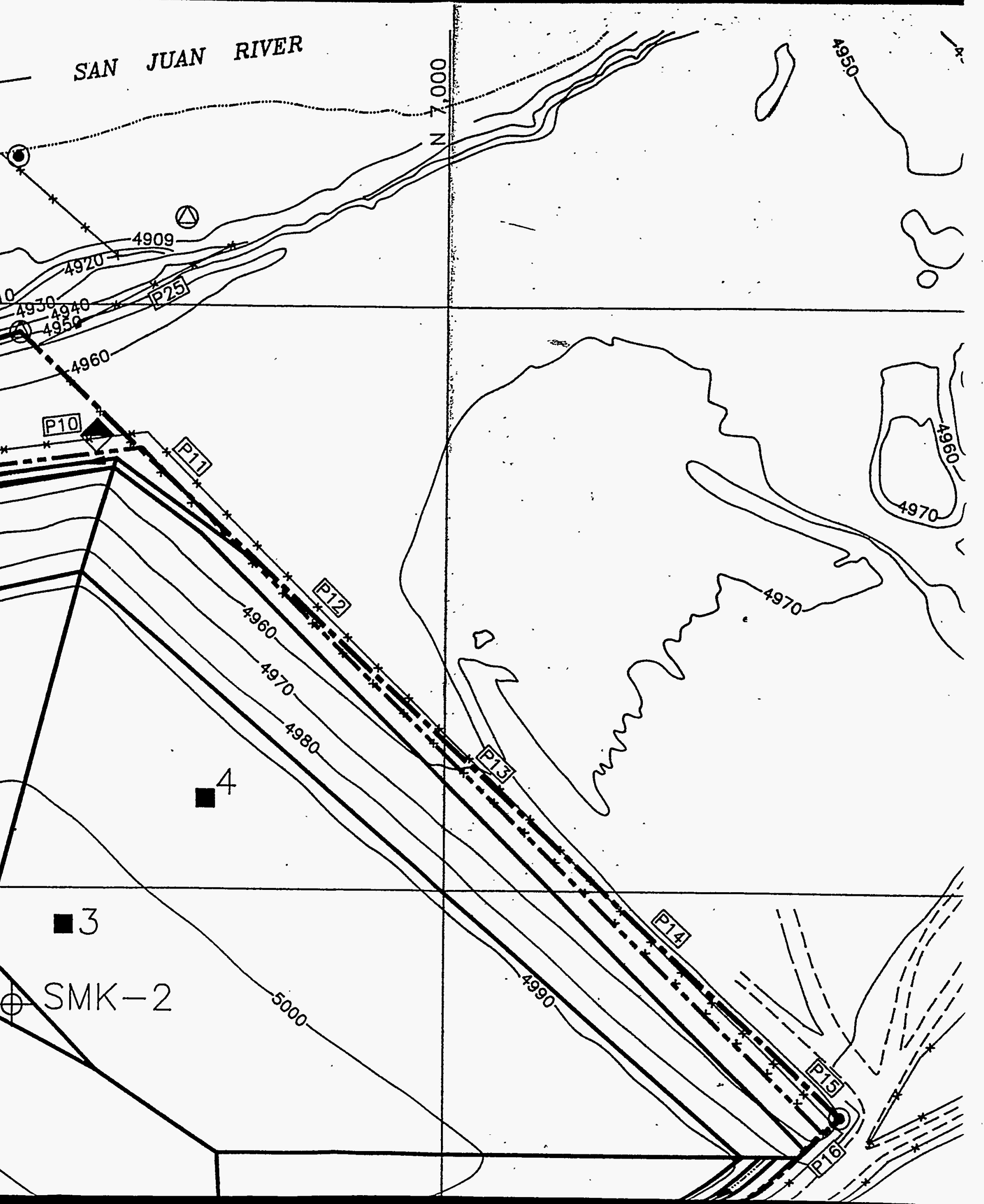





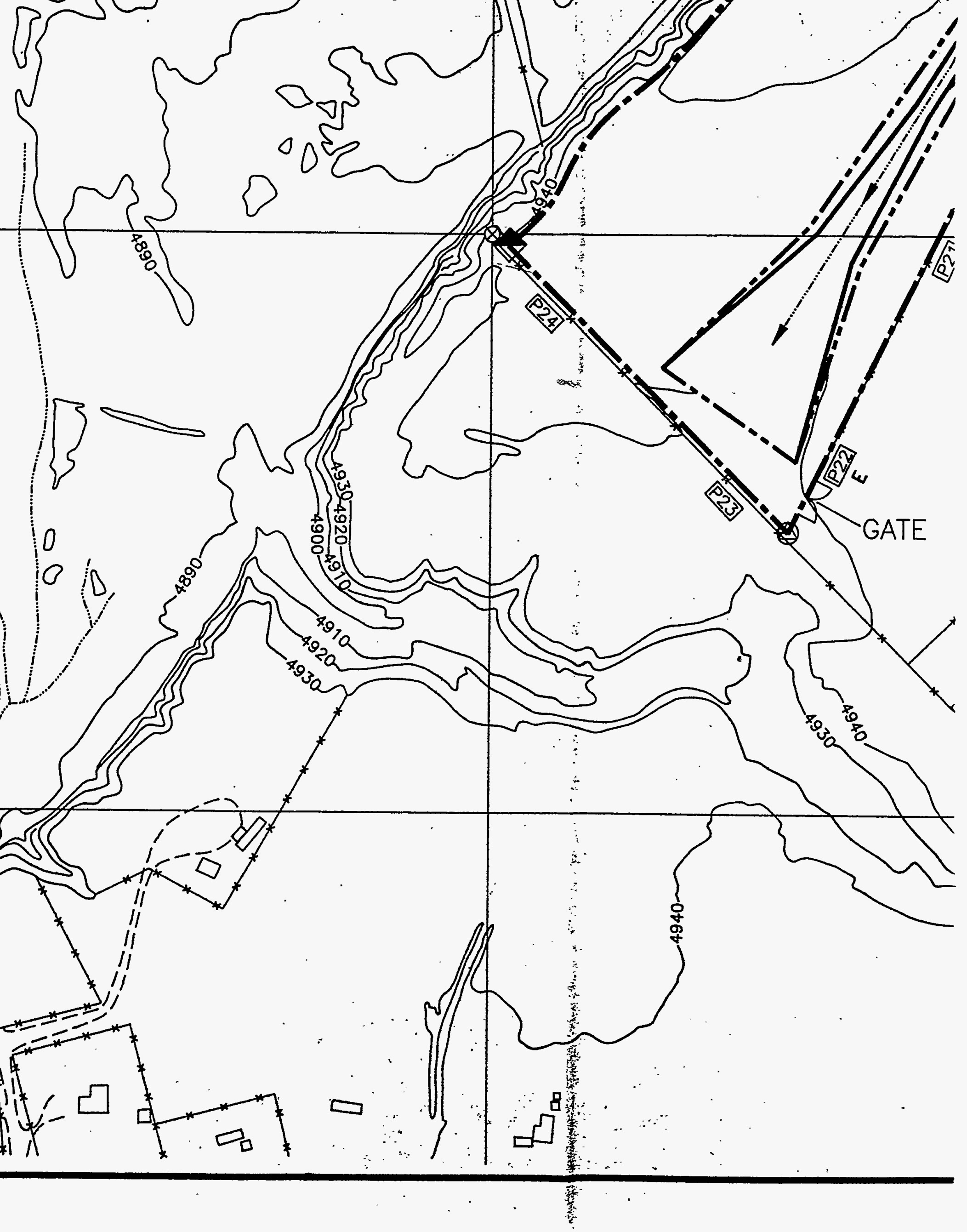




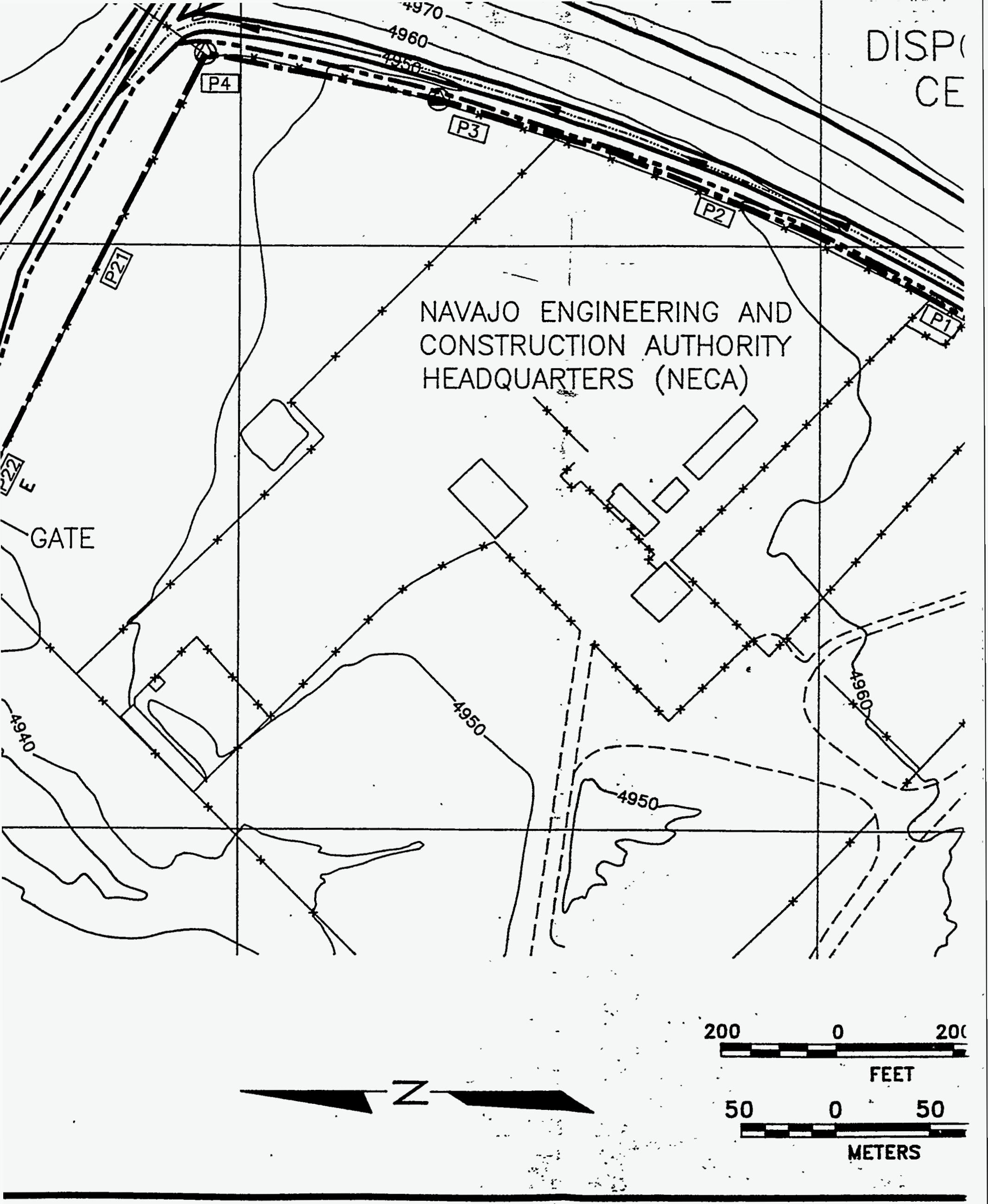




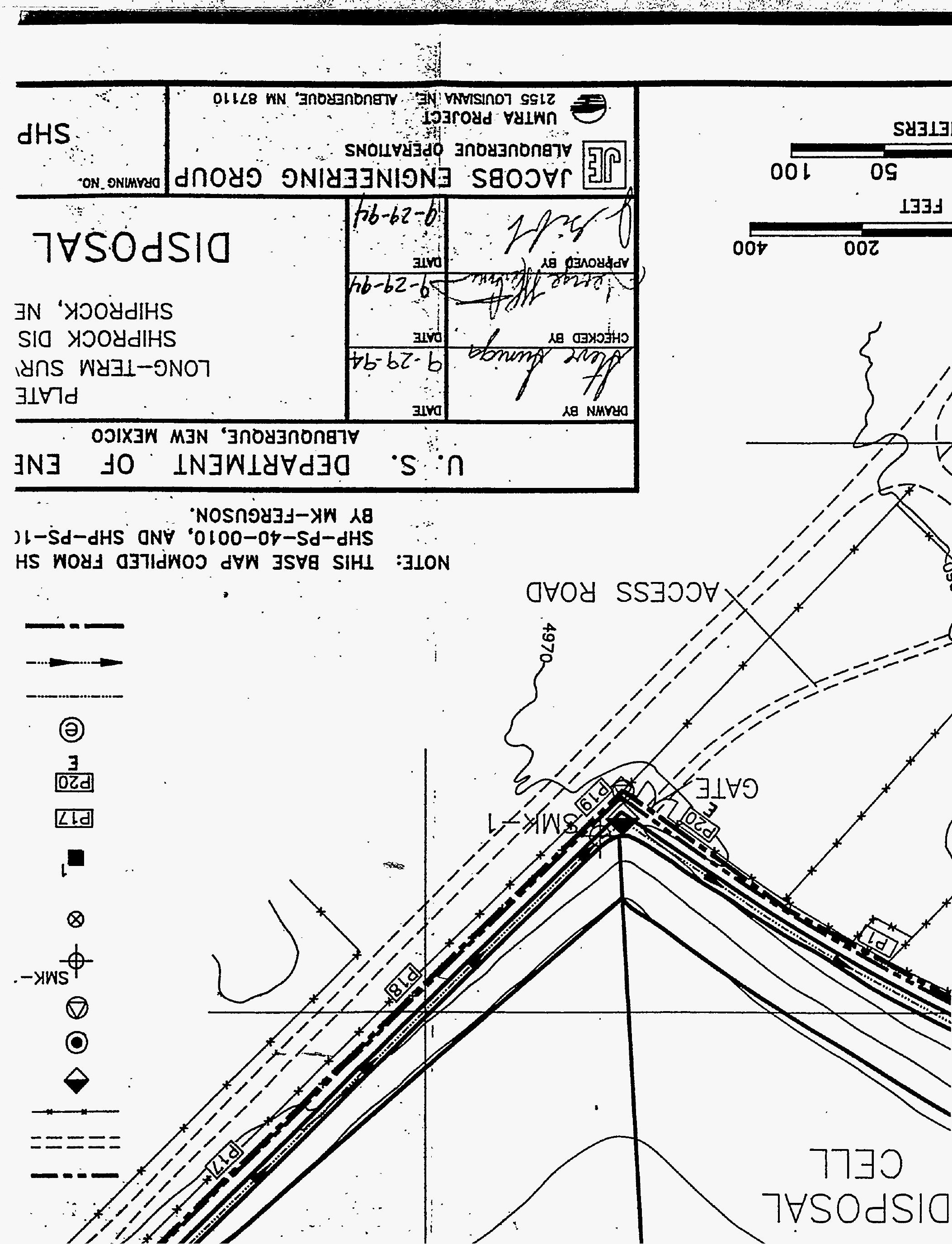


